A Food and Agriculture Organization of the United Nations

The right to water for food and agriculture 



\section{The right to water for food and agriculture}

by

Elisa Morgera, Elaine Webster, Graham Hamley, Francesco Sindico, Jill Robbie, Stephanie Switzer, Thierry Berger, Pedro Pablo Silva Sànchez, Mitchell Lennan, Renee Martin-Nagle, Elsa Tsioumani, Ruby Moynihan and Antonia Zydek

for

the Development Law Service

Food and Agriculture Organization of the United Nations (FAO),

Rome, 2020 
Required citation:

Morgera, E., Webster, E., Hamley, G., Sindico, F., Robbie, J., Switzer, S., Berger, T., Silva Sànchez, P.P., Lennan, M., Martin-Nagle, R., Tsioumani, E., Moynihan, R. \& Zydek, A. 2020. The right to water for food and agriculture. Rome, FAO. https://doi.org/10.4060/ca8248en

The designations employed and the presentation of material in this information product do not imply the expression of any opinion whatsoever on the part of the Food and Agriculture Organization of the United Nations (FAO) concerning the legal or development status of any country, territory, city or area or of its authorities, or concerning the delimitation of its frontiers or boundaries. The mention of specific companies or products of manufacturers, whether or not these have been patented, does not imply that these have been endorsed or recommended by FAO in preference to others of a similar nature that are not mentioned.

The views expressed in this information product are those of the author(s) and do not necessarily reflect the views or policies of FAO.

ISSN 1014-6679 (Print)

ISSN 2664-5106 (Online)

ISBN 978-92-5-132301-4

(C) FAO, 2020

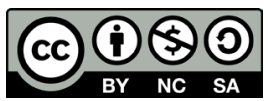

Some rights reserved. This work is made available under the Creative Commons Attribution-NonCommercialShareAlike 3.0 IGO licence (CC BY-NC-SA 3.0 IGO; https://creativecommons.org/licenses/by-nc-sa/3.0/igo/ legalcode).

Under the terms of this licence, this work may be copied, redistributed and adapted for non-commercial purposes, provided that the work is appropriately cited. In any use of this work, there should be no suggestion that FAO endorses any specific organization, products or services. The use of the FAO logo is not permitted. If the work is adapted, then it must be licensed under the same or equivalent Creative Commons licence. If a translation of this work is created, it must include the following disclaimer along with the required citation: "This translation was not created by the Food and Agriculture Organization of the United Nations (FAO). FAO is not responsible for the content or accuracy of this translation. The original [Language] edition shall be the authoritative edition."

Disputes arising under the licence that cannot be settled amicably will be resolved by mediation and arbitration as described in Article 8 of the licence except as otherwise provided herein. The applicable mediation rules will be the mediation rules of the World Intellectual Property Organization http://www.wipo.int/amc/en/ mediation/rules and any arbitration will be conducted in accordance with the Arbitration Rules of the United Nations Commission on International Trade Law (UNCITRAL).

Third-party materials. Users wishing to reuse material from this work that is attributed to a third party, such as tables, figures or images, are responsible for determining whether permission is needed for that reuse and for obtaining permission from the copyright holder. The risk of claims resulting from infringement of any thirdparty-owned component in the work rests solely with the user.

Sales, rights and licensing. FAO information products are available on the FAO website (www.fao.org/ publications) and can be purchased through publications-sales@fao.org. Requests for commercial use should be submitted via: www.fao.org/contact-us/licence-request. Queries regarding rights and licensing should be submitted to: copyright@fao.org.

Cover Photo: (C) Jialiang Gao 


\section{Contents}

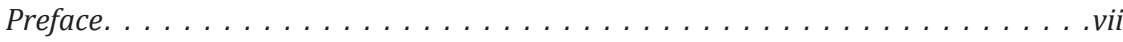

Acknowledgements . . . . . . . . . . . . . . . . ix

Acronyms and abbreviations . . . . . . . . . . . . . . . xi

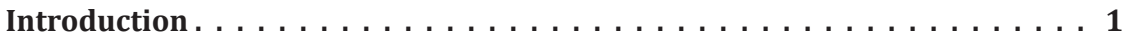

1. The human right to water $\ldots \ldots \ldots \ldots$

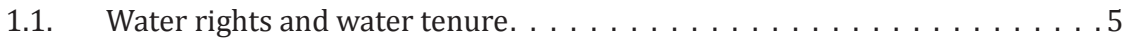

1.2. The emergence of a human right to water $\ldots \ldots \ldots \ldots \ldots$

1.3. General Comment No. 15 on the normative content of the right to water. . 11

1.4. International obligations arising from the right to water $\ldots \ldots \ldots \ldots 14$

1.5. General obligations. . . . . . . . . . . . . . . . . . . 14

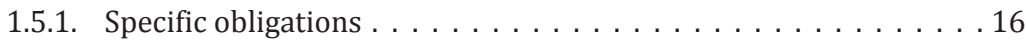

1.5.2. Procedural obligations . . . . . . . . . . . . . 16

1.5.3. International cooperation . . . . . . . . . . . . . 18

1.5.4. Responsibility of non-state actors . . . . . . . . . . . . 19

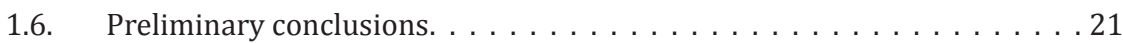

2.1. Insights and challenges from the perspective of the right to food. . . . . 25

2. The human right to water for food and agriculture . . . . . . . . .25

2.1.1. Insights from the High Level Panel of Experts on water for food security and nutrition . . . . . . . . . . . . . . . . . . 29

2.2. Groups requiring special consideration . . . . . . . . . . . . 31

2.2.1. Women. . . . . . . . . . . . . . . . . 32

2.2.2. Indigenous peoples . . . . . . . . . . . . . . 33

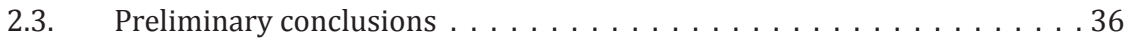


3. Insights from other relevant areas of international law . . . . . . . . 39

3.1. International investment law $\ldots \ldots \ldots \ldots \ldots \ldots$

3.2. International trade law . . . . . . . . . . . . . . . . . . 42

3.2.1. Water efficient agriculture - the role of subsidies $\ldots \ldots \ldots 43$

3.2.2. Process and production methods . . . . . . . . . . . 44

3.2.3. Bulk water transfers . . . . . . . . . . . . . . . . . . . 46

3.2.4. Trade and virtual water . . . . . . . . . . . . . . . 48

3.3. International climate change law . . . . . . . . . . . . . . . . . 50

3.4. International biodiversity law $\ldots \ldots \ldots \ldots \ldots \ldots \ldots \ldots \ldots \ldots \ldots$

3.4.1. General guidance $\ldots \ldots \ldots \ldots \ldots 7$

3.4.2. Specific guidance concerning indigenous peoples and local communities. . . . . . . . . . . . . . . . . . . 59

3.5. International law on transboundary watercourses $\ldots \ldots \ldots \ldots$. . . 62

3.5.1. United Nations Convention on International Watercourses . . . . 63

3.5.2. United Nations Economic Commission for Europe Water Convention . . . . . . . . . . . . . . . . . . . . 66

3.5.3. United Nations Economic Commission for Europe Protocol on Water and Health . . . . . . . . . . . . . 68

3.5.4. Draft Articles on Transboundary Aquifers . . . . . . . . . . . 69

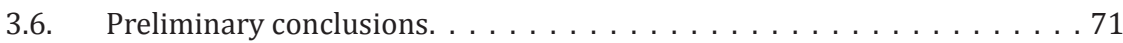

4. Implications of the right to water for food and agriculture . . . . . .77

4.1. Human rights-based approach $\ldots \ldots \ldots \ldots \ldots \ldots 7$

4.2. Integrated water resources management $\ldots \ldots \ldots$. $\ldots \ldots$

4.3. A human rights-based approach to integrated water resource

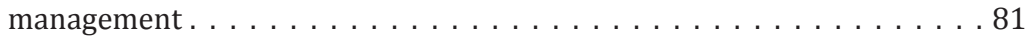

4.3.1. The interaction between the human right to water, water rights and land tenure . . . . . . . . . . . . 82

4.3.2. Considerations related to customary land and water rights . . . . 85

4.4. Relevant examples in national law . . . . . . . . . . . . . 87

4.5. Implications for reviewing (and reforming) national law. . . . . . . . 94 
Conclusion

References. . . . . . . . . . . . . . . . . . . . . . . . . . 104

Literature . . . . . . . . . . . . . . . . . . . . . . . . 104

Legally-binding international instruments . . . . . . . . . . . . 119

Non-legally-binding international instruments . . . . . . . . . . . . 123

National legislation . . . . . . . . . . . . . . . . . . . . 128

International case law . . . . . . . . . . . . . . . . . . . . . . 129

National case law . . . . . . . . . . . . . . . . . . 130 



\section{Preface}

The right to water is a self-standing right inextricably connected to the right to an adequate standard of living, and is understood to be also inherent in the right to health and the right to life. The right to water and the right to food are intimately connected and therefore, these rights are expected to mutually support the realization of one another with a view to contributing to an adequate standard of living.

The scope of the human right to water has mostly been understood to encompass domestic uses, for drinking and for hygiene. However, water is also essential for food production, but are there grounds in international law for stating that there is a right to water for food production or for agriculture more broadly? The FAO Legal Office has been faced with this question in a number of contexts, including in the preparation of a study on water for food security by the High Level Panel of the Committee on World Food Security, and in the elaboration of other international instruments pertaining to water for food and agriculture.

This study is commissioned with a view to bridging existing knowledge gaps on the relationship of the human right to water and effective water governance with sustainable agriculture and the human right to food. This study addresses the above-mentioned question by interpreting the right to water and discussing its linkages with other human rights, in particular, the right to food and other fields of law, from trade and investment law to climate change and biodiversity law, to understand the possible scope of such a human right. It also examines the implications of the human right to water for food production and agriculture for a human rights-based approach to water governance. 



\section{Acknowledgements}

This study was prepared through a Letter of Agreement with the University of Strathclyde, United Kingdom, under the supervision and leadership of Margret Vidar, Legal Officer, FAO and Sisay Yeshanew, International Legal Consultant, FAO. Jessica Marasovic performed editing and layout. 



\section{Acronyms and abbreviations}

$\begin{array}{ll}\text { ACHPR } & \text { African Commission on Human and People's Rights } \\ \text { CBD } & \text { Convention on Biological Diversity } \\ \text { CEDAW } & \begin{array}{l}\text { Convention on Elimination on All Forms of } \\ \text { Discrimination against Women }\end{array} \\ \text { CESCR } & \text { Committee on Economic, Social, and Cultural Rights } \\ \text { CRC } & \text { Convention on the Rights of the Child } \\ \text { EIA } & \text { Environmental impact assessment } \\ \text { FAO } & \text { Food and Agriculture Organization of the United } \\ \text { FSN } & \text { Nations } \\ \text { GATS } & \text { Food security and nutrition } \\ \text { GATT } & \text { General Agreement on Trade in Services } \\ \text { HBRA } & \text { General Agreement on Tariffs and Trade } \\ \text { HLPE } & \text { Human rights-based approach } \\ \text { ICCPR } & \text { High Level Panel of Experts on Food Security and } \\ \text { ICESCR } & \text { Nutrition } \\ \text { IACtHR } & \text { International Covenant on Civil and Political Rights } \\ \text { IIT } & \text { International Covenant for Economic Social and } \\ \text { ILO } & \text { Cultural Rights } \\ \text { IPCC } & \text { Inter-American Court of Human Rights } \\ \text { IWRM } & \text { International Investment Treaties } \\ & \text { intergovernmental Panel on Climate Change } \\ & \end{array}$


LDCs Least-developed countries

OAS Organization of American States

OECD Organization for Economic Co-operation and Development

OHCHR Office of the High Commissioner for Human Rights

RTFG Voluntary Guidelines to Support the Progressive Realization of the Right to Adequate Food in the Context of National Food Security

SDGs United Nations Sustainable Development Goals

UN United Nations

UNCTAD UN Conference on Trade and Development

UNDP UN Development Programme

UNDRIP UN Declaration on the Rights of Indigenous Peoples

UNECE UN Economic Commission for Europe

UNEP UN Environment Programme

UNFCCC UN Framework Convention on Climate Change

UNGA UN General Assembly

UNHRC UN Human Rights Council

UNICEF UN Children's Fund

UNILC UN International Law Commission

UN OHCHR UN Office of the High Commissioner on Human Rights

UNWC UN Watercourses Convention

VGGT Voluntary Guidelines on the Responsible Governance of Tenure of Land, Fisheries and Forests in the Context of National Food Security

WHO World Health Organization

WTO World Trade Organization 


\section{Introduction}

The human right to water is anchored in the human right to an adequate standard of living; a response to concerns that began to attract the international community's attention in the 1970s (Gleick, 1998; Cahill, 2005; and Leb, 2012). The World Health Organization (WHO) estimates that the absolute minimum water required to maintain a person's life is 25 litres per day, but this is unsatisfactory for other needs such as personal hygiene (Hutton and Haller, 2004). Depending on circumstances, water for personal and domestic uses can be satisfied by 50-100 litres per day (Howard and Bartram, 2003). Within the context of the 2030 Agenda for Sustainable Development, adopted by United Nations (UN) Member States on 25 September 2015 (2030 Agenda), the international focus has been on Sustainable Development Goals (SDG) target 6.1 (universal and equitable access to safe and affordable drinking water for all), and target 6.2 (access to adequate and equitable sanitation for all). WHO and the UN Children's Fund (UNICEF) have reported that billions of people have achieved access to the basic services described by these targets since 2000, although faster progress is required to achieve the 2030 targets (WHO and UNICEF, 2017).

The progressive realization of these targets is expected to rely upon the realization of SDG target 6.4:

By 2030, substantially increase water-use efficiency across all sectors and ensure sustainable withdrawals and supply of freshwater to address water scarcity and substantially reduce the number of people suffering from water scarcity (2030 Agenda, 2015).

Water use in the agricultural sector is particularly relevant in this connection. Agriculture uses 70 percent of the global average annual 
freshwater withdrawals, ${ }^{1}$ (which total nearly 4 billion $\mathrm{m}^{2}$ ), ${ }^{2}$ while in least developed states, agriculture accounts for over 90 percent of freshwater withdrawals (FAO, 2011). Renewable freshwater sources total 4.2 billion $\mathrm{m}^{2},{ }^{3}$ but many water sources (such as groundwater) are not renewable in a human timescale (FAO, 2006a; HLPE, 2015). By 2050, global freshwater withdrawals for agriculture may increase to 90 percent (WWAP, 2012), due to population growth, agricultural intensification and changing dietary patterns.

The realization of SDG target 6.4 is complicated by the fact that the planet's water resources are under increasing stress due to population growth, pressure on land from natural resource extraction, energy generation, increasing industrialization and importantly, climate change (WWAP 2012; HLPE, 2015). Anthropogenic climate change will increase uncertainty in the availability, reliability and quality of freshwater resources (Jiménez Cisneros et al., 2014). The Intergovernmental Panel on Climate Change (IPCC) noted that "water is the agent that delivers many of the impacts of climate change to society" (Jiménez Cisneros et al., 2014, p. 234). In particular, climate change may increase uncertainty in water access for agriculture. The IPCC states that due to climate change, "future irrigation demand is projected to exceed local water availability in many places" and rainfed agriculture is vulnerable to increasing change in rainfall (Jiménez Cisneros et al., 2014, pp. 251-2). Further, demand to produce food on either rainfed or irrigated land will rise, due to intensifying weather variability brought about by climate change

World Bank. Development Indicators Annual Freshwater Withdrawals (Agriculture) estimates for 2017 as per available figures. In: World Bank, World Bank Open Data [Online]. [Cited 8 December 2017]. https://data.worldbank.org/indicator/er.h2o.fwag.zs; See also FAO. AQUASTAT. Database. In: FAO [Online]. [Cited 8 December 2017]. http://www.fao.org/nr/ water/aquastat/data/query/index.html

2 World Bank. Development Indicators Annual Freshwater Withdrawals (Total) estimates for 2017 as per available figures. In: World Bank, World Bank Open Data [Online]. [Cited 8 December 2017]. https://data.worldbank.org/indicator/ER.H2O.FWTL.K3?end=2014\&start=1962\&view =chart

3 World Bank. Development Indicators Renewable Freshwater Resources (Total) estimates for 2017 as per available figures. In: World Bank, World Bank Open Data [Online]. [Cited 8 December 2017]. https://data.worldbank.org/indicator/ER.H2O.INTR.K3?end=2014\&start=2014\&view= bar 
(Jiménez Cisneros et al., 2014). According to FAO, focusing on improving the resilience of agricultural systems to reduce current and likely risks from climate variability should be key in adaptation and mitigation strategies (FAO, 2011). As affirmed by Secretary-General Ban Ki-moon on 2012 World Water Day:

[o]ver the coming decades, feeding a growing global population and ensuring food and nutrition security for all will depend on increasing food production. This, in turn, means ensuring the sustainable use of our most critical finite source - water (UN Secretary General, 2012).

The human right to water is thus dependent upon responsible and efficient water use in the agricultural sector. Equally, the human right to water is connected to the realization of the human right to food. The UN World Water Assessment Programme (WWAP) suggests that at least 2000-3000 litres of water per day are required to produce sufficient food (WWAP, 2006). At the household level, there is a disparity in water requirements between households that produce their own food, and homes that do not. But there is still insufficient clarity on the relationship of the human rights to water and effective water governance with sustainable agriculture and the human right to food. Against this background, the present legislative study aims to explore whether the right to water extends to water for food and agriculture. It finds that while the right to water is focused primarily on access to water for drinking, sanitation and other personal and domestic use, it extends to water for food and agricultural production in its interactions with other human rights. This dimension of the right to water has not been developed in as much detail as access to water for drinking and sanitation. Nevertheless, the inter-dependence of the right to water with the right to food is of particular importance for certain groups (rural women and indigenous peoples). This inter-dependence allows this study to clarify the context of the right to water for food and agricultural production. Equally, the study illustrates how the right to water, and other areas of international law, have a bearing on legal frameworks and accountability mechanisms that apply to the usage of water for food and agricultural production. 
The study begins by describing the emergence and content of the international human right to water and other aspects of international human rights law that contribute to clarifying the link between the human rights to water, agriculture and food production. Other areas of international law that contribute to shedding light on this relationship, such as international environmental law, international trade law and international water law, are also explored with a view to providing further insights into the prioritization of water uses in the context of the human right to water. The study concludes by describing what a human rights-based approach, inspired by the preceding analysis, entails for the governance of water resources at the national level, with a view to reflecting a mutually supportive interpretation of the right to water and the right to food that can guide national law-makers. 


\section{The human right to water}

This part of the study provides an overview of the concepts of water rights and water tenure, illustrates the emergence in international law of the human right to water, outlines its normative content, and discusses the obligations arising from it. It finds that, while the right to water is focused primarily on access to water for drinking, sanitation and other personal and domestic use, it extends to water for food and agricultural production in its interactions with other human rights, although this dimension has not been subject to development in significant detail.

\subsection{Water rights and water tenure}

Before embarking upon an analysis of the emergence of the human right to water, it is prudent to first begin with a brief overview of the concepts of water rights and water tenure. A water right is a right to use or access water that is enforceable against other individuals and that can be legally or customarily recognized (FAO, 2006b). An additional concept that has begun to develop in recent years is that of water tenure. In a general sense, tenure determines how people (individually or collectively) gain access to and use natural resources, and how their interests are managed relative to those of others, taking account of rights gained through both formal and customary law (FAO, 2016). The concept has been mainly defined in relation to land. Land tenure has thus been defined as "the relationship, whether legally or customarily defined between people, as individuals or groups, with respect to land" (FAO, 2002b, p. 7). The concept of water tenure may therefore be defined as: "the relationship, whether legally or customarily defined, between people, as individuals or groups, with respect to water resources" (FAO, 2002b, p. xii). Some of the key benefits of this concept are that it promotes bottom-up governance that puts water users at the heart of decision-making, and it allows for the consideration of the nuances of different water uses and tenure systems, rather than fitting a diverse range of scenarios into a limited number of predetermined categories (FAO, 2002b). In this sense, the concept of 
water tenure presents a promising new lens through which to address water governance. Its value is thereby recognized, and further work on the concept is encouraged. However, as the concept is still in its infancy, it is not further addressed here.

Land tenure rights and water rights are central to the realization of human rights such as the right to food and the right to water (Cotula, 2006; Cotula, 2009). ${ }^{4}$ Ownership and limited use rights are often the way in which access to these resources is guaranteed. Equally, land tenure rights and water rights can also hinder the realization of the right to water. An automatic preference in water allocation to formal landowners, for instance, could negatively affect periodic access to water on those lands for subsistence livestock practices by nomadic groups. As property rights in general can be best defined as a social relation between people and a particular object or natural resource (Hann, 1998), land tenure and water rights can only be understood when grounded in a detailed understanding of social institutions that shape the rights to water (Meinzen-Dick and Nkonya, 2007; Meizen-Dick, 2014). This need is also connected to the contextual, transparent and participatory approach to water use prioritization. Human rights, in turn, are relevant for land and water tenure. Property and culture are protected by international human rights law, which also provides for international procedural obligations in relation to transparency and participation (as discussed later in this study).

Ownership rights are not just homogenous rights, but are often conceptualized as bundles of rights that may be held by different parties, and whose allocation may differ depending on further rules of allocation (e.g. seasonal change, environmental conditions, gender). Bundles of rights refer to two distinguished groups of rights: (i) use, access and withdrawal rights and (ii) decision-making rights to regulate and control water use and users (Schlager and Ostrom, 1992). While it is possible

Recent developments, such as the adoption of the 2018 UN Declaration of the Rights of Peasants and Other Persons Working in Rural Areas and the work of the Committee on Economic, Social and Cultural Rights in 2019 on a general comment on the right to land also signal a shift in understanding of the relationship between tenure rights and human rights, towards a stronger recognition of tenure rights as human rights in their own right. 
for a state to claim ownership rights over water, this may not in fact influence local practices of water allocation (Alden Wily et al., 2017). In both civil and common law jurisdictions, law has traditionally conferred use rights, to varying extents, upon the owners of adjacent land in the case of surface water, or super-adjacent land in the case of groundwater (FAO, 2006b). This has historically constrained governments' ability to holistically manage their water resources. In response to several issues raised by such traditional models, recent decades have witnessed a shift towards a more modern system of water governance that generally separates water rights from land ownership.

\subsection{The emergence of a human right to water}

This section provides an overview of key milestones in the development of the right to water in international law. It points out that the emergence of the human right to water in international human rights law has prominently focused on access to safe and clean drinking water and sanitation, although a broader interpretation of the right, which is relevant to food production and agriculture, has been put forward internationally.

The Universal Declaration of Human Rights (UDHR, 1948) and the International Covenant on Economic, Social and Cultural Rights (ICESCR, 1966) do not mention water explicitly. Nevertheless, an international human right to water has progressively emerged from the interpretation of these instruments with respect to the human right to an adequate standard of living. The UDHR provides that:

Everyone has the right to a standard of living adequate for the health and well-being of himself and of his family, including food, clothing, housing and medical care and necessary social services ... (Article 25.1).

Article 11.1 of the ICESCR, which is a widely-ratified treaty (currently 169 State Parties), ${ }^{5}$ declares that:

See OHCHR. Status of Ratifications of the International Covenant on Economic, Social and Cultural Rights. In: OHCHR Indicators [online]. [Cited 5 December 2018]. http://indicators. ohchrorg/ 
The States Parties to the present Covenant recognize the right of everyone to an adequate standard of living for himself and his family, including adequate food, clothing and housing, and to the continuous improvement of living conditions.

What has emerged from these provisions is a primary, but not exclusive, focus on access to safe drinking water.

The 1977 United Nations Water Conference agreed on the non-legallybinding Mar del Plata Action Plan, which features for the first time, access to water expressed in the language of rights:

All peoples, whatever their stage of development and social and economic conditions, have the right to have access to drinking water in quantities and of a quality equal to their basic needs. (Resolution II, Community water supply, para. (a)).

In addition, the Conference led to the International Water Supply and Sanitation Decade (1980-1990) and laid the foundations for further development of the concept of integrated water resources management (IWRM) as the main driver of water governance in the years to come (see Section 4.2).

The 1990s saw a blossoming of international legal instruments related to the environment and water law. In 1992, the International Conference on Water and the Environment adopted the non-binding Dublin Statement on Water and Sustainable Development (Dublin Statement, 1992). The Dublin Statement lays down four guiding principles, including a reference to a right to water:

Water has an economic value in all its competing uses and should be recognized as an economic good. Within this principle, it is vital to recognize first the basic right of all human beings to have access to clean water and sanitation at an affordable price. Past failure to recognize the economic value of water has led to wasteful and environmentally damaging uses of the resource. Managing water as an economic good is an important way of achieving efficient and equitable use, and of encouraging conservation and protection of water resources (Principle 4, emphasis added). 
Although the Dublin Statement placed significant emphasis on the economic value of water, this narrow perspective of water as an economic good changed quickly in international law and policy. Also in 1992, Agenda 21, a soft-law blueprint adopted at the Rio Conference on Environment and Development, recognizes that: "Fresh water is a finite and vulnerable resource, essential to sustain life, development and the environment" (Agenda 21, 1992, Principle 1). Agenda 21 includes a specific chapter dedicated to the "Protection of the Quality and Supply of Freshwater Resources," recognizing "water as an integral part of the ecosystem, a natural resource and a social and economic good" and thus, already broadening the economic perspective of the Dublin Statement. The same Chapter of Agenda 21 elaborates on the integration of land and water activities within the management and use of water resources, underscoring the need to cooperate and establish mechanisms to solve transboundary issues. It recommends an ecosystem approach (see Section 3.4), referring to the unitary nature of freshwater bodies and the interconnectedness of the elements related to freshwater quality. Additionally, a reference is made to the importance of considering human basic needs, and the need to safeguard the ecosystem when prioritizing uses (UNCED, 1992). The Mar del Plata Action Plan, Convention on Elimination on All Forms of Discrimination against Women (CEDAW), Convention on the Rights of the Child (CRC), the Dublin Statement, and Agenda 21 all linked an adequate standard of living and basic needs to water.

In 2003, the Committee on Economic, Social and Cultural Rights (CESCR) adopted General Comment No. 15: The Right to Water (GC 15, CESCR, 2002a), clearly enshrining access to water as a human right, and moving away from considering water mainly as an economic good: "Water should be treated as a social and cultural good, and not primarily as an economic good" (para. 11). It also clarified that the human right to water is not static, but should focus on sustainability: implementation should not only meet the needs of present, but also of future generations (para. 11). It further underscored its link, in light of its multiple and fundamental purposes (para. 6), with other human rights - not only the right to an adequate standard of living, but also the right 
to health (ICESCR, 1966, Articles 11 and 12 respectively) and "foremost among [these rights] the right to life and human dignity" (para. 3).

With regard to the link to the right to life, General Comment No. 15 clarifies that:

The right to water clearly falls within the category of guarantees essential for securing an adequate standard of living, particularly since it is one of the most fundamental conditions for survival (para. 3).

The basic necessity of water for the sustenance of human life has been reaffirmed, for example, by UN General Assembly (UNGA) (UNGA Res/64/292, 2010, para. 1). The International Covenant on Civil and Political Rights (ICCPR), which protects the right to life (ICCPR, 1966, Article 6), entails a general obligation on State Parties (of which there are 172) to respect and ensure the rights to all persons subject to their jurisdiction, also "without distinction of any kind, such as race, colour, sex, language, religion, political or other opinion, national or social origin, property, birth or other status" (ICCPR, 1996, Article 2). This includes a negative obligation to refrain from interference with the enjoyment of the right to life, and a positive obligation to take "legislative, judicial, administrative, educative and other appropriate measures" to ensure the enjoyment of the right, including protection from the acts of third parties (General Comment No. 31, HRC, 2004, paras. 3, 6, 7, 8 and 10).

General Comment No. 15 of the CESCR also understands the right to water as implicit in, and so fundamentally connected to, the right to the highest attainable standard of health (GC 15, CESCR, 2002a). This builds on CESCR's earlier General Comment No. 14 (GC 14, CESCR, 2000) on the right to the highest attainable standard of health, which indicated that a central aspect of the normative content of the right to health derives from a focus on the underlying determinants of health "such as ... access to safe and potable water and adequate sanitation" (para. 4). The same General Comment also included among the determinants of health "food and nutrition" and "a healthy environment" (para. 4), which are also connected to the human right to water as discussed below. 
Successive international developments have, however, focused on a narrower concept of the right to water in terms of access to safe and clean drinking water and sanitation, even if the broader relevance of the human right to $\mathrm{r}$ other human rights was acknowledged. The UN Human Rights Council (HRC) clarified in 2007, that access to safe drinking water and sanitation had to be framed as a human rights issue (HRC, 2007). In 2008, the HRC defined the mandate of an independent expert (UN Special Rapporteur) on human rights obligations related to access to safe drinking water and sanitation with the task to promote and develop a dialogue between states, UN bodies, the private sector, local authorities and civil society organizations (HRC Res/7/22, 2008). In 2010, the UNGA addressed the right to water in its influential Resolution 64/292, ${ }^{6}$ which "Declares the right to safe and clean drinking water and sanitation as a human right that is essential for the full enjoyment of life and all human rights" (para. 1). In the same year, the HRC adopted by consensus Resolution 15/9, calling upon states to progressively achieve the full realization of human rights obligations related to access to safe drinking water and sanitation (HRC Res/15/9, 2010). ${ }^{7}$ And while the SDGs do not include any direct reference to a human right to water, the wording of SDG 6 (availability and sustainable management of water and sanitation) and of its Target 6.1 (universal and equitable access to safe and affordable drinking water for all), is clearly informed by these international developments regarding the human right to water, focused on access to safe and clean drinking water and sanitation (UNGA Res/70/169, 2016, para. 3).

\subsection{General Comment No. 15 on the normative content of the right to water}

While the emergence of the right to water in international human rights law shows a prominent focus on access to safe and clean drinking water and sanitation, General Comment No. 15 offers a broader interpretation

Although, the Resolution was not adopted by consensus: 122 votes in favour, none against and 41 abstentions. See also The human rights to safe drinking water and sanitation. UNGA, A/RES/70/169, 2015.

$7 \quad$ Adopted without a vote. 
of the right. This matters, as General Comment No. 15 remains the most detailed elaboration of the normative content of the right to water and is widely regarded as authoritative (Craven, 1995; Cahill, 2005; and FAO ed., 2009). Notably, General Comment No. 15 refers to water for "personal and domestic uses" including "food preparation" (GC 15, CESCR, 2002a, para. 12(a)). It further recognizes that water is required for varying uses beyond the personal and domestic (para. 6), explicitly noting that food production through agriculture is one purpose of water use, beyond personal and domestic use, which depends upon sustainable access to water and which is essential for realizing the right to food (para. 7).

This section will thus rely on General Comment No. 15 to discuss the normative content of the right to water in a broad perspective. It outlines the degree to which the right to water can be seen to extend to water for food and agriculture based on the understanding of what securing the right to water for non-personal and domestic uses might entail.

General Comment No. 15 specifies that the human right to water encompasses both "freedoms and entitlements" (GC 15, CESCR, 2002a, para. 10). These include freedom from interference, to keep water services that provide access to clean water, not to be disconnected from the water services that one is using, and entitlement "to sufficient, safe, acceptable, physically accessible and affordable water for personal and domestic uses" (para. 2). Entitlements also include "the right to a system of water supply and management that provides equality of opportunity for people to enjoy the right to water" (para. 10).

General Comment No. 15 articulates the following factors that are required to secure the right to water: water availability, quality, and accessibility (GC 15, CESCR, 2002a, para. 12). In terms of availability, water supply for each person must be sufficient and continuous (i.e. "the regularity of the water supply is sufficient") for personal and domestic uses, including food preparation (GC 15, CESCR, 2002a, para. 12(a)). Quantity of water is to be determined by reference to WHO guidelines (rather than a prescribed volume, as WHO guidelines may change over time) and some 
individuals and groups may also require different amounts of water due to health, climate, and work conditions.

In terms of quality, water for personal and domestic use must be safe and free from contaminants (micro-organisms, chemicals, etc.) that threaten a person's health. Water should be of an acceptable colour, odour, and taste for personal or domestic use.

In terms of accessibility, water and water facilities and services must be accessible to everyone without discrimination, within the jurisdiction of the State Party. This principle has four overlapping dimensions:

- Physical Accessibility: access must be within physical reach of all and physical security should not be threatened during access to water facilities and services.

- Economic Accessibility: water and water facilities and services must be affordable for all ("The direct and indirect costs and charges associated with securing water must be affordable, and must not compromise or threaten the realization of other covenant rights") (GC 15, CESCR, 2002a, para. 12(c)(ii)).

- Non-discrimination: water and water facilities and services must be accessible to all, including the most vulnerable or marginalized sections of the population.

- Information Accessibility: accessibility is also understood as the right to seek, receive and impart information about water issues.

In summary, General Comment No. 15 focuses on the normative content of the right to water as it relates to water for personal and domestic use, while also recognizing that the right extends to other uses where required to realize related rights. From a substantive perspective, General Comment No. 15 states that for the human right to water to be realized, water for personal and domestic use must be safe and available to all in sufficient quantities. On the other hand, General Comment No. 15 does not explicitly link accessibility of water to personal and domestic use, so the overlapping dimensions of accessibility can also be considered relevant for water for food production and agriculture. As will be 
discussed in the next chapters, water availability, quality, and accessibility are also relevant from the perspective of other areas of international law (environmental and economic, for instance: Chapter 3) and of other inter-linked human rights (notably the right to food: Chapter 2).

\subsection{International obligations arising from the right to water}

Before discussing the interface of the right to water and the right to food in more depth, this section aims to situate the obligations arising from the right to water. The normative content of the right to water must be considered within the context of general and specific obligations that fall upon State Parties to the ICESCR. These obligations include an obligation not to discriminate, an obligation to take progressive steps to realize the right to water (general obligations), as well as obligations to respect, protect and fulfil the right (specific obligations). Obligations of international cooperation apply in respect of the right to water, as they do in respect of other human rights. Furthermore, business entities are also expected to respect the right to water.

\subsection{General obligations}

General Comment No. 15 clarifies the general obligations that apply to the right to water, notably non-discrimination and progressive realization. These obligations mirror those applicable to all rights enshrined in the ICESCR. State Parties should "guarantee that the right [to water] will be exercised without discrimination of any kind" (ICESCR, 1966, Article 2.2). ICESCR Article 2.1 provides for the obligation of progressive realization:

Each State Party to the present Covenant undertakes to take steps, individually and through international assistance and cooperation, especially economic and technical, to the maximum of its available resources, with a view to achieving progressively the full realization of the rights recognized in the present Covenant by all appropriate means, including particularly the adoption of legislative measures.

State Parties have an obligation to take steps towards the full realization of the right to an adequate standard of living and to health (GC 15, CESCR, 2002a, para.17). They have a due diligence obligation to move towards the 
progressive realization of the human right to water. Because State Parties, at least in principle, have the power to take measures in the field of access to water, they have an obligation to move forwards, and, logically, not backwards. Thus, General Comment No. 15 clarifies that "retrogressive measures taken in relation to the right to water are prohibited under the Covenant" (para. 19). As noted by Special Rapporteur Catarina de Albuquerque, it is important to stress this prohibition, especially in times of crisis and budget cuts (HRC, 2013b).

State Parties' duties to secure a minimum core of the right to water are of immediate effect (GC 15, CESCR, 2002a, para. 37). General Comment No. 15 identifies a number of such obligations, including to:

- "ensure physical access to water facilities or services" (para. 37(c));

- "ensure equitable distribution of all available water facilities and services" (para. 37(e)); and

- "adopt relatively low-cost targeted water programmes to protect vulnerable and marginalized groups" (para. 37(h)).

While the identification of minimum core obligations could be relevant in the context of prioritization of water use, the absence of clear methodology in the identification of such obligations and the lack of consistency in the general comments of the CESCR with regard to the derogability of the minimum core, makes it a sub-optimal standard to use. Legal commentators have, for example, concluded that while water for food production and agriculture are elements of the right to water, it is only when its use is essential for survival that it is at the core of the right to water (Cahill, 2005; Winkler, 2017). This would as well be misleading in its failure to take contextual differences into account. It is recognized, for example, that the right to water within agrarian societies may require a different consideration than water for communities that draw their livelihood from other vocations. That said, these obligations have not been interpreted consistently by the CESCR with regard to the availability of resources. Without entering into the merits of this discussion, this points to the need to consider water for food production 
and agriculture as part of a prioritization of water uses that also takes into account the relevance of the right to water for the realization of other human rights (see Chapter 2).

\subsubsection{Specific obligations}

The human right to water entails specific obligations, which mirror those applying to other ICESCR rights - the obligation to respect, to protect and to fulfil. In the context of the right to water, these obligations can be understood as:

- Respect: States are required to refrain from interfering directly or indirectly with the enjoyment of the right to water.

- Protect: States are required to prevent third parties from interfering with the right to water. Legislation must restrain third parties from restricting or denying equal access to water. When water services are operated by third parties, States must prevent regulatory abuse by said parties, which would compromise equal, affordable, and physical access to safe and acceptable water.

- Fulfil: This includes the duties to facilitate, promote, and provide. States are required to adopt appropriate legislative, administrative, budgetary, judicial, promotional and other measures to fully realize the right to water. These are positive obligations to assist individuals and communities to enjoy the right to water. As indicated above, sustainability is a key concern here: General Comment No. 15 thus recommends that State Parties should "adopt comprehensive and integrated strategies and programmes to ensure that there is sufficient and safe water for present and future generations" (GC 15, CESCR, 2002a, para. 28).

\subsubsection{Procedural obligations}

The human right to water has procedural dimensions that are crucial for the realization of its substantive dimensions. Special Rapporteur Catarina de Albuquerque has pointed to "the core human rights principles of 
participation and empowerment, accountability, non-discrimination and equality, transparency and access to information" (HRC, 2013b, para. 15). Some of these considerations are already captured under the notion of accessibility, and more generally relate to a human rights-based approach to water for food production and agriculture (see Chapter 4).

Procedural rights are expected to "enable resource users to have a greater say in decisions affecting their access to resources" (FAO, 2008, p. 14). More specifically, the right to information facilitates public access to information about: water-related issues and human health, proposed water projects, law and policies affecting or potentially impacting water resources and threats to the environment and possible response measures (Scanlon, Cassar and Nemes, 2004). Information enables rights holders to participate meaningfully in decisions that directly affect their livelihoods and therefore, promotes accountability and transparency in decision-making of the competent authorities in the water sector (Scanlon, Cassar and Nemes, 2004). Effective public participation in decision-making concerning water issues requires "education, access to information, a role in decision-making, transparency of decisionmaking processes, monitoring, environmental impact assessment and enforcement mechanisms" (Popovic, 1996, p. 555), with the understanding that superficial consultation or information sharing is not true public participation, as it does not empower civil society to influence decisions (HRC, 2011).

Another key procedural dimension is that states (and their courts) must recognize that the right to water is a justiciable human right (Scanlon et al., 2004; Olmos Giupponi and Paz, 2015) and that all rights holders have the right to a remedy, which ensures the legal protection of human rights (FAO, 200ab), and is a well-established human right in itself. The right to a remedy guarantees that victims of human rights violations can undertake and rely on meaningful enforcement measures; it also obliges states to establish new mechanisms to provide effective remedy where existing mechanisms are inadequate (UNGA Res/60/147, 2006; Boyle, 2012). 


\subsubsection{International cooperation}

Progressive realization includes an obligation of international assistance and cooperation. International cooperation is an aspect of the obligation to fulfil (to facilitate, promote, and provide). States Parties to the ICESCR must cooperate, resources permitting, to support the full realization of the right to water in other States (GC 15, CESCR, 2002a, para. 34). State Parties have an obligation to recognize that international cooperation is necessary to achieve the full realization of the Covenant rights (ICESCR, 1966, Articles 2.1, 11.1 and 23; GC 15, CESCR, 2002a, paras. 30-31). The conclusion and implementation of new international agreements should not adversely impact on the right to water (para. 35) and there is a heightened requirement to assist developing states to meet minimum core obligations (para. 38). Thus, these obligations also concern other areas of international law that may affect the right to water, such as international economic law and international environmental law (see Chapter 2). Article 23 of the ICESCR gives examples of practical measures of assistance and practices of cooperation:

The State Parties to the present Covenant agree that international action for the achievement of the rights recognized in the present Covenant includes such methods as the conclusion of conventions, the adoption of recommendations, the furnishing of technical assistance and the holding of regional meetings and technical meetings for the purpose of consultation and study organized in conjunction with the Governments concerned.

The obligation of international assistance and cooperation indicates that obligations to respect, protect and fulfil may have an extraterritorial reach (e.g. Report of the Independent Expert on human rights and the environment, John H. Knox, HRC, 2013a, para. 63). Violations of ICESCR rights in an extraterritorial context might derive from the activities of States Parties, from a failure of States Parties to protect against the acts of private entities, or from a failure of States Parties to take measures in pursuit of the fulfilment of the rights. However, the nature and consequences of extraterritorial obligations are still developing. In 2017, the CESCR adopted General Comment No. 24 (GC 24, CESCR, 2017) relating specifically to states' obligations to regulate and control the 
impacts of business activities (within and outside of the States Parties' territories) across all the ICESCR rights.

There has been recent discussion among experts about the extent to which responsibility for interferences and lack of action can or should be attributable to ICESCR States Parties, not only in respect of the actions of business activities, but more broadly (Salomon and Seiderman 2012; De Schutter et al., 2012; ETO Consortium, 2011; HRC, 2013c). The CESCR has acknowledged extraterritorial obligations, specifically in relation to the right to water, noting that States Parties' own activities may interfere directly or indirectly with the enjoyment of the right to water in other states, and that parties must avoid such interference (including through the imposition of economic sanctions) (GC 15, CESCR, 2002a, para 31), States Parties must also take steps to protect the enjoyment of the right to water in other states (para. 33), by taking steps to prevent their own citizens or companies from breaching obligations attached to the right to water when operating in other states (GC 24, CESCR, 2017, paras. 25-37).

Therefore, across national boundaries, and within international fora, ICESCR States Parties should contribute to processes aimed at the full realization of the right to water. Furthermore, the obligation of international cooperation does not derive solely from the ICESCR. The commitment to international cooperation in pursuit of human rights protection by all states is also enshrined in the Charter of the United Nations (Articles 55 and 56). International cooperation also reflects the principle of interconnectedness of all human rights, the realization of which also depends on the relationships between various states, including in other policy areas (such as trade and investment, as discussed in Chapter 3).

\subsubsection{Responsibility of non-state actors}

States remain the primary duty bearers under international law, including in terms of regulating and controlling private actors' conduct. But calls have been made for the full participation of non-state actors too. The UN Guiding Principles on Business and Human Rights set authoritative standards on the responsibility of 
business entities to prevent, mitigate and remedy adverse impacts on internationally recognized human rights, over and above what is required of them by national laws, and independently of states' abilities and willingness to fulfil their human rights obligations (HRC Res/17/4, 2011, Principles 11-24). The UNGA, in 2016, called "upon non-state actors, including business enterprises, both transnational and others," to comply with their responsibility to respect human rights, including the human rights to safe drinking water by, for example, cooperating with state investigations into allegations of abuses of this right and by progressively engaging with states to detect and remedy abuses of this right (UNGA Res/64/292, para. 2). The UN Special Rapporteur on Human Rights and the Environment, John Knox, also underscored that businesses should respect the right to water, including by complying with the Guiding Principles on Business and Human Rights in all actions that may affect biodiversity (see Section 3.4). He recommended that business follow international guidelines on socio-cultural and environmental assessments when proposed developments may affect water resources traditionally owned or occupied by indigenous peoples and local communities (HRC, 2017; see Section 3.4.2).

Other relevant non-state actors are international organizations in the field of development cooperation. UN Special Rapporteur on the right to water, Leo Heller, suggested a practical and action-oriented "human rights development cycle" with which to tackle the current "patchwork" approach to the human right to water in development cooperation (UNGA, 2017). This is particularly important considering that a significant amount of the work that will be undertaken to implement SDG 6 by 2030 will be in the form of assistance to states by international organizations and non-governmental organizations (NGOs) through donor funding, especially in those parts of the world that still lack basic access to water services. Heller recommended, inter alia, "refrain[ing] from imposing conditionalities in the provision of loans and grants" and making donor organizations and international organizations truly accountable when their actions breach their responsibility to promote the human right to water (UNGA, 2016, para. 74(e)). For this to happen, states should be mindful that they remain bound by international human 
rights obligations, also in the context of their decision-making role within international organizations. The CESCR made such an observation with regard to the right to social security (General Comment No. 19, CESCR, 2007, para. 58), indicating that states should ensure that their actions as members of international organizations take due account of the right in lending policies, credit agreements and other international measures, and ensure that the policies and practices of international and regional organizations promote and do not interfere with the right.

\subsection{Preliminary conclusions}

The right to water has developed as a self-standing right, which is inextricably connected to the right to an adequate standard of living and is understood to be inherent also in the right to health and the right to life. It entails general and specific obligations, as well as procedural obligations and an obligation of international assistance and cooperation. It also sets expectations about the conduct of private companies and international organizations.

General Comment No. 15 on the right to water, which is the most detailed authoritative elaboration of the normative content of the right to water, identified four connections between the right to water and food.

- First, the human right to water extends to water for food preparation: water is essential to preparing food for human consumption. General Comment No. 15 notes that an adequate quantity of water is necessary to provide for cooking (para. 2). This falls within personal and domestic use.

- Second, General Comment No. 15 states that priority should be given to water resources required to prevent starvation (para. 6). This can be related to an earlier interpretation suggested by the OHCHR that the right to water ensures priority for water use in agriculture and pastoralism when necessary to prevent starvation (OHCHR, 2002).

- Third, General Comment No. 15 indicates that food production through agriculture is one purpose of water use, beyond personal 
and domestic use, which depends upon sustainable access to water. General Comment No. 15 indicates that water for agriculture is intertwined with the right to food. This is consistent with, and a reflection of, the interdependence of rights within and beyond ICESCR.

- Fourth, the General Comment also observed that access to water is essential for securing livelihoods (right to gain a living by work) and enjoying certain cultural practices (right to take part in cultural life) (para. 6) that could both be linked to certain (subsistence and/or traditional) agricultural practices. Accordingly, it called attention to the obligations of States Parties to the ICESCR to ensure "equitable access to water and water management systems, including sustainable rain harvesting and irrigation technology" for disadvantaged and marginalized farmers, and "adequate access to water for subsistence farming and for securing the livelihoods of indigenous peoples" (para. 7). CESCR's General Comment No. 15 therefore makes particular reference to farmers in relation to the realization of the right to food.

Legal commentators have, however, underscored that the linkage between the right to water and food was treated "as an add-on to a document focused on water for personal and domestic uses" (Winkler, 2017, p. 87). In effect, no consensus could be reached on including in General Comment No. 15 a statement that:

[t]he right to adequate food entitles an individual or group to secure the water necessary for the production of food to ensure, at least, freedom from hunger where there is no alternative to securing essential foodstuffs for the population concerned (CESCR, 2002b, para. 6).

As a result, the content of the right to water has been clarified primarily in terms of access to safe drinking water and sanitation, and water for personal and domestic use.

In addition, legal commentators have considered that the focus on water for personal and domestic uses is biased towards urban areas (Winkler, 
2007; Langford 2009), whereas in rural areas, more people are dependent on producing their own food and consequently dependent on access to water for that end, so that prioritization of allocation of water should be given to them (Winkler, 2007; Langford 2009). This aligns with an FAO submission stating that:

[t]he role of water for traditional livelihoods and the specific situation of pastoralists and people in societies where livestock is of over-arching importance should be considered as a separate issue. In these contexts, a sharp differentiation and prioritization of water for human consumption and of water for food production does not reflect the peculiarities of pastoral systems (FAO, 2002a, p. 3).

The extent to which the right to water extends to food production and agriculture will be clarified in the next chapter by further exploring the interface between the right to water and other human rights, notably the right to food as well as the human rights of indigenous peoples and rural women. 



\section{The human right to water for food and agriculture}

This chapter considers the interface of the right to water with other human rights. This is because the right to water must be realized in a manner consistent with other relevant human rights obligations. This chapter will first discuss the relationship between the human right to water and the human right to food, and some of the challenges that arise from it. It then considers the relevance of the human rights of particular groups, such as women (rural women, especially) and indigenous peoples, as these norms clarify the content of the right to water in as far as it extends to food production and agriculture.

\subsection{Insights and challenges from the perspective of the right to food}

Food is explicitly mentioned as a condition necessary for realizing the right to an adequate standard of living, as part of a non-exhaustive list in the UDHR (Article 25) and the ICESCR (Article 11). Like the right to water, the right to food derives from the right to an adequate standard of living. In addition, food is recognized, again like water, as implicit in realizing the right to health, even if the right to the highest attainable standard of health is silent on food (ICESCR, 1966, Article 12). Thus, it can be observed that the normative content of the right to water has developed in a similar way to the right to food, which supports the view that the normative content of the two rights is intimately connected and these rights are therefore expected to mutually support the realization of one another with a view to contributing to an adequate standard of living.

General Comment No. 12 of the CESCR on the right to food is silent on water but makes broad references to "resources" (GC 12, CESCR, 1999, paras. $12,15,17,21,25$ and 26), so drinking water is seen as part of food, 
as reflected in the mandate of the UN Special Rapporteur on the right to food (HRC Res/31/10, 2016).

On these bases, the relationship of the right to food and the right to water has been the object of reflection by the UN Special Rapporteur on the right to food. In his first report in 2001, Special Rapporteur Jean Ziegler made reference to the agricultural aspects of access to irrigation water, "which is clearly linked to the viability of food production and the capacity of people to feed themselves" (UNGA, 2001). He noted that:

[E]veryone must have access to drinking water on equal terms and that irrigation water should also be accessible for poor peasants who depend on their land to feed themselves. As a component of the right to food, access to safe, clean drinking water and basic irrigation water must be protected under the obligations to respect, protect and fulfil the right to food and through international cooperation (UNGA, 2001, para. 71).

In addition, Ziegler recognized water as an essential feature of nourishment and stated that nutrition and water are key elements that constitute the right to food:

[G]iven its close link with the definition of food security, the right to food should not only include availability and access as key elements of the definition but also the utilization of food as a third key element ... which requires a diet adequate in energy and nutrient, as well as safe drinking water and adequate sanitation.

[I]t is impossible to discuss nutrition and food security without including safe drinking water. Safe drinking water is essential to adequate nutrition. Another element of the right to food must be water used for irrigation purposes, given that this is essential for food production and for ensuring food availability, particularly in countries where the poor depend primarily on their own production (HRC, 2003, paras. 34-5).

The Voluntary Guidelines to support the Progressive Realization of the Right to Adequate Food in the Context of National Food Security are also relevant here. The Right to Food Guidelines (RTFG) were adopted in 2004 by the FAO Council to clarify the content of the right to food and guide its implementation, and to recognize that access to natural 
resources such as water represents a precondition for the full realization of the right to adequate food. The Guidelines clarify state obligations to respect and protect the rights of individuals regarding access to natural resources such as water, and facilitate sustainable, non-discriminatory, gender-sensitive and secure access to such resources, if necessary, by undertaking land reform. With regards to water, states are expected to improve access to water resources and promote its sustainable use and allocation. The equitable distribution of water must satisfy basic human needs and reconcile the preservation of ecosystems with domestic, industrial and agricultural needs, including safeguarding drinking-water quality" (para. 8.11).

While from the perspective of the right to food, there has been recognition that water for personal consumption and for irrigation or agricultural production is essential for the realization of the right to food, different terminologies and distinctions are used in relation to various possible connections between the right to water and the right to food. For instance, while on the side of the right to water, distinctions are made between water uses, e.g. between individual, household, and agricultural uses, the Right to Food Guidelines discuss water for "domestic, industrial, and agricultural needs" (RTFG, 2004, para. 8(c)). Besides the lack of coherence, these distinctions may also be misleading: rural and periurban areas require water for not only personal and domestic uses "but also for other uses relating to the broader goals of poverty reduction and livelihood security" (Winkler, 2017, p. 84). Communities in rural and peri-urban areas are exercising their right to water for a multitude of purposes beyond traditional domestic uses (drinking and sanitation), such as for productive uses that include, but are not limited to, growing food and raising livestock (Hall, Van Koppen and Van Houweling, 2014). In doing so, a household or community raises its income and boosts food and livelihood security (Hall, Van Koppen and Van Houweling, 2014). Should small-scale subsistence agriculture fall under the umbrella of "domestic" or "agricultural" water use? Subsistence agriculture could be seen as part of individual or household water use, thus falling within definitions of "water for personal and domestic uses ambit". On the other hand, OHCHR has argued that this comes within the right to food, not 
the right to water $(\mathrm{OHCHR}, 2002$, p. 12). Further, such distinctions are artificial in the context of indigenous peoples and pastoralists: livestock may be of overarching importance for the livelihoods of such communities and as such, the division of water prioritisation between water for food production and water for human consumption is not representative of the characteristics of pastoral or indigenous communities.

Another issue inadequately addressed by these distinctions is that many agricultural activities do not produce food ("non-foods"), and that there is more than one pathway to realize the right to food through agriculture. "Cash-crops" (i.e. non-foods, such as cotton, cut flowers, bio-fuels, as well as water-heavy foods produced in the Global South but exported to the Global North such as strawberries, grapes and citrus fruit) can provide the income for communities to enhance their access to more nutritious food on the market than what could be available to them through subsistence food agriculture. General Comment No. 12 (GC 12, CESCR, 1999) on the right to food notes that availability of food includes both:

feeding oneself directly from productive land or for well-functioning distribution, processing and market systems that can move food from the site of production to where it is needed in accordance with demand (para. 12).

Further, General Comment No. 12 clarifies that accessibility of food encompasses both economic and physical access (para. 13). The interface between water, agriculture and economic subsistence, is granted recognition in the United Nations Declaration on the Rights of Peasants and Other People Working in Rural Areas which was adopted by the UNGA in December 2018. The Declaration, which seeks to empower peasants and rural communities, with particular attention to women and youths, ascribes to them the "right to water for personal and domestic use, farming, fishing and livestock keeping and to securing other waterrelated livelihoods" (UNGA RES/73/165, 2018, Article 21.2). 


\subsubsection{Insights from the High Level Panel of Experts on water for food security and nutrition}

In 2015, the High Level Panel of Experts (HLPE), the science-policy interface of the Committee on World Food Security (CFS), produced a report titled "Water for food security and nutrition " (HLPE, 2015) as part of its independent and evidence-based analysis and advice to inform policy making. The report highlighted the essential nature of water of sufficient quality and quantity for agriculture production and food processing and preparation (HLPE, 2015). The HLPE also noted that while some national water policies prioritize water allocation for food security and nutrition, many do not. Implementing such prioritization was highlighted as a challenge due to lack of integration in decisionmaking, and decisions in different water use sectors taken by separate departments with "little consideration for the cumulative impacts of water." The HLPE advocated for the production of "practical guidelines that outline the implications of the right to food in relation to the right to water, and vice versa" (HLPE, 2015, para. 39). The report concluded that climate change will alter the availability of water in rainfed and irrigated agriculture systems. This stressor will be combined with increasing competition from other water sectors (energy, industry, population growth). For irrigated agriculture in particular, management of water will be essential in climate change adaptation. The HLPE Report proposed methods for actors concerned with water and for food security and nutrition to "improve water management for agriculture; to improve management of agricultural and food systems for water, and to improve water governance for food security and nutrition" (HLPE, 2015, p. 1078). The HLPE also underscored that trade can facilitate the compensation for water scarcities between regions (HLPE, 2015; see Section 2.2). HLPE proposed three principles at all levels (integration, prioritization and inclusiveness), indicating that water governance should have the right to water and the right to food as driving principles (HLPE, 2015), and underscoring the need for improving water access to vulnerable populations and women, and for ensuring participation of local communities in sustainable and integrated land and water management. 
In 2015, CFS inter-governmentally negotiated and agreed by consensus, a series of recommendations based on the HLPE report. The CFS recommendations address issues related to promoting implementation of all water-related human rights obligations and achieving access to water for all (Policy Recommendation, 2015). The recommendations address in particular:

- improving coherence between water and food security and nutrition-related policies, strategies and plans;

- achieving equal access to water for all, prioritizing the most vulnerable and marginalized at all ages and empowering women and youth, including implementing policies for equal opportunities and security in access to water and land for food producers, respecting the rights and addressing the needs of specific groups including the most vulnerable;

- improving the efficiency and diversity of water use and the productivity of agricultural systems for food security and nutrition, including strengthening capacities to adopt watersaving practices and technologies for water storage and reuse;

- Managing risk and increasing resilience to water variability for food security and nutrition, including preventing and minimizing significant food price volatility risks;

- respecting traditional knowledge on sustainable water management (see Section 3.4.2);

- developing and sharing knowledge, technologies and tools related to water for food security and nutrition, including supporting cross-sectoral and multi-stakeholder participatory and independent platforms; and

- promoting the full and meaningful implementation of international human rights obligations and instruments as they relate to water for food security and nutrition, including acknowledging the linkages between the right to water and the progressive realization of the right to food, and assessing the 
effects of water and land-related policies, such as large-scale land acquisitions, on the progressive realization of these rights.

In addition, the 2015 recommendations of the CFS address sustainable ecosystem management as a structural precondition for the realization of the right to water, calling for:

- promoting sustainable management and conservation of ecosystems for the continued availability, quality and reliability of water for food security and nutrition, including an ecosystem approach (see Section 3.4) and collection of water-related information in all sectors; and

- fostering inclusive and effective collaboration and national and local governance on water for food security and nutrition, including promoting collaborative water management and best practices for the sustainable use of transboundary water basins.

One notable omission from the CFS recommendations, when compared with the HLPE Report, was any mention of improving the contribution of trade to water for food security and nutrition (see Section 3.2).

\subsection{Groups requiring special consideration}

When implementing human rights, including the right to water and its connections with the right to food and traditional or subsistence agriculture, special consideration should be given to the rights of specific groups, including vulnerable and marginalized groups. Key considerations are the protection of the rights without discrimination, and procedural rights to participation. Special considerations for women and indigenous peoples have in fact, been a vehicle for clarifying a connection between the right to water, food and agriculture. It is through these special considerations, combined with a contextual reading of the right to water and the right to food in particular, that the scope of the right to water for food and agriculture can be further clarified. 


\subsubsection{Women}

The 1979 CEDAW obliges State Parties to ensure rural women the right "to enjoy adequate living conditions, particularly in relation to housing, sanitation, electricity and water supply, transport and communications" (CEDAW, 1979, Article 14.2(h)). The CEDAW therefore considers access to water, including clean drinking water, instrumental for complying with the right to an adequate standard of living and the right to health for women. It is noted that this would be restricted to domestic uses rather than agriculture.

CESCR's General Comment No. 15 also makes particular reference to women farmers, linked to the realization of the right to food: States Parties must ensure "equitable access to water and water management systems, including sustainable rain harvesting and irrigation technology" for "disadvantaged and marginalized farmers, including women farmers" (para. 7). More broadly, General Comment No. 15 clarifies that, "[w]hereas the right to water applies to everyone, States Parties should give special attention to those individuals and groups who have traditionally faced difficulties in exercising this right, including women" (para. 16; emphasis added). Regional human rights regimes contain examples of special provisions for women, which link water use to food production by different means. For example, within the African regional human rights system, the 2003 Protocol to the African Charter on Human and Peoples' Rights on the Rights of Women in Africa includes access to clean drinking water and the "means of producing nutritious food" (Article 15(a)) in order to secure a right to food security.

Furthermore, CESCR has underscored the importance of the procedural dimension of the right to water for women in particular, through the obligation of States Parties to take steps to ensure that "[w]omen are not excluded from decision-making processes concerning water resources and entitlements" (GC 15, CESCR, 2002a, para. 16(a)). Along similar lines, in 2016, the UNGA urged states to step up efforts to progressively realize the right to water through, inter alia, women's participation in decisionmaking on water management and gender based-approaches in waterrelated management practices (UNGA Res/70/169, 2016, para. 5(e)). 
Overall, these provisions underscore how the linkages between the right to water and women's rights require, within the scope of the right to water, special attention (substantive and procedural) for women's right to food.

\subsubsection{Indigenous peoples}

Access to water has special importance for indigenous peoples. The 1989 International Labour Organization (ILO) Indigenous and Tribal People's Convention, No. 169, does not explicitly provide for a right to water, but provides that the rights of indigenous and tribal peoples "to the natural resources pertaining to their lands shall be specially safeguarded." In that context, "natural resources" include water (ILO, No. 169, 1989, Article 15.1; ILO, 2009, p. 107) and the term "lands" includes "the total environment of the areas which the peoples concerned occupy or otherwise use" (Article 13.2). In addition, the ILO Convention includes a provision against discrimination of indigenous peoples (Article 3.1). This corresponds to the rationale of the reference to indigenous peoples in CESCR's General Comment No. 15, which stresses that "State Parties should ensure that there is adequate access to water ... for securing the livelihoods of indigenous peoples" (paras. 6 and 7; emphasis added). The 2007 UN Declaration on the Rights of Indigenous Peoples (UNDRIP), which is formally non-binding but is seen as interpreting preexisting international obligations in the specific context of indigenous peoples, ${ }^{8}$ makes explicit reference to water among the natural resources with which indigenous peoples have a right "to maintain and strengthen their distinctive spiritual relationship and to uphold their responsibilities to future generations," in relation in particular to "traditionally owned or otherwise occupied and used ... waters" (Article 25). From a procedural rights perspective, indigenous peoples have the right to be consulted "in order to obtain their free and informed consent prior to the approval of any project affecting their ... resources, particularly in connection

It has been suggested that some of the UNDRIP provisions form part of customary international law (International Law Association, Resolution No. 5/2012, Rights of Indigenous Peoples, 75th Conference held in Sofia, Bulgaria, 26 to 30 August 2012. Conclusions and Recommendations of the Committee on the Rights of Indigenous Peoples, para. 3). 
with the development, utilization or exploitation of water resources" (Article 32.2). In addition, indigenous peoples are to receive reasonable benefits from authorized activities affecting their territory or resources, and be provided access to effective remedies, including compensation, for harm caused by these activities (HRC, 2017, para. 51; see also Section 3.4). CESCR's General Comment No. 15 indicates that adequate access to water for securing the livelihoods of indigenous peoples is a necessity and must be facilitated by states in a non-discriminatory manner (GC 15, CESCR, 2002a, para. 7 and 12(c)), thereby underscoring the link between safeguarding natural resources and securing indigenous peoples' livelihoods and their right to food, as well as the relevance of procedural obligations.

General Comment No. 15 also indicates that adequate access to water for subsistence farming is a necessity and must also be facilitated by states in a non-discriminatory manner (GC 15, CESCR, 2002a, paras. 7 and 12(c)). It highlights States Parties' obligation to not deprive peoples of their means of subsistence (GC 15, CESCR, 2002a, para. 7; ICESCR, 1966, Article 1.2).

General Comment No. 15 refers to non-discrimination in a way that may provide a further link between the right to water and the right to food via the protection of related ecosystems. Access to water facilities and services is to be accessible for all "including the most vulnerable or marginalized sections of the population," giving special attention to those individuals and groups who have traditionally faced difficulty in exercising their right to water in rural areas and who should be protected from unlawful encroachment and pollution (GC 15, CESCR, 2002a, para. 16(c)). As highlighted by the Right to Food Guidelines, an adequate supply of water is required for preserving, or restoring the functioning of ecosystems, requiring that ecological needs be balanced with human needs for domestic, industrial, and agricultural uses (para. 16(c)). The same thinking emerges from the HLPE report, which highlights that:

[f]igures on country-level water availability, for example, mask in-country differences, discrimination between social groups as well as gendered differences.... Areas with high climate variability may experience several 
consecutive years of below average rainfall, with significant impacts on food production - particularly, but not only, in areas dependent on rainfed agriculture. ... Access to and use of water for FSN is informed by social, political and economic power relationships within countries, in water basins, and at the local level, as much as by infrastructure and rainfall therefore there is a need to improve water governance for food security and nutrition (HLPE, 2015, p. 46).

In addition, in the context of right to water, distinctions between indigenous peoples, pastoralists, and other local communities deserve further discussion. For example, General Comment No. 15 indicates that states should ensure adequate access to water for "subsistence farming and for securing the livelihoods of indigenous peoples" (para. 7), without drawing a distinction with water use for subsistence agriculture. The HLPE Report groups subsistence farming and indigenous peoples together, advising State Parties to the ICESCR to:

ensure that there is adequate access to water for subsistence farming and for securing livelihood needs of indigenous peoples, and that water should not be diverted for other needs at the costs of these communities (HLPE, 2015, p. 104-5).

This is an area that requires further clarification between the needs of subsistence farmers, pastoralists and indigenous peoples, as each may have different water requirements and different relationships with the land and water resources.

That said, states' obligations vis-à-vis indigenous peoples raise particularly complex issues with regard to the recognition of indigenous peoples' customary law. Customary laws play an important role in water management (Kurkuk, 2004). Most customary laws are unwritten, reflect traditions of peoples, and are highly adaptable depending on wider socioeconomic and political changes. Customary laws can differ widely across different cultures and ethnic groups. Local communities often consider customary law as the main rule of law because it has been used and evolved over hundreds of years (Burchi, 2005). In principle, customary water law can exist alongside statutory water law. However, from a practical point of view they often do overlap and interact across space 
and time (Burchi, 2005). When new water law is adopted, it can clash with existing, often informal rules of appropriation, use and protection of water. It is therefore important when establishing a formal water policy, to include unwritten - and sometimes perceived as informal - local customs and rules around water access and use. According to UNDRIP, states have an obligation to establish and implement, in conjunction with indigenous peoples and with their participation, a fair, independent and transparent process to give due recognition to indigenous peoples' laws and tenure systems, including in relation to resources that are traditionally owned or otherwise occupied or used by them (Article 27). This should be read in conjunction with international biodiversity law obligations in relation to indigenous peoples' customary laws (as discussed in Section 3.4). Notably, the relationship between customary and statutory laws may affect priority in water use (see Chapter 4).

\subsection{Preliminary conclusions}

All human rights are interconnected and the right to food derives from the right to an adequate standard of living, like the right to water. There are several cross-references also with the rights to life and health that point to convergence of meaning across these rights. This is in line with the principles of indivisibility, interdependence, and interrelatedness of human rights (Vienna Declaration, 1993, para. 5), which broadly refers to the cohesion and equal importance of all rights and points towards multiple and cross-cutting connections between different rights (Nickel, 2008). Cross-cutting connections between human rights standards are potentially significant, notably, if they affirm convergence in the meaning of rights. This suggests that interpretations of one right might be argued to inform the interpretation of another right, thus expanding the scope of meaning of both rights. Convergence of meaning might be evidenced, for example, by state practice expressed through state reporting mechanisms, or by cross-referencing within guiding documents or monitoring bodies' decisions (Quane, 2012). The cross-referencing between international legal materials on the right to water, other CESCR General Comments and reports of the Special Rapporteurs could be cited as evidence of 
convergence of meaning among the right to water and other human rights (right to an adequate standard of living, including right to housing and right to food, right to health and right to life), and thus points states to mutually supportive interpretations of these rights.

As a result of these contextual interpretations, insights from the right to food confirm that the right to water can be understood to extend beyond water for personal and domestic use to include access to water for food and agriculture. As the normative content of the right to water has developed in a similar way to the right to food (and other economic, social and cultural human rights), the right to food may also provide insights on how to interpret the normative content of the right to water in as far as it extends to food production and agriculture. Insights from the human rights of women and indigenous peoples serve to further clarify the content of the human right to water for food and agriculture, when water use for food production and agriculture is essential for the physical and cultural survival of indigenous peoples and/or for subsistence food production by rural women.

On that basis, a prioritization of water uses after the satisfaction of water for drinking and sanitation purposes can be proposed as follows:

- water for agricultural production (including pastoralism) that is necessary to prevent starvation;

- water for agricultural production that is necessary for indigenous peoples' livelihoods and cultural survival; and

- water for subsistence agriculture, particularly for disadvantaged and marginalized farmers and rural women.

As a result, a human rights-based approach requires that water allocation for the above-listed uses should be prioritized over other irrigation purposes. And there could of course be overlaps among the three categories outlined above. Equally, quantification (i.e. the amount of water necessary to produce food at subsistence levels) varies from one context to another culturally and environmentally, so the application of the prioritization needs to occur "at the level of individual (sub) 
catchment, where local needs can be specified with more precision" (WaterLex et al., 2017, para. 5.6).

These priorities thus need to be applied through a contextual assessment to also identify potential tensions between, for instance, indigenous peoples' water uses when their cultural survival is not at stake and water uses of other farmers whose subsistence is at stake. In addition, specific individuals within these groups (rural women, and vulnerable persons such as indigenous, children and persons with disability) need to receive particular attention. As discussed in the next chapter, additional considerations in this balancing exercise arise from other areas of international law. For instance, any prioritization needs to consider environmental sustainability as a precondition for the realization of the universal right to water through the application of an ecosystem approach to water management, and reliance on environmental impact assessments that integrate human rights, biodiversity and climate change concerns. 


\section{Insights from other relevant areas of international law}

The international human right to water for food production and agriculture should be interpreted and applied in light of states' other international commitments as a whole. It is a general principle of international law that states have to implement all their international obligations in good faith. This means that states also have to identify interpretative techniques and implementation approaches that avoid tensions between international regimes, and rather support approaches that maximize synergies across their international obligations.

The need for synergies between ensuring environmental sustainability of water management and the right to water for food and agriculture, for instance, is evident in the context of references to access to clean water under international human rights law (see Chapter 1). It is also implicit in the references to the role of the ecosystem approach to ensure continued, availability, quality and reliability of water for food security and nutrition (see Section 2.1.1) This chapter will consider this issue in more depth from the viewpoint of implementing international obligations arising from international law on transboundary watercourses, climate change and biodiversity. In addition, these areas of international law serve to clarify the duty to cooperate under the human right to water with specific regard to food production and agriculture.

Equally, tensions need to be avoided between measures for the protection and realization of the right to water for food production and agriculture and international economic law obligations related to the protection of foreign investment and the liberalization of international trade. As discussed in Chapter 1, the duty to cooperate under the human right to water implies that states conclude, interpret and apply other international agreements so as to avoid adverse impact on the right to water, including in other states. 
Notwithstanding these general obligations towards policy coherence, there may be contradictions in their national laws or international agreements that would interfere with the implementation of the right to water for food production and agriculture at the domestic level. Contradictions in national law should be identified and addressed, including through legal reform. If contradictions may arise between the human right to water for food and agriculture and, for instance, a bilateral investment agreement, states have to exert good-faith efforts to negotiate and conclude an international instrument that ensures mutual supportiveness between competing regimes. If such an agreement has nevertheless been concluded, states should disqualify interpretative solutions that maintain the contradiction (Pavoni, 2010). In particular, any negative impact on international human rights can only be permissible if it is pursuant to a valid public purpose, which cannot be a mere commercial interest, revenue-raising objective, or the conduct of activities that are primarily for private gain. In addition, the limitation must comply with standards of strict necessity and proportionality, be determined by law and be non-discriminatory.

The chapter will first look at areas of international law where tensions are likely to arise (investment and trade) and then at different areas of international environmental law (climate change and biodiversity) and international law on transboundary watercourses.

\subsection{International investment law}

States' obligations arising from the right to water may impinge upon their obligations under international investment law, which is mainly based on over 3000 international investment treaties (UNCTAD, 2018). Most of these treaties allow investors to bring claims against host states before international investor-state arbitration tribunals, should the investors consider that the state has violated its obligations under the relevant international investment treaties (Cotula, 2015). The right to water can be relevant to international investment law and to investorstate arbitrations initiated under international investment treaties in connection with concessions for water-related services and large-scale land investments that often allocate water rights to foreign investors. 
Concerns have been raised as to whether the adoption of international investment treaties and the threat of investor-state arbitrations initiated thereunder could restrict countries from acting in the public interest (the so-called 'regulatory chill') (Cotula, 2017), and in particular to encourage states to refrain from adopting laws relating to the right to water for fear of being sued by investors under applicable international investment treaties.

According to the UN Conference On Trade and Development (UNCTAD) Investment Dispute Settlement Navigator, ' 'water' (e.g. water collection, treatment, etc.) was an issue in 18 international arbitration cases. ${ }^{10}$ For instance, a Spanish foreign investor brought a claim against Argentina in connection with the termination of a concession for water and sewerage services pursuant to an international investment treaty (Urbaser S.A. $v$ Argentina, 2016). Argentina raised a counterclaim for damages against the investor based on its alleged "failure to provide the necessary investment into the Concession, thereby violating its commitments and its obligations under international law based on the human right to water" (Urbaser v Argentina, 2016, para. 36). Based on the wording of the investment treaty, the tribunal found that it had jurisdiction to hear the counterclaim but dismissed it on the merits. The tribunal found that private parties were obliged not to engage in activity that would have a negative impact on human rights. However, the tribunal could not find evidence that the alleged lack of investment into the concession had raised concerns about a breach of the right to water (Urbaser S.A. $v$ Argentina, 2016, paras. 1193, 1195, 1199, 1200 and 1211). International arbitral tribunals seldom consider human rights obligations and related counterclaims in detail and it will be interesting to see whether they continue to do so in future cases.

As far as agriculture is concerned, there has been a surge in large-scale land acquisitions, particularly since the $2007 / 2008$ food crisis, with

A database that contains information about known international arbitrations initiated by investors against states pursuant to IITs. [Online]. [Cited 4 December 2018]. http://investmentpolicyhub.unctad.org/ISDS

10 According to the UNCTAD database, there are currently 904 known treaty-based investor-state arbitrations. 
water often being a key aspect of large-scale land acquisitions (HLPE, 2015). Several states, including in Africa, have thus allocated water rights to foreign investors. They have done so, sometimes for very long periods of time and for as much as is required by the investor, to the detriment of local communities, including traditional/customary water users whose right to water can therefore be affected (Skinner and Cotula, 2011). EcoDevelopment in Europe $A B$ \& others $v$ United Republic of Tanzania is the first publicly known investor-state arbitration brought by a foreign investor resulting from the recent rise in large-scale land acquisitions. It is not yet clear whether human right issues have been raised in this arbitration, which was at a very early stage at the time of writing. It was reported that local communities that were displaced opposed the large sugarcane project and that the government cancelled it in 2016 (Williams, 2017).

The 2014 Principles for Responsible Investment in Agriculture and Food Systems, which were endorsed by the Committee on Food Security (CFS), an international and intergovernmental multi-stakeholder platform dealing with food security and nutrition issues. These Principles indicate that responsible investment in agriculture and food systems should respect existing and potential water uses (Principle 5). Accordingly, states involved in negotiations of international investment treaties and large-scale land acquisitions should ensure that appropriate guarantees are put in place to protect the right to water (see Section 1.4.4).

\subsection{International trade law}

States' obligations arising from international trade law may impinge upon the right to water to the extent that the states concerned are Members of the World Trade Organisation (WTO). This may, for example, occur when a state seeks to 'protect' the right to water from interference by third parties, such as private companies, through trade-restrictive measures. Accordingly, this section will look at four specific areas of interaction between WTO law and the right to water for food and agriculture: subsidies, virtual water, process and production methods, and bulk water transfers. 


\subsubsection{Water efficient agriculture - the role of subsidies}

International agricultural trade law does not prohibit states from providing financial support for agricultural research. This could undoubtedly include research into the production of agricultural goods in a less water-intensive way, so as to progressively realize the availability aspect of the right to water. While the WTO Agreement on Agriculture (AoA) regulates the granting of trade-distorting subsidies to domestic agricultural production (AoA, 1995), so-called 'green box' subsidies are exempt from reduction commitments. ${ }^{11}$ Included under the green box are expenditures for "research, including general research, research in connection with environmental programmes, and research programmes relating to particular products" (Annex 2, para. (a)), as long as it involves expenditures (or revenue foregone) in relation to programmes which provide services or benefits to agriculture or the rural community (not direct payments to producers or processors). ${ }^{12}$ In order to fall within the green box, the support must, "have no, or at most minimal, tradedistorting effects or effects on production," "shall be provided through a publicly-funded government programme", and "shall not have the effect of providing price support to producers" (Annex 2, para. (a)).

International trade law also takes a relatively permissive approach to the provision of 'water supply facilities' subsidies, which may fall within the green box of the WTO Agreement on Agriculture as infrastructural services (Annex 2, para. (g)). ${ }^{13}$ Many countries that have notified irrigation subsidies to the WTO have done so under the green box (Ahmad, 2017). Whether irrigation subsidies, as opposed to water supply subsidies in the form of infrastructural services, meet the requirements of the green box, has been questioned (Ahmad, 2017). Concern has also been expressed regarding the general environmental effects of irrigation subsidies, as well as the obvious incentives they create for inefficient water use (Ahmad, 2017). Within the context of progressive realization of the right to water, greater clarity on this issue would be required.

On a final point of note, discussion of water services raises the issue of WTO Members' obligations under the General Agreement on Trade in Services (GATS, 1995). The Office of the UN High Commissioner for 
Human Rights (OHCHR) has expressed concern regarding the potential human rights impacts of state commitments with respect to liberalization of services under the GATS (OHCHR, 2002). While there is nothing within the GATS requiring a state to liberalize water services, there is nevertheless a need for states to "regulate economic liberalization in the public interest" in accordance with the right to water, both in the context of multilateral commitments as well as in bilateral and regional trade agreements (Choukroune, 2017) ${ }^{14}$ By extension, the duty to cooperate under the human right to water implies that states conclude, interpret and apply international agreements in such a way as to avoid negative impacts on the right to water, including in other states (Chapter 1). States must therefore, protect their own regulatory flexibility, as well as respect that of other states, to ensure policy coherence between their commitments under regional trade agreements and their obligations arising from the human right to water (OHCHR, 2002, p. 4), as well as considering the articulation of the latter with the right to food..$^{15}$ It is clear that the duty to cooperate (Chapter 1 ) is underpinned by the principle of interconnectedness of all human rights, the realization of which is dependent upon relations between states, and which also extends to other policy areas.

\subsubsection{Process and production methods}

The question of mutual supportiveness also lies at the heart of another issue relevant to the position of the right to water within the multilateral trade regime; i.e. the fact that water is "grossly under-priced" (Hoekstra, 2010, p. 9). Addressing such under-pricing could implicate the relationship between trade and the right to water in a number of ways. For example, a state may want to enact regulations to promote water efficiency, both domestically as well as in respect of imported products (Brown, Weiss and Slobodian, 2014). Such regulation could take the form

\footnotetext{
14 It should be noted that the GATS contain in Article XIV a range of general exceptions similar to that of GATT Article XX. The policy space of states in this area is also likely to be impacted by international investment treaties, discussed in Section 3.1.

15 On the different approaches which have been taken to regulating water services under regional trade agreements, see Muller and Bellman, 2016, pp. 22-23.
} 
of a prohibition on the importation of goods produced in a particularly water inefficient way (Brown, Weiss and Slobodian, 2014). Undoubtedly, such an effort would be controversial and may in fact undermine the achievement of the right to food. As a result, states may hence wish to utilize less trade restrictive means to differentiate between goods based on the amount of water used in their production to encourage water efficient processes and production methods. It is not, however, altogether clear whether making a distinction between two otherwise 'like' products based on their virtual water content ${ }^{16}$ would be compliant with the non-discrimination obligations of the 1994 WTO General Agreement on Tariffs and Trade (GATT) (Brown, Weiss and Slobodian, 2014). ${ }^{17}$

Breaches of the GATT may potentially be justified under the Agreement's 'general exceptions' savings clause (e.g. GATT, 1994, Article XX). Two exceptions are likely to be of particular relevance; the first concerns measures "necessary to protect human, animal or plant life or health" (GATT, 1994, Article XX(b)), while the second is relevant to measures "relating to the conservation of exhaustible natural resources if such measures are made effective in conjunction with restrictions on domestic production or consumption" (GATT, 1994, Article XX(g)). In respect of this latter exception, an 'evolutionary' approach has been taken with the interpretation of the phrase "exhaustible natural resources," (United States America - Import Prohibitions on Certain Shrimp and Shrimp Products, 1998, para. 130), and it is at least arguable that water, depending upon its source, could be considered an exhaustible natural resource (Temmerman, 2017). In relation to the exception of dealing with "measures 'necessary to protect human, animal or plant life or health", the relationship between the right to water and the right to health may be of relevance given the prominence of health within the provision. The analysis of the 'necessity', or otherwise of the measure, will focus on "the importance of the interests at stake, the extent of the contribution [of

16 To the extent that the focus of the differentiation would be on the water used in the relevant process or production method, since the water content is not expressed in the final product itself. See also discussion below on trade in virtual water (Section 3.2.4).

17 Similar concerns arise with respect to the WTO Agreement on Technical Barriers Trade (TBT) (Brown, Weiss and Slobodian, 2014). 
the measure] to the achievement of the measure's objective, and its trade restrictiveness" (Brazil - Measures Affecting Imports of Retreated Tyres, 2008, para. 178). Whether a less trade-restrictive measure is available will also be considered (Brazil - Measures Affecting Imports of Retreated Tyres, 2008, para. 178). Furthermore, in order to be justified, the measure in question should not be applied as "a means of arbitrary or unjustifiable discrimination between countries where the same conditions prevail, or as a disguised restriction on international trade". A balance needs to be struck between a state's 'right to regulate' and the trading rights of other states (United States of America - Import Prohibitions on Certain Shrimp and Shrimp Products, 1998, para. 159). While yet to be tested in dispute settlement proceedings, clearly a well-designed measure which aimed to properly "price" water inputs in a non-discriminatory way on the basis of the requirements under international human rights law (see Chapters 1-2) and international environmental law (see Sections 3.4 and 3.5) could potentially pass muster under WTO law.

\subsubsection{Bulk water transfers}

While the focus so far has been on the interaction between the right to water with internal measures affecting trade, a water-scarce state may, in seeking to realize its obligations under the right to water, also wish to enact export measures to impede bulk water transfers (Turrini, 2015). While bulk water transfers between countries have occurred, they are not yet happening on a large scale but certainly could occur more widely in the future.

Discussions on export measures to impede bulk water transfers invariably raise questions of the compatibility of such measures with the rules of the GATT. However, a threshold issue to this analysis is whether water is a 'good' covered by the rules of the GATT. While an answer in the affirmative has generally been presumed (see discussion in McGarry, 2018), Turrini (2015) points out that there are a range of conceptual 
issues which arise with respect to this question and there is certainly no explicit answer within the text of the GATT. ${ }^{18}$

Assuming that water is indeed a good within the coverage of the GATT, it should be noted that there is a general prohibition on export prohibitions and restrictions (GATT, 1994, Article XI.1). This does not, however, apply to "export prohibitions or restrictions temporarily applied to prevent or relieve critical shortages of foodstuffs or other products essential to the exporting contracting party."19 The interpretation of this provision depends on the meaning ascribed to terms such as 'temporarily applied', 'products essential to' and 'critical shortages.'

Critical shortages relate to the notion of a crisis and have been defined as "deficiencies in quantity that are crucial, that amount to a situation of decisive importance, or that reach a vitally important or decisive stage, or a turning point" (China - Measures Related to the Exportation of Various Raw Materials, 2012, para. 326). "Products essential to" have been defined as those which are, "otherwise absolutely indispensable or necessary" (para. 323). Water in a water-scarce state would undoubtedly fall within this categorization. The term "temporarily applied" means of limited time or duration (para. 323). Accordingly, a long-term export restriction imposed by a state to prevent bulk transfers of water from that state to other states is unlikely to meet the requirement of 'temporarily applied' (Espa, 2015, p. 183), though temporary restrictions due to, for example, climatic events such as droughts would seemingly be covered

This is in contrast to, for example, the text of the 2016 Comprehensive Economic and Trade Agreement (CETA) between Canada and the European Union which sets out explicitly the legal status of water under Article 1.9:

1. The Parties recognize that water in its natural state, including water in lakes, rivers, reservoirs, aquifers and water basins, is not a good or a product. Therefore, only Chapters Twenty-Two (Trade and Sustainable Development) and Twenty-Four (Trade and Environment) apply to such water.

2. Each Party has the right to protect and preserve its natural water resources. Nothing in this Agreement obliges a Party to permit the commercial use of water for any purpose, including its withdrawal, extraction or diversion for export in bulk.

3. If a Party permits the commercial use of a specific water source, it shall do so in a manner consistent with this Agreement.

19 Pursuant to GATT Article XI:2(a). 
(Temmerman, 2017). Depending on the source of the water and the design of the measure, longer-term export restrictions may be justifiable under the general exceptions clause of the GATT relating to exhaustible natural resources (Temmerman, 2017). In addition, while export restrictions are generally prohibited under the GATT, export duties are generally permitted..$^{20} \mathrm{~A}$ high enough export duty on bulk water transfers could provide a significant disincentive to export of such water and thereby seemingly provide legal cover for water-scarce states to enact restrictive measures against bulk water transfers. ${ }^{21}$ However, export measures by one state may well spark similar measures in other states, and could also have a knock-on effect on food markets. ${ }^{22}$ In this scenario, the realization of the right to food could be undermined, particularly in respect of netfood importing developing states. This undoubtedly underlines the need to explore further, particularly in the context of the trade regime, and more broadly, the normative content of the right to water as it pertains to the right to food (HLPE, 2015). It also illustrates the need to review the mutual supportiveness of the trade regime with the realization of the right to water.

\subsubsection{Trade and virtual water}

To date, the right to water has found very little traction in WTO discussions. ${ }^{23}$ This is undoubtedly due in part to the fact that under WTO law, water is not generally conceived of as a tradable commodity (WTO, 2010) but instead, is seen "in terms of the water content of other commodities" (WTO, 2010, p. 5). This type of trade could offer the potential for an:

indirect and beneficial effect on domestic supplies of water. Exports of waterintensive products (e.g. agricultural goods) from regions of water abundance to regions where water is scarce can generate savings in importing countries by freeing up resources for other uses (WTO, 2010, p. 49).

\footnotetext{
Though there are some limited exceptions to this in respect of newer WTO Members. Though there are some limited exceptions to this in respect of newer WTO Members. This, for example, happened in the 2007/8 food price crisis; see generally Headey, 2011. A search at the date of writing (2018) of the WTO documents online facility using the term 'right to water' revealed one result.
} 
Such trade involves transfers of what has been termed 'virtual water,' that is, the 'water required to produce a commodity' (Hoekstra and Chapagain, 2007, p. 36).

Undoubtedly, such trade may allow an importing, water-scarce state to use its own domestic water supplies for purposes such as drinking, hygiene and sanitation (which is relevant for the availability dimension of the right to water discussed in Section 1.3). Indeed, the 2015 High Level Panel of Experts (HLPE) report on water for food security and nutrition underlined the importance of:

restor[ing] confidence in a rules-based, transparent and accountable multilateral trading system, taking into account the concerns and vulnerabilities of water-scarce countries that rely on international markets to meet their FSN (food security and nutrition) needs through food imports (HLPE, 2015, p. 11).

Accordingly, trade in products entailing virtual water may allow states to prioritize the allocation of domestic water supplies for 'personal and domestic uses' (GC 15, CESCR, 2002a, para. 12), while importing virtualwater products for other purposes such as food. This would seem to allude to the mutual supportiveness of the multilateral trade regime with the realization of the right to water, but the evidence for transfers of virtual water from water-secure states to water-scarce states is somewhat mixed: "Though researchers have found evidence that certain crops are traded from water-rich to water-poor countries, comprehensive global studies have found no connection between trade in virtual water and water scarcity." (Brown Weiss and Slobodian, 2014, p. 721). Considering virtual water trade and the interactions between such trade and the rules of the multilateral trade regime is important as changes to the latter, particularly in respect of agricultural trade liberalization, could, "inadvertently intensify the fresh water crisis" (Brown Weiss and Slobodian, 2014, p. 720). 


\subsection{International climate change law}

The international climate change legal regime is another area of international law that is relevant to the interface between the human right to water, agriculture and food. It has now been demonstrated that current climate change trends, due mainly to anthropogenic activities, negatively affect both water resources and food security (see Introduction).

Three scenarios can be envisioned. First, where climate change leads to increased water scarcity, food production can suffer as a consequence. Drawing attention to a UNDP's report warning that 600 million more people may be at risk of hunger due to climate change by 2080 (UNDP, 2007), the former Special Rapporteur on the Right to Food, Olivier De Schutter, stressed that levels of regional agricultural production are threatened by change in average temperatures through lack of available freshwater, including salinization of water sources for irrigation, caused by consequences related to climate change (HRC, 2010; see also Stern, 2007, p. 67). Second, unsustainable management of land resources can lead both to increased emissions of greenhouse gases (hence, climate change) and to a drain on water resources. The latter can both stem from freshwater present in surface water bodies or from groundwater (Siebert et al., 2010). In this respect, it is important to highlight that good groundwater governance can often be a very effective strategy to adapt to climate change, especially when economic activities, including agriculture production, combined with rising climate change, put pressure on surface water (Clifton et al., 2011). Accordingly, in 2015, Special Rapporteur on the Right to Food, Hilal Elver, emphasized that climate-induced impacts on sustainability of groundwater sources, based on an FAO estimate (FAO, 2006c) that groundwater sources provide 40 percent of water for irrigation, will "have a tremendous impact on the potential for food production" (UNGA, 2015).

Third, when climate change is added to the water-food nexus, competition over different water uses becomes a further governance challenge. In fact, climate change mitigation policies may lead states to focus on hydropower, which could, although not necessarily, divert 
water resources from other uses, including agriculture. Thus, UN Special Rapporteur, Hilal Elver, indicated that climate change mitigation and adaptation policies that affect water resources "must carefully consider competing water uses and the various implications for food security. Measures that mitigate one type of adverse impact could exacerbate another" (UNGA, 2015, para. 64; Searchinger et al., 2015). For instance, she indicated that "the construction of dams for hydroelectricity may affect water supply for agricultural activities downstream and also flood land that could otherwise be used for food production" (UNGA, 2015, para. 64).

Water use efficiency in line with SDG 6.4 will in turn be crucial in ensuring sustainable water use for agriculture in response to climate change. The UN Special Rapporteur on Human Rights and the Environment, John Knox, specifically elaborated on the connection between climate change and the human right to water from an international human rights law perspective. He highlighted the concern that "climate change poses an immediate and far-reaching threat to people and communities around the world and has adverse implications for the full enjoyment of human rights" as stated in a HRC 2011 resolution on climate change. He emphasized that climate change threatens the full enjoyment of the rights to water and food (HRC, 2016, para. 23). Knox thus recommended that based on the duty of international cooperation, states should fully implement all of the commitments they have made in relation to the Paris Agreement and strengthen their commitments in the future in order to ensure that global temperatures do not rise to levels that would impair the right to water. States should also adopt a legal and institutional framework that assists those within its jurisdiction to adapt to the unavoidable effects of climate change, exercising care to protect the rights of the most vulnerable (HRC, 2016).

From the perspective of the international climate change legal regime, the Paris Agreement (Paris Agreement, 2015) needs to be interpreted in conjunction with the 1992 United Nations Framework Convention on Climate Change (UNFCCC, 1993) and notably, the UNFCCC objective to address climate change in such a way that "ensures that food production is not threatened" (Paris Agreement, 2015, Article 2.1; and UNFCCC, 1993, 
Article 2). While the Paris Agreement does not explicitly refer to water or food in its operative provisions, its preamble, which provides elements to guide the interpretation of its operative provisions, "recognize[es] the fundamental priority of safeguarding food security and ending hunger, and the particular vulnerabilities of food production systems to the adverse impact of climate change."

In addition, the preamble of the Paris Agreement refers to human rights, without, however, explicitly mentioning the right to water (Mayer, 2016), as follows:

Acknowledging that climate change is a common concern of humankind, Parties should, when taking action to address climate change, respect, promote and consider their respective obligations on human rights, the right to health, the rights of indigenous peoples, local communities, migrants, children, persons with disabilities and people in vulnerable situations and the right to development, as well as gender equality, empowerment of women and intergenerational equity.

By referring to Parties' "respective obligations on human rights", it can be argued that a human right to water is implied in this language, as well as in the references to those rights that are tightly linked to the right to water, such as the right to health, and the rights of indigenous peoples and women (see Chapter 2). In all events, states remain responsible to respect their obligations arising from other international treaties under which the human right to water has been recognized. Accordingly, states need to duly take into account their obligations arising from the human right to water when dealing with climate change (HRC, 2011), for instance, by taking into account questions of accessibility of water for food and agriculture when implementing national policies for climate change mitigation, adaptation, and loss and damage. One way to do so is through procedural requirements for public participation in relevant decision-making processes.

Accordingly, UN Special Rapporteur Knox underscored that states have obligations to: i) assess and provide information about the effects of climate change, to ensure that climate decisions are made with the informed participation of the public; ii) provide for effective remedies 
for climate-related violations of the right to water, and iii) protect the rights of freedom of expression and association in relation to all climate actions, even when the rights are being exercised in opposition to projects supported by the authorities (HRC, 2016). In addition, existing or new impact assessments in the context of domestic climate policies should also incorporate specific concerns related to the right to water, which is foreseen under international human rights law (see Section 1.4). Finally, among the principles that underpin climate change adaptation policies, the Paris Agreement makes reference to traditional knowledge of indigenous peoples (Article 7.5), which is critical to ensuring consideration of the interface between water, food and agriculture where indigenous peoples and local communities are concerned (as discussed in Section 4.2). This understanding, however, rests on an understanding of the best scientific evidence, which is also included in the Paris Agreement, that includes both modern or western science and traditional knowledge.

\subsection{International biodiversity law}

As clarified by the UN Special Rapporteur on Human Rights and the Environment, John Knox, the full enjoyment of the right to water (as well as the rights to life, health and food) depends on the services provided by freshwater ecosystems, and the degradation and loss of biodiversity undermine the ability of human beings to access clean and safe water (HRC, 2017). Knox also highlighted the role of biodiversity in supporting the realization of the right of access to clean and safe water that can be used for food production (HRC, 2017, paras. 19-21; see also HRC, 2010, para. 9). International obligations to conserve and sustainably use biodiversity, including freshwater ecosystems (CBD, 1992), therefore also matter from a human rights perspective, as biodiversity degradation or loss can have negative impacts on the human right to water for food and agriculture. 
International biodiversity law is comprised of several treaties, ${ }^{24}$ but two are particularly relevant to the analysis of the interplay between the rights to water, food and agriculture: the Convention on Biological Diversity (CBD, 1992) and the Wetlands Convention (Ramsar, 1971).

The CBD has 196 Parties, so its coverage is universal, with the exception of the United States of America. The Convention aims at the conservation and sustainable use of biological resources (Article 1), and includes obligations of international cooperation, with particular reference to information-sharing and to scientific and technical cooperation (Articles 5, 17 and 18), as well as to regulate activities that may have significant adverse effects on biodiversity to avoid or minimize such impacts, adopteconomically and socially sound incentives for conservation and sustainable use, and require environmental impact assessments (Articles 6-8, 10-11 and 14). CBD Parties meet periodically and agree by consensus on decisions that provide further details on how to interpret and apply CBD obligations in particular contexts, such as in relation to inland waters and agriculture. The resulting soft-law guidance provides useful elements to better understand environmental sustainability as a pre-condition for the right to water for food and agriculture. For instance, CBD Parties have underscored the inter-connections between agricultural ecosystems and water use activities, and the need for more coherent implementation of the CBD work programmes on agricultural biodiversity and on inland water biodiversity consistent with the ecosystem approach (CBD COP Decision X/34, 2010, para. 15).

The ecosystem approach is the cornerstone of the CBD and has several dimensions (Morgera, 2017). First, it aims at integrating the management of land, water and living resources (CBD COP Decision V/6, 2000, Annex, para. 1 and Principle 5), prioritizing conservation and subjecting

$24 \quad$ Besides those cited below, the other biodiversity-related treaties are: the Convention on Conservation of Migratory Species, Bonn, 23 June 1979; the Convention on International Trade in Endangered Species of Wild Fauna and Flora, Washington D.C., 3 March 1973; the International Treaty on Plant Genetic Resources for Food and Agriculture, Madrid, 3 November 2001; the Convention Concerning the Protection of the World Cultural and Natural Heritage, Paris, 17 December 1972; the International Plant Protection Convention, Rome, 6 December 1951; the International Convention for the Regulation of Whaling, Washington, 2 December 1946. 
sustainable use to the limits of ecosystem functioning (CBD COP Decision V/6, 2000, Annex and Principles 5-6). Second, the ecosystem approach is based on adaptive management to deal with the complex and dynamic nature of ecosystems (CBD COP Decision V/6, 2000, Annex, paras. 2 and 4), integrating modern science and the traditional knowledge of indigenous peoples and local communities (CBD COP Decision V/6, 2000, Annex and Principle 11). Another key dimension of the ecosystem approach is its emphasis on equity, recognizing that human beings and their cultural diversity are an integral component of many ecosystems (CBD COP Decision V/6, 2000, para. 2). It underscores the need to understand and factor in societal choices, rights and interests of indigenous peoples and local communities, and intrinsic as well as tangible and intangible values attached to biodiversity, ultimately leading to a balance between local interests and the wider public interest (CBD COP Decision V/6, 2000, Annex and Principle 1). This can be read as reinforcing the need for contextual prioritization of water uses discussed at the end of Chapter 2.

Linked to this, the ecosystem approach calls for fair and equitable benefitsharing from ecosystem stewardship, as a reward for the integration of communities' traditional knowledge in planning and management (Morgera and Tsioumani, 2010; Morgera, 2016). This implies that the state is expected to provide procedural guarantees for community participation in decision-making and management planning, including on the use of water for food and agriculture. In addition, states are expected to adopt substantive measures for the legal recognition of communities' sustainable practices, as well as with the provision of guidance and support to improve the environmental sustainability of community practices, and with the proactive identification of opportunities for better or alternative livelihoods in these endeavours, with a view to facilitating understanding of, and compliance with, the law (Morgera and Tsioumani, 2010). This thus sheds further light on the requirement for "reasonable benefits" related to indigenous peoples' rights to natural resources and the interface between customary laws of indigenous peoples and national laws (see Section 2.2.2). Overall, these provisions provide indications on how to operationalize the right to water for food and agriculture at 
the intersection of indigenous peoples' rights in the context of water governance.

The Ramsar Convention originally placed emphasis on the conservation and wise use of wetlands primarily to provide habitat for migratory waterbirds, but over time Parties have recognized that wetlands are extremely important for biodiversity conservation in general and for the wellbeing of human communities. Under the Ramsar Convention, State Parties must designate wetlands in their territory for inclusion in a List of Wetlands of International Importance and they must also promote their conservation and wise use. Wetlands are defined as:

areas of marsh, fen, peatland or water, whether natural or artificial, permanent or temporary, with water that is static or flowing, fresh, brackish or salt, including areas of marine water, the depth of which at low tide does not exceed 6 metres (Article 1).

The concept of "wise use" refers to the "sustainable utilization for the benefit of humankind in a way compatible with the maintenance of the natural properties of the ecosystem" (Ramsar COP Recommendation C.3.3 (rev.), 1987). Parties have a general obligation to include wetland conservation considerations in their national landuse planning. As opposed to the CBD, where human rights language is generally avoided, Parties to the Ramsar Convention explicitly addressed linkages with the right to water, in recognition of the fact that wetland systems determine the quantity, quality and reliability of water supplies from that system, and changes to a wetland ecosystem can have profound impacts on water quality and availability for, inter alia, food production. Ramsar Parties thus stressed that:

The lack of recognition of the role of wetlands to be able to exercise fully the human right to water and poverty reduction, is an important factor in its reduction as well as in the modesty of the efforts invested in restoring wetlands (Ramsar COP Resolution XII.2, 2015, para. 24).

Regardless of whether international biodiversity law makes explicit references to the right to water, its obligations relate to the availability and quality of water as necessary factors to secure the right to water also 
for the purposes of food production and agriculture, including in relation to the human rights of indigenous peoples and local communities.

\subsubsection{General guidance}

The CBD State Parties were encouraged to ensure that their water allocation policies are based "on the need to achieve the sustainable availability of water adequate quantity and quality to support ecosystem functioning and the sustainable delivery of water-related or -dependent ecosystem services" (CBD COP Decision X/28, 2010, para. 17). The CBD Parties also noted that sustaining the availability of water quality is crucial for livelihoods and poverty eradication, and for the negative effects of climate change on the hydrological cycle and its groundwater component (CBD COP Decision X/28, 2010, paras. 1-3). They further underscored the need to investigate ways to enhance the ability of agricultural water use and drainage on ecosystems to provide water for food production for present and future generations (CBD COP Decision X/28, 2010, para. 18). To that end, CBD Parties have emphasized the need to:

i. enhance monitoring of the use of water in the agricultural sector, and to improve data collection, management and public access to monitoring data;

ii. develop policy frameworks for land use that enhance ecosystem services and functions linked to water provision that contribute to agricultural production, while also protecting, restoring and sustainably using biodiversity and promoting connectivity in the landscape; and

iii. use an appropriate mix of regulatory and incentive measures to increase the efficiency of use of water (CBD COP Decision XIII/3, 2016, paras. 17 (g), 28 and 32).

Under the Ramsar Convention, State Parties are to ensure that wetland management plans are developed within wider integrated catchment management approaches that duly acknowledge agricultural practices and policies that are compatible with, and enhance, positive incentives for wetland conservation and sustainable use goals (Ramsar COP Resolution 
X.15, 2008, para. 19). The Ramsar Convention and the CBD have also developed guidance on ensuring access to water for sustainable ricepaddies, keeping in mind that:

rice is grown in at least 114 countries worldwide and, as the staple diet for over half the world's population, has contributed to about 20 percent of the total calorie supply in the world (Ramsar COP Resolution X.31, 2008, para. 1; CBD COP Decision X/34, 2010, paras. 19-20).

Another key tool under the CBD and the Ramsar Convention is the environmental impact assessment (EIA) (CBD, 1992, Article 14; Ramsar COP Resolution X.17, 2008). The use of EIAs has been recommended with regard to water development projects and watershed activities, including agriculture, to gather adequate biological data to document effects on biodiversity, provide predictions on the effects of alternative project scenarios on ecosystems, consider the valuation of the goods and services of potentially affected ecosystems, and test predictions with well-designed samplingschemesthatcanadequately distinguish theeffects of anthropogenic activities from natural processes. These assessments are encouraged not only at the level of individual projects, but also at the level of watershed, catchment or river basin to assess cumulative effects of proposed developments (CBD COP Decision IV/4, 1998, para. (i)). An EIA is also expected to be carried out prior to ecosystem restoration activities supporting ecologically and economically sustainable agriculture, climate change mitigation and adaptation, and disaster risk reduction, in order to assess potential effects of restoration activities on the ecological function of adjacent waters (CBD COP Decision XIII/5, 2016). The UN Special Rapporteur on Human Rights and the Environment, John Knox, has underscored the importance of states' procedural obligations around EIA to ensure that the relationship between biodiversity and human rights, including the right to water and the right to food, are taken into account by: assessing the social and environmental impacts of all proposed projects and policies that may affect biodiversity; providing public information about biodiversity, including environmental and social assessments of proposals; ensuring that the relevant information is provided to those affected in a language that they understand; providing for and facilitate public participation in biodiversity-related decisions; 
and providing access to effective remedies for the loss and degradation of biodiversity (CBD COP Decision XIII/5, 2016, para. 28). These indications clarify the procedural dimensions of the right to water for food and agriculture integrating environmental sustainability considerations and contributing to an informed and participatory prioritization of water allocations (Chapters 1-2).

\subsubsection{Specific guidance concerning indigenous peoples and local communities}

On the basis of CBD obligations to respect, value and protect the traditional knowledge, and the sustainable customary use of biological resources of indigenous peoples (Section 2.2.2) and local communities (Articles 8(j) and 10(c)), CBD Parties have recognized that sustaining the availability and quality of water is particularly relevant in the context of livelihoods and poverty eradication. This can be read together with the interface between the right to water for food and agriculture and the human rights of indigenous peoples, farmers and rural women.

The CBD Parties have further recognized that indigenous peoples and local communities maintain a very close holistic, cultural and spiritual relationship with essential elements of biodiversity associated with the water cycle, as demonstrated in many cultural activities, including through indigenous languages, and can help to promote sustainable water management based on their traditional knowledge (CBD COP Decision X/33, 2010, preamble). CBD Parties have further recognized that healthy inland water ecosystems, and the traditional practices of sustainable use by indigenous peoples and local communities, are essential to achieving sustainable increases and improved resilience in the provision of food and livelihoods (CBD COP Decision XIII/3, 2016, para. 59). The ecosystem approach, in this connection, is consistent with the spiritual and cultural values as well as customary practices of many indigenous peoples and local communities and their traditional knowledge, innovations and practices. Accordingly, cultural, social, economic and ecological elements associated with the traditional management systems of lands, waters and territories by indigenous 
peoples and local communities and their involvement in managing these areas should thus be recognized, secured and protected (CBD COP Decision XII/12, 2014, para. 4), which contributes to the recognition of their customary laws (see Section 2.2.2). Thus, CBD Parties have underscored the need to promote and support the restoration of ecosystems that provide essential services to indigenous peoples and local communities, without causing harm to other ecosystems, in the context of the agricultural sector (CBD COP Decision XIII/3, 2016, paras. 17 (g), 28 and 32).

The CBD work programme on inland water biodiversity provides several indications of how states are expected to manage freshwater in light of these considerations, thereby shedding further light on the substantive and procedural dimensions of the right to water for food and agriculture. For instance, CBD Parties were encouraged to support indigenous peoples and local communities to:

- re-establish, develop and implement traditional approaches and/ or adaptive management approaches to conserve and sustain the use of the biodiversity of inland water ecosystems; and

- draw upon indigenous peoples' and local communities' knowledge, with their participation and prior informed consent, through effective collaboration with scientists, local stakeholders, planners, engineers and economists, in the planning and implementation of water resource developments (CBD COP Decision VII/4, 2004, paras. 8(c-e) and 1.1.4).

In addition, CBD Parties have agreed to promote the full and effective participation of indigenous peoples and local communities in the development of management plans and in the implementation of projects that may affect inland water biodiversity, as well as in policymaking, planning and implementation in accordance with national laws (CBD COP Decision VII/4, 2004, paras. 2.5.1 and 2.5.3). To that end, CBD Parties committed to put in place capacity-building measures to facilitate their participation and the application of their traditional knowledge, with their prior informed consent, in these processes (CBD COP Decision 
VII/4, 2004, para. 2.5.4). This can be read in conjunction with the procedural dimensions of the right to water for food and agriculture discussed in Section 1.4.3.

The CBD Parties agreed upon the Akwé: Kon Voluntary Guidelines for Socio-Cultural and Environmental Impact Assessment (Akwé: Kon Voluntary Guidelines, 2004). This soft-law instrument provides detailed guidance on the steps to be taken in carrying out an impact assessment for developments proposed to take place on, or which are likely to have an impact on, waters traditionally occupied or used by indigenous and local communities (CBD COP Decision VII/16, 2004, Annex), which contributes to clarify procedural obligations related to the human right to water for food and agriculture. Prior informed consent is expected to be sought at various phases of the impact assessment process, using culturally appropriate languages and processes, allocating sufficient time, and providing accurate, factual and legally correct information. Modifications to the initial development proposal require the additional prior informed consent of the affected indigenous peoples and local communities (CBD COP Decision VII/16, 2004, para. 53). The assessment should also serve to ensure that proposed development of traditional waters should lead to tangible benefits being accrued to such communities, including diversification of income-generating (economic) opportunities for small and medium-sized businesses (CBD COP Decision VII/16, 2004, para. 46), which could include food production and agriculture. These can be read in conjunction with the requirements for impact assessments, consent, and fair and equitable benefit-sharing under the ecosystem approach and the human rights of indigenous peoples (Morgera, 2019).

Furthermore, the Guidelines pay particular attention to issues related to agriculture. They call for assessing appropriately, taking into account indigenous peoples' and local communities' value systems, developments that particularly involve changes to traditional practices for food production (CBD COP Decision VII/16, 2004, para. 47). Food-related considerations also apply to the role of gender in socio-cultural and EIAs for developments on traditional waters. The Akwé: Kon Guidelines call for examining the potential impacts of a proposed development on women in the affected community with due regard to their role as providers of 
food and nurturers of families, community decision-makers and heads of households, as well as custodians of biodiversity and holders of particular elements of (gender-specific) traditional knowledge (CBD COP Decision VII/16, 2004, para. 48). This can contribute to the implementation of women's rights in the context of the context of the right to water for food and agriculture (see Section 2.2.1).

UN Special Rapporteur Knox also emphasized that non-indigenous communities who closely depend on nature for their material and cultural needs, such as members of marginalized ethnic groups, are especially vulnerable to actions that adversely affect ecosystems. States should therefore ensure that such actions, whether carried out by governments or private actors, do not impair the enjoyment of their rights to water. Therefore, states have heightened duties to ensure that these communities are able to enjoy the rights to information, participation, freedom of expression and association, and effective remedies in relation to actions that may adversely affect their relationship with the ecosystems on which they depend, as well as substantive rights to protection of the ecosystems themselves (HRC, 2017, paras. 52 and 71). These considerations, which are more developed in international biodiversity law than in international human rights law, underline the importance of the human right to water for food and agriculture also for particular groups that deserve special consideration and that share certain characteristics with indigenous peoples but do not self-identify as indigenous (Section 2.2.1).

\subsection{International law on transboundary watercourses}

International water law includes international law applicable to both transboundary surface water bodies (international watercourses) and groundwater (transboundary aquifers). Aquifers are comprised of a geological formation that contains the groundwater. When watercourses and aquifers straddle international borders, which is often the case, the human right to water takes on an additional international water law dimension (Leb, 2012). 
International water law is a composite patchwork of international legal instruments. Some of them are formally legally binding and others are non-binding recommendations and frameworks, with all of them reflecting elements of customary international law. None of these instruments makes a precise reference to the human right to water, but as the instruments must be read in light of current developments in international law (See Pulp Mills on the River Uruguay (Argentina $v$ Uruguay), 2010, p. 14), it is possible to identify provisions that can be interpreted in light of the human right to water for food and agriculture, particularly with regard to international cooperation (see Section 1.4.4).

\subsubsection{United Nations Convention on International Watercourses}

The 1997 UN Convention on the Law of Non-Navigational Uses of International Watercourses (UN Watercourses Convention) reflects to a great extent customary international law, and was therefore applied by the International Court of Justice even before its entry into force in 2014 (Gabcíkovo-Nagymoros Project Case (Hungary v Slovakia), 1997, paras. 78 and 85). The Convention sets out a detailed normative framework for countries sharing a watercourse ("a system of surface waters and groundwaters constituting, by virtue of their physical relationship, a unitary whole and normally flowing into a common terminus", Article 2(a)). It requires states sharing an international watercourse to cooperate and to enter into agreements for joint management of the watercourse (Articles 8 and 24), thus providing an avenue for implementing states' obligations arising from the human right to water through international cooperation (see Section 1.4.1). This is particularly relevant for ensuring environmentally sustainable water use as a precondition for the protection and realization of the right to water, in light of states' obligations under the UN Watercourses Convention to jointly:

prevent, reduce and control the pollution of an international watercourse that may cause significant harm to other watercourse states or to their environment, including harm to human health or safety, to the use of the waters for any beneficial purpose or to the living resources of the watercourse (Article 21.2). 
Similar provisions can be found in the 1995 Revised Protocol on Shared Watercourses in the Southern African Development Community (SADC), which requires state Parties, at the request of any one or more of them, to consult with a view to arriving at mutually agreeable measures and methods to prevent, reduce and control pollution of a shared watercourse (Article 4.2(b)(i)).

The obligation to cooperate under the UN Watercourses Convention sits alongside the obligation not to cause significant harm (Article 7), and a number of detailed procedural obligations, such as the obligation to share information and consult with, as well as notify other states (Articles 9 and 12-17), in the event planned activities are likely to cause significant harm, including sharing the results of any EIA. As discussed above, impactassessments can provide the means for an integrated consideration of impacts from the perspective of all relevant international obligations of a state, including international human rights, biodiversity and climate change law (see Sections 1.4, 3.3 and 3.4).

Furthermore, states also have the right to use the watercourse in an equitable and reasonable manner (Article 5). To that end, the UN Watercourses Convention lists factors that states need to take into account when determining what constitutes equitable and reasonable use (Article 6). One of these factors, "[t]he population dependent on the watercourse in each watercourse state" (Article 6.1(c)), arguably implies that the state in question would need to protect freshwater resources in order to fulfil its obligations under the human right to water, ${ }^{25}$ including in terms of extraterritorial obligations (see Section 1.4). Similar language can be found in the 2015 Agreement on Declaration of Principles of the Grand Ethiopian Renaissance Dam Project, which states that, "in ensuring equitable and reasonable utilization," states will take into account "the social and economic needs of the Basin States concerned" and "the population dependent on the resources" (Article IV). Another agreement that emanates from the same region, the 2010 Agreement on the Nile

$25 \quad$ The Berlin Rules indicate that vital human needs include "immediate sustenance of the household". The latter could include food, hence highlighting the water food nexus. The Berlin Rules also make reference to progressive realisation of the right of access to water. 
River Basin Cooperative Framework, which has not yet come into force, contains a similar provision obligating the parties to cooperate in order to "promote joint efforts to achieve social and economic development". (Article 3). References to the importance of "social and economic needs" and of "the population dependent on the [water] resources" can also be found in basin-specific transboundary water agreements, such as the 2003 Protocol for Sustainable Development of the Lake Victoria Basin (Article 5.3) and the 2008 Statute of the Interstate Commission for Water Coordination of Central Asia (Article 2.1), as well as in regional treaties, such as the 2000 SADC Revised Protocol on Shared Watercourses (Article 3.8(a)(ii) and (iii)). Another treaty that governs the operation of the water-related project, the Lesotho Highlands Water Project, requires South Africa and Lesotho to pay "due regard to the maintenance of the welfare of persons and communities immediately affected by the Project" (Maseur, 1986, Article 15).

The UN Watercourses Convention also requires determining "[t]he weight to be given to each factor ... by its importance in comparison with that of other relevant factors" and "[i]n determining what is a reasonable and equitable use, all relevant factors are to be considered together and a conclusion reached on the basis of the whole" (Article 6.3). The competition over different uses has always been a challenge in the management of shared water resources. The UN Watercourses Convention provides guidance in saying that "In the event of a conflict between uses of an international watercourse, it shall be resolved ... with special regard being given to the requirements of vital human needs" (Article 10.2). ${ }^{26}$ The commentary to the convention clarifies the intended meaning of the terms:

special attention is to be paid to providing sufficient water to sustain human life, including both drinking water and water required for the production of food in order to prevent starvation (ILC, 1994, p. 110).

Such an interpretation would give priority to water uses necessary to prevent death from thirst and starvation. A more expansive interpretation,

26 Emphasis added. 
based on the link between the right to water and the right to an adequate standard of living (see Chapters 1-2), is possible, but thus far, an international court has yet not embraced this expanded interpretation.

\subsubsection{United Nations Economic Commission for Europe Water Convention}

The 1992 UNECE Convention on the Protection and Use of Transboundary Watercourses and International Lakes is a legal instrument whose parties include states from Europe and Central Asia. The UNECE Water Convention entered into force in 1996 and in 2013 was opened for accession by any UN Member State (UNECE, 2013). For obvious reasons, the convention focused strongly on the problems that transboundary watercourses suffered in the UNECE region, especially pollution, through the obligations not to cause significant harm and to prevent pollution (Article 2). These obligations can be related to the human right to water for food and agriculture in relation to water quality, in as far as the duty to minimize pollution encompasses access to clean water. In addition, similar procedural obligations to those in the UN Watercourses Convention, such as duties to cooperate, exchange information and to avoid or mitigate a potentially significant transboundary impact, can also be found in the UNECE Water Convention (Articles 6, 9, 10, 13 and 14). These procedural obligations align with fulfilment of states' procedural obligations arising from the human right to water (see Section 1.4.3).

In terms of scope, the UNECE Water Convention is significantly wider than the UN Watercourses Convention as it applies to all transboundary waters, which are defined as "any surface or ground waters which mark, cross or are located on boundaries between two or more states" (Article 1.1). Quite progressively for its time, the UNECE Water Convention incorporates the concept of sustainable development in its general obligation to manage water resources "so that the needs of the present generation are met without compromising the ability of future generations to meet their own needs" (Article 2.5(c)). As noted in Section 2.1.1, sustainability is a key element of the normative content of the right to water. 
The UNECE Water Convention also applies to transboundary aquifers within its remit, which clarifies the duty to cooperate in relation to the right to water for food and agriculture. Since the convention was negotiated and drafted with mainly transboundary surface waters in mind, the non-binding 2013 Model Provisions on Transboundary Groundwaters (UNECE Model Provisions) were developed in 2012 in recognition that groundwater faces specific and unique issues. The Model Provisions call upon states to "take appropriate measures to prevent, control and reduce the pollution of transboundary groundwaters, especially those reserved for drinking water supply" (Provision 4.1). Means to prevent pollution of groundwater include the:

Establishment of protection zones, in particular in the most vulnerable/ critical parts of the recharge area of groundwaters, especially of groundwaters used or intended to be used for the provision of drinking water (Provision 5.2(a)).

These recommendations can be viewed as supporting the right to water which includes access to clean water. In addition, the Model Provisions call for environmental impact assessment procedures and for distribution of the resulting documentation in support of consultations among states (Provision 8.1). Sharing this information can provide the means for an integrated consideration of impacts from the perspective of all relevant international obligations of a state, including international human rights, biodiversity and climate change law (see Sections 1.4, 3.3 and 3.4). This also clarifies the procedural dimensions of the right to water (see Section 1.4.3).

The UNECE Water Convention also reiterates a general obligation to cooperate, which is strengthened by a mandatory provision requiring countries to enter into "bilateral or multilateral agreements or arrangements" (Article 9.1). Cooperation provides an avenue for implementing states' obligations arising from the human right to water, including extraterritorial ones, through international cooperation (see Chapter 1, Section 1.4). In particular, the convention encourages the establishment of joint monitoring programmes concerning water quality and quantity, draw up inventories, exchange information on pollution 
sources, elaborate emission limits for waste water and evaluate the effectiveness of control programmes (Article 9.2).

\subsubsection{United Nations Economic Commission for Europe Protocol on Water and Health}

The 1999 Protocol on Water and Health to the UNECE Water Convention entered into force on 4 August 2005 and to-date has 36 signatories and 26 parties. Its objective is to:

promote at all appropriate levels ... the protection of human health and wellbeing ... through improving water management, including the protection of water ecosystems, and through preventing, controlling and reducing waterrelated disease (Article 1).

In line with the principles enshrined in the CEDAW and the ILO Indigenous and Tribal Peoples' Convention (see Section 2.2), the protocol provides that "equitable access to water ... should be provided for all members of the population, especially those who suffer a disadvantage or social exclusion" (Article 5(1)). Implementation is achieved through an obligation upon State Parties to set national targets relating to various aspects of access to water (Article 6), in addition to ongoing monitoring and data collection to track progress towards meeting targets (Article 7).

While the Protocol does not expressly mention the human right to water, its objective closely parallels the three factors required to secure the right to water as set out in General Comment No. 15 on the Normative Content of the Right to Water addressed in Section 1.2, namely: water availability, quality and accessibility. Furthermore, attainment of the objective of the Protocol can be considered an essential component to protect individuals' rights to an adequate standard of living, freedom from hunger and the enjoyment of the highest attainable standard of physical and mental health, as enshrined in Articles 11 and 12 of the 1966 ICESR. Read together with these two instruments, the Protocol therefore represents one of the strongest examples in international water law of an approach to transboundary water issues that integrates international law with a human rights-based approach. Read together with the UNECE 
Water Convention and other UNECE water-related instruments, the UNECE water regime has had a significant impact in driving forward regional cooperation on transboundary water issues, and has in turn had an impact upon the procedural aspects of international water law (Moynihan, 2020).

\subsubsection{Draft Articles on Transboundary Aquifers}

Among other influences, the UNECE Model Provisions drew on the 2008 UN Draft Articles on the Law of Transboundary Aquifers of the International Law Commission (Draft Articles, UNGA Res 63/124, 2008). In their current format, annexed to a UNGA Resolution, the Draft Articles are not legally binding. States are encouraged to consider them as guidance when they develop joint legal agreements or arrangements in the management of transboundary aquifers (UNGA Res 63/124, 2008; Eckstein and Sindico, 2014). The Draft Articles pay specific attention to the protection of groundwater-dependent ecosystems (Article 10), protection of recharge and discharge zones (Article 11), and precaution in the management of transboundary aquifers (Article 12). This can be related to the human right to water in as far as it encompasses access to clean water. Like other global instruments, the Draft Articles also specify the obligation to cooperate (Article 7) and to not cause significant harm (Article 6), which provide an avenue for implementing states' obligations arising from the human right to water through international cooperation (see Section 1.4.4).

Procedural obligations in the Draft Articles such as the exchange of information roughly mirror those of the UN Water Convention, albeit with less detail. In addition, the Draft Articles call for impact assessments when a state:

has reasonable grounds for believing that a particular planned activity in its territory may affect a transboundary aquifer or aquifer system and thereby may have a significant adverse effect upon another state (Article 15.1). 
As noted above, this can provide the means for an integrated consideration of impacts from the perspective of all relevant international obligations of a state, including international human rights, biodiversity and climate change law (see Sections 1.4, 3.3 and 3.4).

The Draft Articles also include the right to use the transboundary aquifer in an equitable and reasonable manner (Articles 4-5), with a list of factors for determining whether a use of a transboundary aquifer is equitable and reasonable. Mirroring the UN Watercourses Convention, one of the factors is " $[t]$ he population dependent on the aquifer or aquifer system in each aquifer state" (Article 5.1(a)), and vital human needs are to be given "special regard" when weighing the factors of equitable and reasonable utilization. Furthermore, the Draft Articles add that "[W] here an emergency poses a threat to vital human needs, aquifer states, notwithstanding Articles 4 and 6, may take measures that are strictly necessary to meet such needs" (Article 17.3). Therefore, meeting vital human needs may be considered as carrying more weight in the Draft Articles than in the UN Watercourses Convention (Leb, 2012).

The ILC only made a short reference to a restrictive interpretation of "vital human needs" as being strongly linked to the right to life, rather than also to the right to an adequate standard of living (Article 10.2). While this was a missed opportunity, it is in the application of the Draft Articles through specific transboundary aquifer agreements and arrangements that the human right approach to vital human needs will be tested. A promising development in this connection can be found in the 2014 Iullemeden-Taoudeni/Tanezrouft Aquifer Systems MOU (not yet in force), which includes a reference to "the right to water" not only in its preamble, ${ }^{27}$ but as one of the factors according to which Parties will determine whether a use of the groundwater of the IullemedenTaoudeni/Tanezrouft Aquifer Systems is equitable and reasonable (Article 13(i)), ${ }^{28}$ with reference to populations that are dependent on

\footnotetext{
27 "Recognizing the fundamental right of each individual for access to water."

28 "The use of ITAS water resources should take into account the principle of equitable and reasonable utilization. To this end, the following circumstances and relevant' factors shall be taken into account: The right of access to water for ITAS people."
} 
the aquifer (Article 13(c)). The MOU further adopts the language of the UN Watercourses Convention and the Draft Articles in indicating that in weighing different kinds of uses of a transboundary aquifer or aquifer system, "special regard shall be given to vital human needs", although in "determining what is equitable and reasonable utilization, all relevant factors are to be considered together and a conclusion reached on the basis of all the factors" (Article 5.2) ${ }^{29}$ The preamble of the MOU includes a reference to a Consultation Mechanism that aims, inter alia, to formulate the rules relating to the conservation and protection of the environment and aquatic ecosystems against degradation and pollution, in accordance with the objectives of sustainable development (Article 3(d)). The MOU also foresees that states consider the establishment of harmonized water quality standards to prevent and control groundwater pollution (Article 27), which can provide an avenue for implementing states' obligations arising from the human right to water through international cooperation (see Section 1.4.4).

\subsection{Preliminary conclusions}

The international human right to water for food production and agriculture should be interpreted and applied in light of states' other international commitments as a whole. While respecting other international commitments, however, states have obligations to conclude new international agreements that do not adversely impact on the right to water, such as international trade and investment treaties (see Section 1.3.4). So, states should be aware of the need to retain regulatory space domestically to meet their obligations in respect of the progressive realization of the right to water within their own territory when negotiating trade and investment treaties. In addition, as part of the extraterritorial obligations arising from the human right to water, states must conclude, interpret and apply international trade and investment treaties so as to avoid adverse impact on the right to water in other states.

International environmental law obligations provide indications on how to ensure environmentally sustainable water management and 
use as a precondition for the realization of the human right to water. In addition, these obligations contribute to clarify the procedural dimensions of the right to water for food and agriculture, notably with regard to environmental and socio-cultural impact assessments, that can feed into the contextual prioritization of water uses discussed in Section 2.3. International law on transboundary watercourses, climate change and biodiversity also serve to clarify the duty to cooperate under the human right to water with specific regard to food production and agriculture. International biodiversity law, notably its guidance on the ecosystem approach, supports states in taking a holistic approach to water management with a view to also integrating human needs related to health and rural livelihoods, with particular attention to indigenous peoples and local communities. In particular, the CBD and the Ramsar Conventions have adopted specific guidance on respecting and integrating the knowledge systems of indigenous peoples and local communities and taking into account their customary laws (see Sections 2.2.2 and 3.4), although such integration remains subject to respect of relevant international obligations, such as human rights and environmental sustainability standards.

While international law on transboundary watercourses does not generally address the human right to water, a contextual and evolutionary interpretation of its obligations may allow it to:

- rely on the cooperation obligations and specific mechanisms created under international watercourses agreements to implement the duty to cooperate as part of the human right to water under international human rights law, notably with regard to ensuring environmental sustainability of water use; and

- give special regard to "vital human needs" in the context of obligations related to the equitable and reasonable use of transboundary water by integrating consideration of the obligations arising from the human rights to water.

In terms of extraterritorial obligations arising from the right to water, even if international water law instruments are focused on interstate procedural obligations, State Parties to relevant human rights 
instruments should take into account their obligations to avoid adverse impacts on the right to water of individuals in other countries in the context of collaborative transboundary water management arrangements (see Section 1.4.1). Finally, a combined reading of international water and biodiversity law allows to clarify the obligations of states vis-à-vis indigenous peoples and local communities that come into play in relation to transboundary water management.

International guidance on human rights with regard to subsistence farmers, however, is less well developed. As noted in Section 2.1, the Declaration on the Rights of Peasants and Other People Working in Rural Areas includes a section on the right to water for farming, livestock keeping and also includes securing other water-related livelihoods. Focus is placed on equitable access, including in customary and communitybased water management systems, on a non-discriminatory basis. It pays particular attention to disadvantaged or marginalized groups, such as nomadic pastoralists, workers on plantations, migrants, regardless of their legal status, and persons living in irregular or informal settlements. Article 21.3 of the Declaration provides that states shall "take measures to guarantee affordable water for personal, domestic and productive uses" ${ }^{30}$ Additionally, international guidance adopted by consensus under the CBD and the Ramsar Convention with regard to non-indigenous local communities also provide guidance on recognizing and protecting traditional or community-based approaches to water management, and integrating communities' knowledge in impact assessments and management plans. This is with a view to fairly and equitably sharing with these communities the benefits arising from sustainable water use, and promoting their full and effective participation in management, development approach, as well as policy-making related to water, and facilitating their cooperation with all others involved in water governance (see Section 2.2.2).

Ultimately, international environmental law and international law on transboundary watercourses contribute to clarify the context for the prioritization of water uses related to food production and agriculture,

30 Emphasis added. 
after the satisfaction of water for drinking and sanitation purposes (see Section 2.3). A cross-cutting argument to the proposed prioritization is that in all these instances the role of water for ecological integrity should be a key consideration, given its vital nature in ensuring the sustainability of water use and the sustainable use of other resources for the realization of key inter-linked human rights. This is even more true in light of the additional strains on water resources arising from the negative impacts of climate change (Windfuhr, 2003). It could thus be argued that preference should be given among water uses for agricultural and food production to those uses that are environmentally sustainable and that therefore also contribute to the realization of the universal right to water. The ecological aspect in the prioritization of water use appears to have attracted little attention (Gleick, 1998), however, possibly because the drafters of the key international human rights instruments relevant for the human right to water did not realize water would be a scarce resource in the future (Cahill, 2005). Proposals have been made for separating water for drinking, water for food, and water for ecosystems to facilitate clearer targets and monitoring (Brooks, 2007). As already discussed in this study, other areas of international law contribute to clarify the interface between the right to water and environmental sustainability, supporting states in implementing all relevant obligations in a mutually supportive manner (see Section 3.4-3.5).

In view of all the different factors that play out in the proposed prioritization, it appears useful to recall the procedural dimension of the right to water, and similar guarantees of transparency, participation and accountability under international environmental law (see Sections 1.4 and 3.4). As underscored under the Ramsar Convention, "[w]hilst it will not be possible to please all stakeholders in any water allocation decision," by ensuring a transparent process in the decisionmaking, "no demand should be ignored" (Ramsar COP Resolution VIII.1, 2002). Equally, the process of implementation of prioritization decision should be transparent, and decision-makers should be accountable to an independent body that is accessible by all stakeholders (Ramsar COP Resolution VIII.1, 2002). Potential incompatibility between environmental sustainability and the realization of the universal right 
to water should also be addressed in the context of a transparent and participatory process with a view to determining a reasonable balance between the legitimate public interest aim to ensure environmental sustainability (including for the purposes of protecting the right to water for food and agriculture in the future) and the means chosen to achieve such aim. To that end, the use of environmental and socio-cultural impact assessments that integrate concerns arising from international human rights, biodiversity and climate change law, as well as the traditional knowledge of indigenous peoples and local communities, is key (see Section 3.6), together with participatory adaptive management and monitoring in following up on the outcomes of these assessments. 



\section{Implications of the right to water for food and agriculture}

This part will consider key concepts that link the above-discussed areas of international law with national law, in order to identify challenges and opportunities in implementing the various international obligations that contribute to clarify and support the right to water for food and agriculture, setting the basis for the proposed prioritization of water uses (see Section 2.3). The first concept is the human rights-based approach (HRBA), which is a well-established method of developing policies and practices that assist in the fulfilment of human rights. The second concept is integrated water resources management, which is an approach to water governance that is widely used by water professionals and policy makers. The connections between the human right to water and the concepts of land tenure and water rights will then be explored. Finally, the section will conclude with a consideration of the implications of this analysis for national law frameworks regulating water. ${ }^{31}$

\subsection{Human rights-based approach}

The 2003 UN Statement of Common Understanding on Human RightsBased Approaches to Development Cooperation and Programming (UNDG, 2003) remains the most comprehensive statement of a UNwide understanding of the HRBA. According to that statement, the HRBA provides a framework for understanding relationships between the holders of human rights and duty bearers of those rights, which is based on the recognition of rights and duties (as opposed to charitable assistance). The HRBAs are driven not only by the tangible outcomes sought, but by the explicit aim of development activities which should be to contribute, at every stage, to the realization of specific human rights (UNDG, 2003). 
In the context of its mandate, FAO has defined HRBA to mean that:

The HRBA is generally defined as a conceptual framework of human development that is normatively based on international human rights standards and operationally directed at promoting and protecting human rights. It is analysed and implemented with "three lenses": (1) the achievement of human rights as the overall objective or guiding framework of development and/or emergency-related initiatives; (2) respecting the human rights principles of participation, accountability, non-discrimination, transparency, human dignity, empowerment and the rule of law (PANTHER) in the design, implementation, monitoring and evaluation of programmes or projects, in order to improve targeting, efficiency, effectiveness and quality of outcomes; (3) the promotion of rights, duties, responsibilities and accountability mechanisms by developing the capacity of duty bearers to meet their obligations and of right holders to claim their rights (FAO, 2017).

A key part of a HRBA should be a focus on integrating procedures aimed at building the capacity of rights-holders to claim their rights and of duty bearers to realize those rights (UNDG, 2003). These procedural dimensions should give rise to a focus on transparency and accountability of duty bearers and on empowerment and participation of rights holders in a way that combines bottom-up and top-down approaches (UNDG, 2003).

Other key elements of a HRBA are: processes to identify causes of gaps in rights realization, monitoring and evaluation of interventions that are guided by human rights principles, and using recommendations of human rights monitoring bodies and mechanisms to inform interventions (such as those on the right to water and other relevant human rights discussed in Chapter 1). Some research indicates that the use of HRBAs can facilitate decentralized ownership of development processes and can positively promote sustainable change (Crawford, 2007; Schmitz, 2012). In the context of effective water governance, applying a HRBA requires emphasizing citizen participation, transparency and openness to public scrutiny of decisions, equitable access to water to improve well-being for all groups in society, public accountability, coherence of policies and 
government actions across all aspects of water resources management, and responsiveness to stakeholders' needs and demands (FAO, 2009), which reflects an open, participatory and accountable process of water use prioritization discussed above (Section 2.3).

It is crucial to note that there are distinct correlations between the six principles of HRBA mentioned above and the general procedural dimensions of the human right to water set out in Chapter 1, including the human rights principles of "participation and empowerment, accountability, non-discrimination and equality, transparency and access to information" (HRC, 2013b, para. 15). In a practical sense, there are various ways in which the HRBA principles can already be found in domestic legislation in the context of water for food and agriculture. This is neatly demonstrated in Kenya's Water Resource Management Rules 2007, which provides for the establishment and legal recognition of Water Resource Users Associations. In accordance with HRBA principles and procedural rights, the public authority responsible for granting water use licences is obligated to consult with the relevant Association(s) on every licence application, and permit the Association 30 days to respond (Section 28). Furthermore, the law will not recognize such an Association unless they have a "constitution conducive to collaborative management of the water resources of a particular resource and which promotes public participation, conflict mitigation, gender main-streaming and environmental sustainability" (Section 10.1). This represents one mechanism to allow stakeholders, including subsistence farmers, women, youth and indigenous peoples, to participate in decision-making concerning the management of water resources.

Additionally, environmental and socio-cultural impact assessment represents a valuable practical tool through which to facilitate stakeholder participation in decision-making and consideration of all interests and stakeholders (see Chapter 3). For example, in the Plurinational State of Bolivia's 1992 Law on the Environment, all activities, whether public or private, must undergo an environmental impact assessment of a level that is proportionate to the potential impacts of the activity (Article 25). Crucially, in Article 24 of the country's General Regulation of Environmental Management, for the purposes of the EIA, 
"environment" includes physical, chemical, biological, social and cultural aspects, thus allowing for consideration of impacts of the activity upon not only biodiversity and water resources in a biological sense, but also their importance for other stakeholders.

\subsection{Integrated water resources management}

Some principles of HRBA can find resonance in the concept of integrated water resource management (IWRM). The Global Water Partnership defines IWRM as:

based on the equitable and efficient management and sustainable use of water and recognizes that water is an integral part of the ecosystem, a natural resource, and a social and economic good, whose quantity and quality determine the nature of its utilisation (GWP, 2017).

As part of this approach, IWRM requires integration of land- and water-related aspects at the level of the catchment basin or sub-basin (Agenda 21, 1992). The 1992 Dublin Statement (see Section 1.1), which established four principles for water management, are often cited as the foundational principles for IWRM, emphasized, among other things, participatory approaches to water development and management, and gender considerations.

Agenda 21 provided further details on the concept of IWRM (Agenda 21, 1992). Four principal objectives were identified, which are significant for a HRBA and the different dimensions of the human right to water to:

- promote a dynamic, interactive, iterative and multi-sectoral approach to water resources management, including the identification and protection of potential sources of freshwater supply, which integrates technological, socio-economic, environmental and human health considerations;

- plan for the sustainable and rational utilization, protection, conservation and management of water resources based on community needs and priorities within the framework of national economic development policy; 
- design, implement and evaluate projects and programmes that are both economically efficient and socially appropriate within clearly defined strategies, based on an approach of full public participation, including that of women, youth, indigenous people and local communities in water management policy-making and decision-making; and

- identify and strengthen or develop, as required, in particular in developing countries, the appropriate institutional, legal and financial mechanisms to ensure that water policy and its implementation are a catalyst for sustainable social progress and economic growth (Agenda 21, 1992).

The IWRM is now a broadly accepted concept in water governance and following the Johannesburg Summit in 2002, IWRM was linked to a plan of action, as a consequence of which status reports on implementation are prepared by UNEP (UNEP, 2012). The IWRM principles can be linked to several key features of international law previously discussed in this study, such as the indivisibility of human rights, the necessity of effectively prioritizing water allocation to respond to vulnerable groups' needs, the procedural dimensions of the right to water, and the consideration of environmental sustainability as a precondition for the realization of the right to water (discussed in Chapters 23).

\subsection{A human rights-based approach to integrated water resource management}

Despite overlaps between the principles of HRBA and IWRM, the interconnections between the two concepts have only been recently explored (UNDP-SWI-WGF, 2012). Both are grounded in concern for equity and emphasize procedural rights, as well as integrated decision-making (WaterLex et al., 2017). But as opposed to the IWRM, a HRBA is not only driven by meeting individuals' needs, but by the explicit recognition of rights holders' entitlements and corresponding obligations. The HRBA can thus give a normative framework to IWRM, so that both concepts can be applied in mutually supportive ways. Particularly, a HRBA can assist in balancing the potentially complex and competing aims of IWRM in order 
to meet basic standards of living through water management (UNDPSWI-WGF, 2012). In turn, HRBA can benefit from the systems-oriented approach of IWRM, as the latter facilitates analysing the entirety of the regulatory framework of water in the context of human rights, including land governance.

The Stockholm International Water Institute identified four critical aspects of applying a HRBA to IWRM at a national level, which emphasizes the procedural considerations of the human right to water (FAO, 2009; see Section 1.4.3):

- state ownership and leadership to promote an HRBA to water allocation;

- enshrinement of human rights principles in national law;

- capacity-building through strengthening the ability of civil society and communities to use an HRBA to water resource management; and

- increasing citizen engagement and awareness of both rights of rights holders and responsibilities of duty-bearers (UNDP-SWIWGF, 2012; see also UNDP, 2006).

A HRBA to IWRM is thus the key to allocating and protecting the actual availability of water for priority water uses that are necessary to realize the right to food, as well as the right to water, with a view to avoiding negative impacts on the livelihoods of indigenous peoples and other subsistence farmers (WaterLex et al., 2017, para. 5.6).

\subsubsection{The interaction between the human right to water, water rights and land tenure}

Application of a HRBA to IWRM necessarily includes a consideration of land tenure and water rights at the national level, as well as of customary land and water rights (WaterLex et al., 2017, para. 5.6) (see Section 1.1). There are a several key interactions to consider in this context. 
First, the relationship between water rights and the right to water for food and agriculture should be understood. Water rights impact upon the efficiency, environmental sustainability, equity, empowerment and conflict resolution in water use (Meinzen-Dick and Nkonya, 2007). Similar to other types of resources, water rights can be broadly defined as public, private, common and open access, according to who has the right, against whom the right can be enforced, and the decision-making power to allocate water resources. The word "right" regarding water in this context has different meanings, including state granted licences to use water for a particular purpose, and property rights to use water arising by virtue of, or connected with, land ownership or customary water rights (FAO, 2006b; UNDP-SWI-WGF, 2012). Further, in each individual legal system, there may be a combination of water rights that can interact and co-exist in complex ways. For example, in the United Kingdom of Great Britain and Northern Ireland (Scotland), when a landowner wishes to use a river on their land, national regulations implementing the European Union's Water Framework Directive may require the landowner to obtain a licence from the Scottish Environmental Protection Agency. ${ }^{32}$ However, regardless of the grant of this licence, there are still property rights that entitle downstream and upstream landowners along a river to object to any operation which materially interferes with the flow of the river, except when use of water is for domestic purposes. In the particular case of Scotland, however, domestic purposes include subsistence agriculture (Robbie, 2015), which therefore allows consideration of the right to water for food and agriculture (see Chapter 2).

Second, the interface between land tenure rights and water rights may have impacts on the realization of the right to water, not just for personal and domestic use, but also for food and agriculture. This comes to the fore particularly in connection with schemes relevant to food and agriculture, such as water irrigation projects and water points for groups including pastoralists (Cotula, 2008a; FAO, 2009). Such schemes may

United Kingdom of Great Britain and Northern Ireland, Water Environment (Controlled Activities) (Scotland) Regulations (S.S.I No. 209 of 2011), issued under the Water Environment and Water Services (Scotland) Act (Asp 3 of 2003), which implements the EU Directive 2000/60/EC (23 October 2000). 
give rise to significant issues, including suppressing land tenure rights, reallocating irrigated plots to other users and providing open access to water points thereby potentially conflicting with pre-existing rights to use water (Cotula, 2008; FAO, 2008). Such schemes can undermine rights of access to water resulting in conflicts among, for instance, farmers and pastoralists, and can adversely affect women and vulnerable groups (Cotula, 2008a; FAO, 2008).

It should also be borne in mind that private property finds a degree of protection in international human rights law, and may contribute to the protection of foreign investors (see Section 3.1). It is therefore possible for human rights to provide conflicting protections. Nonetheless, an example of a solution to such issues within national law can be found in Article 373(II) of the Plurinational State of Bolivia's Constitution, which provides that:

water resources in all their states, surface and subterraneous, constitute finite, vulnerable, strategic resources, and serve a social, cultural and environmental function. These resources cannot be the object of private appropriation and they, as well as water services, shall not be given as concessions and are subject to a system of licensing, registration and authorization pursuant to the law.

Article 374 further goes on to provide that:

the state shall protect and guarantee the priority use of water for life. It is the duty of the state to manage, regulate, protect and plan the adequate and sustainable use of water resources, with social participation, guaranteeing access to water for all the habitants.

While it is not expressly stated, this wording "water for life" suggests that it may also include the human rights to water for food and agriculture.

Despite the clear link between land tenure rights and water rights, the Voluntary Guidelines on the Responsible Governance of Tenure of Land, Fisheries and Forests in the Context of National Food Security (VGGT) do not explicitly address water. Initially, 'water tenure' was to be included within their scope (FAO, 2016). Although water was left out of the VGGT text $(F A O, 2012)$, the preface to the VGGT highlights the fact 
that "the responsible governance of tenure of land, fisheries and forests is inextricably linked with access to and management of other natural resources, such as water" and that:

[w] hile recognizing the existence of different models and systems of governance of these natural resources under national contexts, states may wish to take the governance of these associated natural resources into account in their implementation of [the VGGT].

Accordingly, the 2014 CFS Principles for Responsible Investment in Agriculture and Food Systems have clarified that the VGGT are relevant to ensure that responsible investments in agriculture and food respect "existing and potential water uses" (Principle 5; see Sections 3.1 and 4.4).

\subsubsection{Considerations related to customary land and water rights}

Land tenure and water rights are also cardinal in the customary laws of indigenous peoples and other communities and raise particular challenges for the realization of the right to water for food and agriculture (see Sections 2.2.2 and 3.4.2). In customary laws, water is usually considered as a common or community resource, but other individuals may have private rights over a specific water resource under water rights established in national law (see Section 4.3.1). This therefore raises the issue that water rights must be studied within the wider context of legal pluralism (von Benda-Beckmann, 1995). In addition, customary and religious laws, which play an important role in the allocation of water rights, are in their turn also deeply plural. For example, communities from different ethnic and religious background may live together but may have very different customs and traditions in relation to the allocation of water. Studying the allocation of water rights from the perspective of legal pluralism also draws the attention that water rights also come with duties for their holders (von Benda-Beckmann, 1995).

In relation to customary and community-based water rights systems, there can be strong notion that everyone is entitled to water for basic domestic needs. This makes for an interesting link between formal legal frameworks protecting the right to water and informal law such as 
customary or religious laws (Hellum, Kameri-Mbote, and van Koppen, 2015). These basic use rights can be very flexible, socially negotiable and highly adaptable depending on local, social and environmental circumstances. Further, local water allocation systems can also be robust and resilient, as access to water is maintained through an intricate set of social and reciprocal relations. Chiefs, elders, local authorities and specific groups or individuals may play an important role in the management of water resources and their influence may extend to control rights. The fairness and effectiveness of these locally-based management rules, however, can vary depending on whether participatory decision-making tools are in place. There can be informal arrangements governing the use of the resource in this context that can be vulnerable to unequal power relations and discriminatory practices (Alden Wily et al., 2017). Nevertheless, while formal water management reform agendas aspire to improve access to water in fragile communities, they may be less robust, dynamic and livelihood-oriented in comparison to informal communitybased water management arrangements (Meizen-Dick and Nkonya, 2007; van Koppen, 2017).

There are different ways to recognize customary water law. Reference to customary law could be made in written water law. ${ }^{33}$ Customary water rights for selected purposes such as domestic use, irrigation and watering livestock could be recognized as statutory rights. ${ }^{34}$ Statutory water law could also recognize the power of traditional authorities to regulate traditional water rights. ${ }^{35}$ When these approaches are not feasible and/ or water management may impact negatively upon traditional uses and rights, statutory water law can provide for compensation rights. ${ }^{36}$ In any case, tackling the relationship between statutory water laws with customs

\footnotetext{
33 For example, the Namibian Water Resources Management Act (2004) explicitly acknowledges customary water rights and practices.

$34 \quad$ The Nigerian Water Resources Decree (1993) is a good example where the customary right of occupancy of land includes a right to draw water from under the ground or from an adjacent stream without charge for domestic purposes, watering livestock and for personal irrigation.

35 For example, the Burkina Faso Water Code (1983) and the Niger Water Code (1993) recognizes the power of local authorities to govern water resources.

36 For example, Papua New Guinea's Water Resources Act (1982) provided for compensation if groundwater development negatively affected local communities' use and access to water.
} 
and traditional practices remains a difficult balancing act (Burchi, 2005). Compensation, however, should only be provided after relevant human rights guarantees have been followed, namely: overriding public purpose (not merely an economic interest), strict necessity and proportionality, legal basis and be non-discriminatory. Even where there is no limitation to customary rights, indigenous peoples and local communities should share fairly and equitably in any benefits deriving from management decisions impacting on water resources traditionally owned or used by them (see Sections 2.2.2 and 3.4.2). For this reason, customary users and other rights holders need to participate in a meaningful way in the decision-making processes around policy, planning and day-to-day water management of national water allocation plans (see Sections 2.2.2 and 3.4.2), which is in line with the procedural content of the human right to water and the ecosystem approach (see Section 3.4).

\subsection{Relevant examples in national law}

This section provides an overview of existing provisions in national law that respond to the international obligations and guidance discussed so far on the human rights to water for food and agriculture. There are actually few examples that can be identified in this connection. They relate to: constitutional provisions, principles, prioritization, interinstitutional coordination and decentralization.

When considering the implications of the above discussion for national law, human rights studies often focus on the relationship between individuals and the state and begin with a discussion of the right to water within a constitutional context. As human rights obligations are largely state-centred, focus on the constitution is understandable. Indeed, a growing number of states now guarantee the right to water in their constitutions (FAO, 2009; Chávarro, 2015), including the 
Plurinational State of Bolivia, ${ }^{37}$ South Africa, ${ }^{38}$ and Uruguay. ${ }^{39}$ Various other countries, including Ethiopia, ${ }^{40}$ the Gambia, ${ }^{41}$ and Zambia ${ }^{42}$ stop short of proclaiming access to water to be a human right, but nonetheless included it as a directive principle for government actions alongside other requirements of an adequate standard of living such as food (FAO, 2009). A key distinction to draw between these two approaches is that only the former creates rights that may be enforced by the courts (FAO, 2009). Even where the human right to water is not explicitly protected in the constitution, it can be inferred from other rights. For example, the 1949 Constitution of India (amended 2012) does not explicitly mention the right to water but the Indian Supreme Court has affirmed the human right to water derives from the right to life contained in Article 21 of the Constitution.

In the 1991 case of Subhash Kumar vs State Of Bihar, the Supreme Court of India held:

Right to life is a fundamental right under Article 21 of the Constitution and it includes the right of enjoyment of pollution free water and air for full enjoyment of life.

37 Constitution of the Plurinational State of Bolivia (2009): Article 16 "Every person has the right to water and food."

38 Constitution of the Republic of South Africa (1996): Section 27.1 "Everyone has the right to have access to (a) health care services, including reproductive health care; (b) sufficient food and water; and (c) social security, including if they are unable to support themselves and their dependants, appropriate social assistance."

39 Constitution of Uruguay (1966, last amended 2004): Article 47.1 "The access to potable water and the access to sanitation, constitute fundamental human rights."

$40 \quad$ Constitution of the Federal Democratic Republic of Ethiopia (1994): Article 90.1 "to the extent that the country's resources permit, policies shall aim to provide all Ethiopians access to public health and education, clean water, housing, food and social security."

$41 \quad$ Constitution of the Republic of Gambia (1997): Section 216.4 "The State shall endeavour to facilitate equal access to clear and safe water, adequate health and medical services, habitable shelter, sufficient food and security to all persons."

42 Constitution of Zambia (1996): Article 112(d) "the State shall endeavour to provide clean and safe water, adequate medical and health facilities and decent shelter for all persons, and take measures to constantly improve such facilities and amenities." 
The Kerala High Court, in the 2006 case of Vishala Kochi Kudivella Samrakshana Samithi v State of Kerala, decided:

We have no hesitation to hold that failure of the State to provide safe drinking water to the citizens in adequate quantities would amount to violation of the fundamental right to life enshrined in Article 21 of the Constitution of India and would be a violation of human rights.

However, enshrining human rights principles in national law must go further than the constitutional level; rules are needed in all areas of law and policy that impact on water use and availability. There are a range of non-mutually exclusive legal avenues through which this may be achieved, ranging from further elaboration of constitutional rights, to mechanisms designed to achieve equitable management of water resources. Article 5 of the Armenian Water Code 2002, for example, includes "the provision of food and national security" among the basic principles to inform the management, use and protection of water resources. As another example, Article 1 of France's Law 2006 on Water and Aquatic Environments provides that "the use of water belongs to each and every physical person, for their food and hygiene ...". Functional mechanisms that may be used include the prioritization of different kinds of water uses. Such provisions can be found in many national legal frameworks, including Spain's 2001 Royal Legislative Decree Approving the Consolidated Text of Water Law (Article 60.3), Armenia's 2002 Water Code (Article 31) and Greece's 2003 Law on Water Protection and Management (Article 10.1). In each of these jurisdictions, use of water for subsistence purposes is granted top priority, and in the instance of Spain and Greece, agriculture and irrigation are ranked second. However, categories used for prioritization are often general in nature and, for example, do not distinguish between water use for subsistence agriculture and production of cash crops (van Koppen and Schreiner, 2018).

The need to enshrine human rights principles in legal instruments beyond the constitution is also well demonstrated by the process by which South Africa moved towards a HRBA to water management, which involved the drafting of various new policy instruments such as the 
Free Basic Water Strategy, ${ }^{43}$ and two major pieces of legislation in the form of the Water Services Act 1997 and the National Water Act 1998. Together these acts govern a broad range of issues related to water such as outlining the rights and responsibilities of the state's trusteeship in relation to water, provisions about the requirements for licences for water use and a regulatory framework for water services.

An additional mechanism could be through implementation of a tiered licensing system that applies more stringent checks and controls upon the activities of high impact users, as is applied in Kenya (van Koppen and Schreiner, 2018). Furthermore, due process within licensing systems can also ensure consideration of the needs of small and vulnerable users (van Koppen and Schreiner, 2018). This is demonstrated in the case of Malawi's Water Resources Act 2013, which requires that consideration must be given to traditional communities, and customary rights and practices when determining whether to issue a water use licence. Article 5 of the Armenian Water Code further includes "the provision of food and national security" among the basic principles to inform the management, use and protection of water resources.

In addition to enshrining human rights principles at multiple levels of national law, it is important that each state takes an integrated approach to water governance. As water is central to many different sectors, coordination between different policy areas and institutions such as planning, agriculture and energy is crucial. For instance, all 13 Latin American and Caribbean countries surveyed by the OECD had coordination mechanisms between policy areas and vertically within policy areas to support integrated water governance (Akhmouch, 2012). In these countries, there are, however, remaining gaps in governance which are hindered by accountability and funding gaps (Akhmouch, 2012). Another example of cross-sectoral coordination is provided by Armenia's Water Code, Article 8 of which prescribes that the Armenian National Water Council shall comprise representatives from state governance bodies responsible for "environment protection, agriculture,

$43 \quad$ See a discussion of implementing this policy here: South African Department of Water Affairs and Forestry (DWAF) Free Basic Water Guidelines and Regulations, 2002. 
urban development, state property management, public health, finance and economy."

At the level of individual households, it can be viewed as part of the state's obligations arising from the human right to water, that national authorities should not disconnect households for non-payment of water charges where there is no other accessible and affordable water source (HRC, 2007; FAO 2009b). The practice of disconnection of water supply resulting from non-payment of water charges has been the subject of litigation and successful challenge in jurisdictions such as South Africa, ${ }^{44}$ Colombia (Flor Enid Jimenez de Correa v Empresas Públicas de Medellin, 2007) and United States of America (New York) (Pilchen v City of Auburn, $N Y, 2010)$. Further, it is being increasingly recognized in the courts in various jurisdictions that a state has positive obligations to adopt measures to provide water to its population, especially the poor and indigenous communities. ${ }^{45}$ These obligations should also be linked to the prioritization of water uses in light of the human right to water for food and agriculture (see Section 4.3).

The human rights discussions of water often advocate a licensing system governed by an entity that is suitably empowered to manage the resource holistically and to balance various competing interests appropriately, based on a participatory approach (WGF, 2012). An important point to consider in this regard is Principle 2 of the 1992 Dublin Statement (Section 1.1), which states that a key component of the participatory approach is that decisions are taken at the "lowest appropriate level", with consultation of stakeholders and water users. The same idea has been encapsulated in the ecosystem approach under the Convention on Biological Diversity (see Section 3.4). Dublin Statement Principle 1

\footnotetext{
$44 \quad$ See, for example, Residents of Bon Vista Mansions v Southern Metropolitan Local Council, 2002 (6) BCLR 625 (W) (2002) and City of Cape Town v Strümpher, ZASCA 54 (2012).

45 See, for example, in relation to Argentina: Asociación Civil por la Igualdad y la Justicia c/ Gobierno de la Ciudad de Buenos Aires Cámara de Apelaciones en lo Contencioso Administrativo y Tributario (Ciudad Autónoma de Buenos Aires) 18 July 2007; Defensor del Pueblo de la Nación c/ Estado Nacional y Provincia del Chaco D.587.XLIII [Suprema Corte 2007]; and South Africa: Government of the Republic of South Africa and Others $v$ Grootboom and Others CCT11/00, [2000] ZACC [Constitutional Court 2000]. For a general summary of the human right to water in national courts see: WASH United \& WaterLex, 2014.
} 
further indicates that, in the case of water resources, the lowest appropriate scale for management may be at the level of "catchment areas or aquifers." Strengthening local engagement is also recommended within the context of a HRBA to IWRM. Local governance has been noted as an effective way to manage shared resources (Ostrom, 2009). Decentralization of aspects of water governance allows empowerment and participation of the local community, enables the management of the resource to better respond to local needs and conditions as well as providing effective monitoring and enforcement mechanisms (HLPE, 2015). The High Council for Food, Agriculture and Rural Areas has recognized successful management of water across different levels to improve irrigation for agriculture in Ethiopia and Morocco (CGAAER, 2012; HLPE, 2015). In Ethiopia, in the area of Alifif, traditional knowledge was used to reformulate the rules for water allocation in coordination with traditional water committees which allowed for agricultural diversification and increased resilience to drought (see Section 2.2.2). However, this local engagement has to be implemented while ensuring there is not an increase in governance fragmentation and policy incoherence. Therefore, national priorities need to be effectively communicated and implemented through multiple levels of governance.

Indeed, in recent decades many countries have moved towards decentralized models of water management through establishment of management bodies at the basin- or aquifer-level (FAO, 2009). For example, in Spain's Consolidated Text of the Water Law (Article 24(a)) and Kazakhstan's Water Code 2003 (Article 40.2.6), determinations on issuance of water use licences can be made by basin management authorities. In Kenya's Water Act (Sections 12(d) and 27(b)) and Malawi's Water Resources Act 2013 (Sections 10.1(c) and 29.1(b)), the final determination is made by a centralized authority, upon receipt of advice from the relevant decentralized water management authority. In determining the appropriate level for decision-making, it is important to consider the capacity of the country in question. If capacity is limited, it may not be feasible to fully decentralize decision-making, in which case centralized governance, with appropriate inputs from devolved actors, may in fact be the lowest appropriate level. Regardless of the level at 
which decision-making is held, it is key that comprehensive consultation is undertaken and that decision-making processes are holistic, taking account of all water users and sectors concerned. For example, although final decision-making authority regarding water use licences lies with decentralized authorities in Spain and a centralized authority in Malawi, in both instances the decision-making bodies comprise representatives from a range of sectors including agriculture, environment, public health and finance. ${ }^{46}$

A licence-based approach also provides convenient opportunities to undertake environmental and socio-cultural impact assessments (discussed in Section 3.4.1). Indeed, a licence-based system was the approach adopted by South Africa when transitioning to a HRBA following the end of apartheid, although using water for reasonable domestic purposes does not require a licence (see Chapter 2). However, even where there is a system that has largely abolished property rights to water that are connected to landownership (see Section 4.3), permits are mainly granted to landowners or lawful occupiers (FAO, 2008), and this mechanism can discriminate against indigenous peoples and women (Joy et al., 2011). Non-owners may still have difficulties with accessing water, due to the fact that the water is located on land to which they do not have lawful access. Therefore, within a licence system, ownership of land and the possibility of excluding non-owners from access to water is still a live issue. As a result, it is important to consider the broader framework of land tenure when developing policies designed to fulfil the human right to water. The combination of a HRBA and IWRM, however, allows human rights to be considered when land tenure laws and policies are being applied and reformed. For these reasons, it is important to ground the considerations made in the previous sections on the content of the right to water for food and agriculture in the context of national water

Spain's Royal Legislative Decree No. 1/2001 Approving the Consolidated Text of the Water law (2001), Article 27, and Malawi's Water Resources Act (No. 2 of 2013), Section 8.3, respectively. It is worth noting that the discretion of Spanish authorities is partially constrained by existing obligations under European Union law. For example, Article 11.5 of the EU Water Framework Directive (Directive 2000/60/EC) mandates Member States to revisit water use authorizations in the event that the water body for which the authorization has been issued is not on track to achieve environmental objectives specified in Article 4 of the Directive. 
and land governance. There are multiple ways in which the connection between water and land can be recognized in law, and a recent study of 100 countries shows a wide variety of existing legal frameworks protecting community water rights regardless of land tenure (Alden Wily et al., 2017).

Where a state has established a licence system for water use, it is important that there be flexibility within the licence arrangement to provide for re-prioritization in the event of a change in national conditions. To promote transparency and accountability, such discretionary power on the part of the licensing authority should also be twinned with appropriate procedural safeguards, such as a duty of the decision-making authority to provide reasons for decisions in writing and to allow the aggrieved party access to an expedient, affordable and independent appeal mechanism. Care needs to be taken not to merely reallocate to politically and economically powerful users (Meinzen-Dick and Nkonya, 2005). An extreme example of this can be shown in a case, from Ecuador, where the state declared a state of emergency due to water scarcity caused by drought in order to take measures to protect the right of access to water for human consumption and agricultural activities. ${ }^{47}$ Indeed, in the constitutional reform which took place in Ecuador in 2008, the order of priorities for water allocation was outlined as i) water for domestic use, ii) irrigation for food sovereignty, iii) ecological flow and iv) productive activities (Harris and Roa-García, 2013).

\subsection{Implications for reviewing (and reforming) national law}

One of the greatest challenges facing national legislators and policy makers is determining how to consolidate and effectively implement internationally recognized norms and standards into nationally applicable and enforceable rules. The difficulty of this task is exacerbated by increasing global challenges and pressures on natural resources that have widely diverse impacts and implications in the different jurisdictions across the world. However, international human rights

${ }_{47}$ Ecuador's Caso no 0006-10-EE [2010] 0010-10-SEE-CC (Corte Constitucional 8 April 2010). 
jurisprudence and guidance from other areas of international law (see Chapters 1-3) provide a normative framework within which national regulatory systems can be placed in the context of a human rights-based approach to IWRM. This entails considering the regulation of the multidimensional nature of water and the multiple functions water plays in providing an adequate standard of living, supporting ecosystems and assisting economic development, across all the sectors that affect water resources and across multiple levels of governance.

Due to the compound challenges facing water use and availability in different contexts, there is no one national system which can be promoted as a template for all other jurisdictions. However, a HRBA to IWRM may provide a useful starting point to tackle these challenges in a systematic manner at the national level.

The content of the human right to water for food and agriculture needs to be reflected in national laws that affect water management, with particular attention to disadvantaged and marginalized farmers, subsistence farming, rural women and indigenous peoples. National law should thus be reviewed to ensure priority for water use in agriculture and pastoralism when necessary to prevent starvation, as well as in subsistence and/or traditional agriculture that is essential for securing livelihoods and cultural practices.

Analysing the entirety of the regulatory framework in light of the IWRM, should thus be done in light of relevant international human rights and environmental obligations, including the need for improving water access to vulnerable populations and women, and for ensuring participation of local communities in sustainable and integrated land and water management. This requires assessing whether legal and institutional mechanisms target water availability and quality specifically to support subsistence and traditional agriculture, as well as ecosystem functioning and the sustainable delivery of water-related or -dependent ecosystem services, while taking into account the negative effects of climate change on the hydrological cycle and its groundwater component. If provisions already exist in national legislation to this end, care should be taken to prevent the introduction of retrogressive measures, including in times of 
crisis and budget cuts. In addition, national legislation needs to support an adaptive management of freshwater resources and their ecosystems, based on enhanced monitoring of the use of water in the agricultural sector, improved data collection and public access to monitoring data. This includes consideration of wetland conservation and of ecosystem restoration activities supporting ecologically and economically sustainable agriculture, while providing essential services to indigenous peoples and local communities.

National legislation on decision-making on water allocation, and water management more generally, needs to follow the ecosystem approach through integrative and adaptive conservation and sustainable use of inland water ecosystems. A legislative review may also need to occur in other areas of the law. Sustainable, non-discriminatory, gender-sensitive and secure access to such resources may be ensured by undertaking land reform, for instance. More generally, contradictions in national law should be identified and addressed, including through legal reform. In addition, procedural requirements need to take into account barriers that may derive from lack of integration across decisions in different water use sectors by separate departments, so that cumulative impacts can also be considered.

Procedural guarantees for the right to water for food and agriculture also require careful inclusion in national legal framework on water management and potentially in other areas (land ownership, land use planning) that can affect availability or quality of water for food and agriculture. Access to information, public participation in decisionmaking and access to effective remedies are essential for a meaningful contextual prioritization of water uses. The public has a right to seek, receive and impart information about water issues access such as: water-related issues and human health, proposed water projects, law and policies affecting or potentially impacting water resources, including information about the effects of climate change and of proposed climate change response measures; and threats to the environment and possible response measures. This is considered essential so that rightsholders can participate meaningfully in decision-making processes, monitoring, environmental and socio-cultural impact assessment, and enforcement 
mechanisms for the right to water for food and agriculture. New mechanisms may be needed to provide effective remedy where existing mechanisms are inadequate, including to provide for effective remedies for violations of the right to water for food and agriculture and protect the rights of freedom of expression and association even when the rights are being exercised in opposition to projects supported by authorities (including climate-related projects, as climate change responses also need to take into account potential negative impacts on human rights and biodiversity). These are essential requirements for a meaningful contextual prioritization of water uses to also identify potential tensions between, for instance, indigenous peoples' water uses when their cultural survival is not at stake and water uses of other farmers whose subsistence is at stake. In addition, specific individuals within these groups (rural women, and vulnerable persons such as children and persons with disability) need to receive particular attention.

National legislation thus needs to require environmental and sociocultural impact assessments with regard to water development projects and watershed activities, as well as climate change response measures. These assessments are encouraged not only at the level of individual projects, but also at the level of watershed, catchment or river basin to assess cumulative effects of proposed developments. To support a human right to water for food and agriculture, these assessments should provide the means for an integrated consideration of impacts from the perspective of all relevant international obligations of a state, including international human rights, biodiversity and climate change law. Environmental and socio-cultural impact assessments should thus focus on:

1. continued availability, quality and reliability of water for food security and nutrition, including of freshwater ecosystems;

2. the effects of water and land-related policies, such as large-scale land acquisitions, on the progressive realization of these rights;

3. potential climate change impacts on water for agricultural production (e.g. salinization of water sources for irrigation), including on sustainability of groundwater sources; 
4. unsustainable management of land resources leading to increased emissions of greenhouse gases and a drain on water resources; and

5. climate change mitigation policies through hydropower diverting water resources from agriculture.

National provisions on environmental and socio-cultural impact assessments need to make specific provisions on the need to integrate the traditional knowledge of indigenous peoples and local communities, and to follow specific procedures when proposed developments may affect water resources traditionally owned or occupied by indigenous peoples and local communities, in line with the 2004 CBD Akwé: Kon Guidelines, that have been largely recognized by a variety of international human rights bodies as a helpful reference in this connection. Accordingly, environmental and socio-cultural impact assessments should equally address:

1. potential negative impacts on indigenous peoples' and local communities' traditional systems of water tenure and use, and traditional practices for food production, including opportunities for elders to pass on knowledge to youth;

2. potential negative impacts on women as providers of food, nurturers of families and traditional knowledge holders; and

3. not only negative impacts, but also tangible benefits for these communities, including diversification of income-generating (economic) opportunities for small and medium-sized businesses, including in agriculture and food production.

More generally, national law should ensure that it pays special attention to those individuals and groups who have traditionally faced difficulties in exercising their right to water for food and agriculture. With regard to the interface between the human right to water for food and agriculture and women's rights, specific provisions may be needed so that women are not excluded from decision-making processes concerning water resources and entitlements, and gender is main-streamed in collaborative management of water resources. 
With regard to indigenous peoples and local communities (including traditional farmers), decisions on water-related management affecting waters traditionally owned or used by these groups need to be preceded by an appropriate environmental and socio-cultural impact assessment, as well as free, prior informed consent, fair and equitable benefit-sharing, and access to effective remedies. Free, prior informed consent is expected to be sought at various phases of the impact assessment process, using culturally appropriate languages and processes, allocating sufficient time, and providing accurate, factual and legally correct information. Compensation for any negative impact on their human rights to water for food and agriculture should be made clearly, subject to a valid public purpose stated in law, strict necessity and proportionality, and be non-discriminatory. National legislation should also clearly provide for consideration of the rights, interests and knowledge of indigenous peoples and local communities on decision-making on water allocation, and water management, based on their fully and effective participation and effective collaboration with scientists, local stakeholders, planners, engineers and economists, in the planning and implementation of water resource development. States are thus expected to provide specific procedural guarantees for community participation in decision-making and management planning that may affect the use of water for food and agriculture, as well as in the development of management plans and in the implementation of projects that may affect inland water biodiversity, as well as in policy-making. This includes creating clear obligations for public authorities to provide capacity-building opportunities for communities to effectively make use of their rights in these contexts. In addition, states are expected to adopt substantive measures for the legal recognition of communities' sustainable practices, provide guidance and support to improve the environmental sustainability of community practices, and identify, together with communities, opportunities for better or alternative livelihoods.

For these purposes, prioritization of water uses needs to occur at the level of individual (sub)catchment, where local needs can be specified with more precision. Such contextual prioritization and identification of concerns around the right to water for food and agriculture can also 
100 The right to water for food and agriculture

contribute to develop an explicit justification for potentially tradedistortive measures, such as water pricing, that is based on relevant international human rights and environmental law. 


\section{Conclusion}

Although the normative content of the right to water has developed primarily in terms of access to safe drinking water and sanitation, and water for personal and domestic use, it extends to water for food and agricultural production in its interactions with other human rights (notably the right to food, which is of particular importance for rural women and indigenous peoples). Such contextual reading of the right to water is supported by the fact that both the right to water and the right to food are inextricably connected to the right to an adequate standard of living and understood to be inherent also in the right to health and the right to life.

As a result, water uses after the satisfaction of water for drinking, sanitation, washing and cooking purposes should be prioritized as follows:

- water for agricultural production (including pastoralism) that is necessary to prevent starvation;

- water for agricultural production that is necessary for indigenous peoples' livelihoods and cultural survival; and

- water for subsistence agriculture, particularly for disadvantaged and marginalized farmers and rural women.

These priorities need to be applied through a contextual assessment to identify potential tensions between, for instance, indigenous peoples' water uses when their cultural survival is not at stake and water uses of other farmers whose subsistence is at stake. In addition, specific individuals within these groups (e.g. rural women) need to receive particular attention. And additional considerations in this balancing exercise arise from other areas of international law. Any prioritization needs to consider environmental sustainability as a precondition for the realization of the universal right to water through the application of an ecosystem approach to water management and reliance on environmental 
impact assessments that integrate human rights, biodiversity and climate change concerns. In that respect, international biodiversity law provides guidance that contributes to specify the procedural obligations arising from the right to water for food and agriculture.

An HRBA to IWRM can provide a useful starting point at the national level to implement the human right to water for food and agriculture. It can support states in consolidating and effectively implementing internationally recognized norms and standards into nationally applicable and enforceable rules. It can further assist in balancing the potentially complex and competing aims of IWRM in order to meet basic standards of living through water management. In turn, HRBA can benefit from the systems-oriented approach of integrated water resource management, as the latter facilitates analysing the entirety of the regulatory framework of water in the context of human rights, including land governance. National law-makers should in particular, consider the need for integrated and adaptive management of water in light of the substantive and procedural dimensions of the human right to water for food and agriculture, including the need for coordination mechanisms between different policy areas and at different levels of governance to assess potential cumulative impacts. National law-makers should also ensure interactions between water rights and land tenure (particularly in light of customary laws of indigenous peoples and local communities), and generally ensure the full and effective participation of these communities, as well as of women, in all aspects of water governance. A transparent and accountable framework for decision-making needs to include environmental and socio-cultural impact assessments that take into account climate change impacts, biodiversity considerations and the rights of indigenous peoples, local communities, and women. Finally, states should ensure flexibility in regulatory approaches to allow for reprioritization in light of changed circumstances and evolving scientific understanding.

The conclusion and implementation of new international agreements should not adversely impact on the right to water for food and agriculture. So new trade and investment treaties should respect existing and potential water uses that contribute to the realization of 
the right to water for food and agriculture. Accordingly, states involved in negotiations of international investment treaties and large-scale land acquisitions should ensure that appropriate procedural guarantees are put in place (access to information, participation in decision-making, prior environmental and socio-cultural assessment, and access to justice), as well as retaining regulatory flexibility to realize the right to water for food and agriculture. In addition, states should discuss, in concluding new trade and investment treaties, as well as development cooperation initiatives, provisions on international cooperation to support the right to water for food and agriculture including with regard to unavoidable effects of climate change on the most vulnerable.

In the case of transboundary water basins, international agreements on shared water management also need to factor in the human right to water for food and agriculture in preventing, reducing and controlling pollution and determining equitable and reasonable use of the watercourse. Equally, the procedural dimensions of the human right to water for food and agriculture should inform the implementation of obligations under these agreements regarding the sharing information and consulting with other states, including sharing the results of any environmental impact assessment. 


\section{References}

\section{Literature}

Ahmad, M. 2017. Promoting Global Water Use Efficiency - Promises and Shortcomings of International Trade Rules. In J. Chaisse, ed. Charting the Water Regulatory Future. Cheltenham, UK, Edward Elgar Publishing.

Akhmouch, A. 2012. Water Governance in Latin America and the Caribbean: A Multi-Level Approach. OECD Regional Development Working Papers, 2012/04, Paris, OECD Publishing. (also available at http://dx.doi. org/10.1787/5k9crzqk3ttj-en).

Alden Wily, L., Dubertret, F., Veit, P., Reytar, K. \& Tagliarino, N. K. 2017. Water Rights on Community Lands: LandMarks Findings from 100 Countries. Land, 6(4): 77-95.

Barritt, E. 2014. Conceptualising Stewardship in Environmental Law. Journal of Environmental Law, 26(1): 1-23.

Boyle, A. 2012. Human Rights and the Environment: Where next? European Journal of International Law, 23(3): 613-642.

Brooks, D. 2007. Human rights to water in North Africa and the Middle East: What is new and what is not; what is important and what is not. International Journal of Water Resources Development, 23(2) 227-241.

Brown Weiss, E. \& Slobodian, A. 2014. Virtual Water, Water Scarcity, and International Trade Law. Journal of International Economic Law, 17(4): 717-737.

Burchi, S. 2005. The interface between customary and statutory water rights - a statutory perspective. FAO Legal Papers Online 45. Rome, FAO. (also available at http://www.fao.org/3/a-bb078e.pdf). 
Cahill, A. 2005. The Human Right to Water - A Right of Unique Status The Legal Status and Normative Content of the Right to Water. The International Journal of Human Rights, 9(3): 389-410.

Chárvarro, J.M. 2015. The Human Right to Water: A Legal Comparative Perspective at the International, Regional and Domestic Level. Cambridge, $\mathrm{UK}$, Intersentia.

Choukroune, L. 2016. Water and sanitation services in international trade and investment law: for a holistic human rights-based approach. In J. Chaisse, ed. The Regulation of the Global Water Services Market. Cambridge, UK, Cambridge University Press.

Clifton, C., Evans, R., Hayes, S., Hirji, R., Puz, G., \& Pizarro, C. 2011. Water and climate change: Impacts on groundwater resources and adaptation options Water Working Notes No. 25. Washington, DC, World Bank. (also available at http://www.groundwatergovernance. org/fileadmin/user_upload/groundwatergovernance/docs/Thematic_ papers/GWG_Thematic_Paper_12.pdf).

Conseil Général de l'alimentaion, de l'agriculture et des Espaces Ruraux (CGAAER). 2012. Water and food security - facing global change: what challenges, what solutions? Paris, CGAAER. (also available at https://www.avsf.org/public/posts/693/water-and-food-securityfacing-global-change-what-challenges-what-solutions.pdf).

Cotula, L. 2008. The property rights challenges if improving access to water for agriculture: Lessons from the Sahel. Journal of Human Development, 9(1): 5-22.

Cotula, L. 2015. Land rights and investment treaties: Exploring the interface. London, IIED. (also available at http://pubs.iied. org/pdfs/12578IIED.pdf).

Cotula, L. 2017. Democracy and International Investment Law. Leiden Journal of International Law, 30(2): 351-382. 
Cotula, L. ed. 2006. Land and water rights in the Sahel. Tenure challenges of improving access to water for agriculture. Issue Paper No. 139. London, International Institute for Environment and Development (IIED). (also available at https://pubs.iied.org/pdfs/12526IIED.pdf).

Craven, M. 1995. The International Covenant on Economic, Social and Cultural Rights, A Perspective on its Development. Oxford, UK, Oxford University Press.

Crawford,S. 2007. The Impact of Rights-based Approaches to Development. UK Interagency Group on Human Rights Based Approaches, Executive Summary. (also available at https://archive.crin.org/en/docs/Inter_ Agency_rba.pdf).

De Schutter, O., Eide, A., Khalfan, A., Orellana, M., Salomon, M.E. \& Seiderman, I. 2012. Commentary to the Maastricht principles on extraterritorial obligations of states in the area of economic, social and cultural rights. Human Rights Quarterly, 34(4): 1084-1169.

Eckstein, G. \& Sindico, F. 2014. The Law of Transboundary Aquifers: Many Ways of Going Forward, but Only One Way of Standing Still. Review of European, Comparative and International Environmental Law, 23(1): $32-42$.

Espa, I. 2015. Export Restrictions on Critical Minerals and Metals. Cambridge, UK, Cambridge University Press.

ETO Consortium. 2011. Maastricht Principles on Extraterritorial Obligations of States in the area of Economic, Social and Cultural Rights. Heidelberg, Germany.

FA0. 2002a. Land tenure and rural development. Land Tenure Studies No. 3. Rome. 50 pp. (also available at http://www.fao.org /3/a-y4307e.pdf). 
FA0. 2002b. Written Contribution to the Day of General Discussion on the General Comment on the Right to Water. Committee on Economic, Social and Cultural Rights (CESCR), Twenty-ninth Session, November 2002, Geneva, Switzerland.

FAO. 2003. Ensuring access to food for all. The role of irrigation in alleviating poverty and improving food security. In FAO ed. Agriculture, Food and Water. Rome. (also available at http://www.fao.org/ docrep/006/Y4683E/y4683e08.htm).

FAO. 2004. Land and Water - The Rights Interface. FAO Legislative Study No. 84. Rome. 120 pp. (also available at http://www.fao.org/3/a-y5692e. pdf).

FA0. 2006a. Demand for Products of Irrigated Agriculture in sub-Saharan Africa. Water Report 31. Rome. 127pp. (also available at http://www.fao. org/tempref/agl/AGLW/docs/wr31e.pdf).

FA0. 2006b. Modern Water Rights Theory and Practice. FAO Legislative Study No. 92. Rome. 116 pp. (also available at http://www.fao.org/3/aa0864e.pdf).

FAO. 2006c. Food security, FAO Policy Briefs No. 2. Rome. 4 pp. (also available at http://www.fao.org/forestry/13128-0e6f36f27e0091 055bec28ebe830f46b3.pdf).

FA0. 2008. The Right to Food and Access to natural Resources, Using Human Rights Arguments and Mechanisms to Improve Resource Access for the Rural Poor, Right to Food Studies by Cotula, L. ed. Rome. 67 pp. (also available at http://www.fao.org/3/k8093e/k8093e.pdf).

FA0. 2009. Law for Water Management: A Guide to Concepts and Effective Approaches. FAO Legislative Study No. 101. Rome. 341 pp. (also available athttp://www.fao.org/3/i1284e/i1284e.pdf).

FAO, ed. 2009. Guide on legislating for the right to food. The right to food, Book 1. Rome. 310 pp. (also available at http://www.fao.org/3/a-i0815e. pdf). 
FA0. 2011. The state of the world's land and water resources for food and agriculture (SOLAW) - Managing systems of risk. Rome, FAO and London, Earthscan. 308 pp. (also available at http://www.fao.org/nr/solaw/ solaw-home/en/).

FA0. 2012. Strategic Evaluation of FAO work on tenure, rights to land and other natural resources - Final evaluation report. Rome. 100 pp. (also available at http://www.fao.org/3/mC957E/mC957E.pdf).

FA0. 2016. Exploring the Concept of Water Tenure. FAO Land and Water Discussion Paper 10. Rome. 73 pp. (also available at http://www.fao. org/3/a-i5435e.pdf).

FA0. 2017. Exploring the human rights-based approach in the context of the implementation and monitoring of the SSF Guidelines. Workshop proceedings, 24 - 26 October 2016, Rome, Italy. FAO Fisheries and Aquaculture Proceedings No. 53. Rome. (also available at http://www. fao.org/3/a-i6933e.pdf).

Fasciglione, M. 2017. Article 28 [Adequate Standard of Living and Social Protection]. In V. Della Fina, R. Cera \& G. Palmisano, eds. The United Nations Convention on the Rights of Persons with Disabilities: A Commentary, pp. 509-539. Cham, Switzerland, Springer International Publishing.

Forman, L., Caraoshi, L., Chapman, A. R., \& Lamprea, E. 2016. Conceptualizing minimum core obligations under the right to health: How should we define and implement the 'morality of the depths. The International Journal of Human Rights, 20(4): 531-548.

Galvão Ferreira, P. 2016. Did the Paris Agreement Fail to Incorporate Human Rights in Operative Provisions? Not If You Consider the 2016 SDGs. CIGI Papers No. 113. Centre for International Governance Innovation. (also available at https://www.cigionline.org/sites/default/files/ documents/Paper\%20no.113.pdf).

Gleick, P. H. 1998. The Human Right to Water. Water Policy, 1(5): 487-503. 
Global Water Partnership (GWP). 2017. The Need for an Integrated Approach. [online]. Stockholm. [Cited 8 December 2017]. http://www. gwp.org/en/About/why/the-need-for-an-integrated-approach/

Hall, R. P. Van Koppen, B. \& Van Houweling, E. 2014. The Human Right to Water: The Importance of Domestic and Productive Water Rights. Science and Engineering Ethics, 20: 849-868.

Hann, C. 1998. Property Relations: Renewing the Anthropological Tradition. Cambridge, UK, Cambridge University Press.

Harris, L.M. \& Roa-García, M.C. 2013. Recent waves of water governance: constitutional reform and resistance to neoliberalization in Latin America (1990-2012). Geoforum, 50: $20-30$.

Headey, D. 2011. Rethinking the global food crisis: The role of trade shocks. Food Policy, 36(2): 136-146.

Hellum, A., Kameri-Mbote, P. \& van Koppen, B. 2015. The Human Right to Water and Sanitation in a Legal Pluralist Landscape: Perspectives of Southern and Eastern African Women. In A. Hellum, P. Kameri-Mbote \& B. van Koppen, eds. Water is Life: Women's Human Rights in National Local Water Governance in Southern and Eastern Africa, pp. 1-31. Harare, Weaver Press.

High Level Panel of Experts (HLPE). 2015. Water for food security and nutrition. A report by the High Level Panel of Experts on Food Security and Nutrition of the Committee on World Food Security. Rome. (also available at http://www.fao.org/3/a-av045e.pdf).

Hoekstra, A.Y. \& Chapagain, A.K. 2007. Water footprints of nations: Water use by people as a function of their consumption pattern. Water Resource Management, 21(1): 25-48.

Hoekstra, A.Y. 2010. The relation between international trade and freshwater scarcity. Staff Working Paper ERSD-2010-05. WTO. Geneva, 
Switzerland. (also available at https://www.wto.org/english/res_e/ reser_e/ersd201005_e.pdf).

Howard, G. \& Bartram, J. 2003. Domestic Water Quantity, Service Level and Health. Geneva, Switzerland, WHO. (also available at http://www. who.int/water_sanitation_health/diseases/WSH0302.pdf).

Hutton, G., \& Haller, L. 2004. Evaluating the costs and benefits of water and sanitation improvements at the global level. Geneva, Switzerland, WHO.

Inter-American Commission on Human Rights (IACHR). 2015. Annual Report 2015, Access to Water in the Americas an Introduction to the Human Right to Water in the Inter-American System. In Annual Reports 2015. Washington, DC, IACHR. (also available at http://www.oas. org/en/iachr/docs/annual/2015/doc-en/InformeAnual2015-cap4Aagua-EN.pdf).

International Labour Organization (ILO). 2009. Indigenous and Tribal Peoples' Rights in Practice: A Guide to ILO Convention No. 169. Geneva, Switzerland, ILO. (also available at http://www.ilo.org/ wcmsp5/groups/public/---ed_norm/---normes/documents/ publication/wcms_106474.pdf).

International Law Commission (ILC). 1994. Draft articles on the law of the non-navigational uses of international watercourses, A/CN.4/L.489.

Jackson, L.A., Pene, C., Martinez-Hommel, M. B., Hofmann C., \& Tamiotti, L. 2014. Water Policy, Agricultural Trade and WTO rules. In P. Martinez-Santos, M.M. Aldaya \& M. Ramon Llamas, eds. Integrated Water Resource Management in the 21st Century: Revisiting the Paradigm, pp. 59-722. Boca Raton, USA, CRC Press.

Jiménez Cisneros, B.E., Oki, T., Arnell, N.W., Benito, G., Cogley, J.G., Döll, P., Jiang, T. \& Mwakalila, S.S. 2014. Freshwater Resources. In C.B. Field, V.R. Barros, D.J. Dokken, K.J. Mach, M.D. Mastrandrea, T.E. Bilir \& M. Chatterjee, eds. Climate Change 2014: Impacts, Adaptation, and Vulnerability. Part A: Global and Sectoral aspects. Contribution of Working 
group II to the Fifth Assessment Report of the Intergovernmental Panel on Climate Change, pp. 229-270. Cambridge, UK and New York, USA, Cambridge University Press.

Joy, K. J., Sangameswaran, P., Latha, A., Dharmadhikary, S., Prassad, M. \& Soma, K. 2012. Life Livelihoods Ecosystem Culture: Entitlement and Allocation of Water for competing uses. Pune, India, Forum for Policy Dialogue on Water Conflicts in India. (also available at http:// re.indiaenvironmentportal.org.in/files/file/Entitlements-andallocation-of-water-for-competing-uses.pdf).

Kurkuk, P. 2004. Customary water laws and practices: Nigeria. [online]. Rome. [Cited 8 December 2017]. http://www.fao.org/fileadmin/ templates/legal/docs/CaseStudy_Nigeria.pdf

Langford, M. \& Woodhouse, M. 2009. Crossfire: There is no human right to water for livelihoods. Waterlines, 28(1): 5-12.

Leb, C. 2012. The right to water in a transboundary context: Emergence of seminal trends." Water International, 37(6): 640-653.

Mayer, B. 2016. Human Rights in the Paris Agreement. Climate Law, 6: 109-117.

McGarry, B. 2018. The Global Pact for the Environment: Freshwater and Economic Law Synergies. Journal of International Economic Law, 21: 745-767.

Meinzen-Dick, R. \& Nkonya, L. 2005. Understanding legal pluralism in water and land rights: lessons from Africa and Asia. In J. Butterworth, B. van Koppen \& I. Juma, eds. International Workshop on African Water Laws: Plural Legislative Frameworks for Rural Water Management in Africa, pp. 109-122. Pretoria, South Africa, International Water Management Institute. (also available at https://assets.publishing.service.gov.uk/ media/57a08c88e5274a31e0001296/R8323-Proceedings.pdf).

Meinzen-Dick, R. \& Nkonya, L. 2007. Understanding Legal Pluralism in Water and Land Rights: Lessons from Africa and Asia. In B. van Koppen, 
M. Giordano \& J. Butterworth, eds. Community-Based Water Law and Water Resources Management Reform in Developing Countries, pp. 12-27. Oxford, UK, CAB International.

Meinzen-Dick, R. 2014. Property Rights and Sustainable Irrigation. A Developing Country Perspective. Water Management, 145: 23-31.

Morgera, E. \& Tsioumani, E. 2010. The Evolution of Benefit Sharing. Review of European Community and International Environmental Law, 19(2): 150-173.

Morgera, E. 2016. The Need for an International Legal Concept of Fair and Equitable Benefit-sharing. European Journal of International Law, 27(2): 353-383.

Morgera, E. 2017. The Ecosystem Approach and the Precautionary Principle. In E. Morgera \& J. Razzaque, eds. Biodiversity and Nature Protection Law, pp. 70-80. Cheltenham, UK, Edward Elgar Publishing.

Morgera, E. 2019. Under the radar: the role of fair and equitable benefitsharing in protecting and realising human rights connected to natural resources. The International Journal of Human Rights, 23(7): 1098-1139.

Moynihan, R. 2020. Transboundary Freshwater Ecosystems in International Law: The Role and Impact of the UNECE Environmental Regime. Cambridge, UK, Cambridge University Press.

Moynihan, R. \& Magsig, B.o. 2014. The Rising Role of Regional Approaches to International Water Law: Lessons from the UNECE Water Regime and Himalayan Asia for Strengthening Transboundary Water Cooperation. RECIEL, 23(1): 43-58.

Muller, M. \& Bellmann, C. 2016. Trade and Water: How Might Trade Policy Contribute to Sustainable Water Management? Geneva, Switzerland, International Centre for Trade and Sustainable Development (also available at https://www.ictsd.org/sites/default/files/research/trade_ and_water.pdf). 
Nickel, J.W. 2008. Rethinking indivisibility: Towards a theory of supporting relations between human rights. Human Rights Quarterly, 30(4): 984-1001.

Olmos Giupponi, M.B. \& Paz, M.C. 2015. The implementation of the human right to water in Argentina and Colombia. Anuario Mexicano de Derecho Inernacional, 15(1): 323-352.

Ostrom, E. 1990. Governing the Commons: The Evolution of Institutions for Collective Action. Cambridge, UK, Cambridge University Press.

Pardy, B. 2003. Changing nature: The Myth of the Inevitability of Ecosystem Management. Pace Environmental Law Review, 20: 675-692.

Pavoini, R. 2010. Mutual Supportiveness as a Principle of Interpretation and Law-Making: A Watershed for the 'WTO-and-Competing Regimes' Debate? European Journal of International Law, 21: 649-679.

Popovic, N.A.F. 1996. In Pursuit of Environmental Human Rights. Columbia Human Rights Law Review, 27: 487-603.

Quane, H. 2012. A further dimension to the interdependence and indivisibility of human rights: Recent developments concerning the rights of indigenous peoples. Harvard Human Rights Journal, 25: 49-83.

Robbie, J. 2015. Private Water Rights. Edinburgh, UK, Edinburgh Legal Education Trust.

Salomon, M.E. \& Seiderman, I. 2012. Human Rights Norms for a Globalized World: The Maastricht Principles on Extraterritorial Obligations of States in the area of Economic, Social and Cultural Rights. Global Policy, 3: 458-462.

Scanlon, J., Cassar, A. \& Nemes, N. 2004. Water as a Human Right? IUCN Environmental Policy and Law Paper No. 51. Gland, Switzerland \& Cambridge, UK, IUCN. 
Schlager, E. \& Ostrom, E. 1992. Property Rights Regime and Natural Resources: A Conceptual Analysis. Land Economics, 68(3): 249-262.

Schmitz, H.P. 2012. A Human Rights-Based Approach (HRBA) in Practice: Evaluating NGO Development Efforts. Polity, 44(4): 523-541.

Searchinger, T., Edwards, R., Mulligan, D., Heimlich, R. \& Plevin, R. 2015. Do biofuel policies seek to cut emissions by cutting food? Science, 347(6229): 1420-1422.

Siebert, S., Burke, J., Faures, J.M., Frenken, K., Hoogeveen, J., Döll, P. \& Portmann, F. T. 2010. Groundwater use for irrigation - a global inventory. Hydrology and Earth System Sciences, 14: 1863-1880. (also available at http://www.fao.org/docrep/013/al816e/al816e00.pdf).

Skinner, J. \& Cotula, L. 2011. Are land deals driving 'water grabs'? London, UK, IIED. (also available at http://pubs.iied.org/17102IIED/).

Stern, S. 2007. Stern Review on the Economics of Climate Change. Cambridge, UK, Cambridge University Press.

Temmerman, F. 2017. Trade in Water Under International Law: Bulk Fresh Water, Irrigation Subsidies and Virtual Water. Chelternham, UK, Edward Elgar Publishing.

Turrini, P. 2015. Water, From One State to Another: The Wavering Legal Status of Water and its Export in Bulk Under International Trade Law. Trade, Law \& Development, 7(2): 300-355.

UN Committee on Economic, Social and Cultural Rights (CESCR). 1999. General Comment No. 12: The Right to Adequate Food (Article 11), E/C.12/1999/5.

CESCR. 2000. General Comment No. 14: The Right to the Highest Attainable Standard of Health (Article 12), E/C.12/2000/4.

CESCR. 2002a. General Comment No. 15: The Right to Water, E/C.12/2002/11. 
CESCR. 2002b. Summary Record of the First Part (Public) of the 50th Meeting, E/C.12/2002/SR.50.

CESCR. 2007. General Comment No. 19: The right to social security (Article 9), E/C.12/GC/19.

CESCR. 2017. General Comment No. 24: State obligations under the International Covenant on Economic, Social and Cultural Rights in the context of business activities, E/C.12/GC/24.

\section{United Nations Conference on Trade and Development (UNCTAD).} 2018. World Investment Report. Investment and New Industrial Policies. Geneva, Switzerland. (also available at https://unctad.org/en/ PublicationsLibrary/wir2018_en.pdf).

UN Development Group (UNDG). 2003. The Human Rights Based Approach to Development Cooperation: Towards a Common Understanding Among UN Agencies. (also available at https://undg. org/wp-content/uploads/2016/09/6959-The_Human_Rights_Based_ Approach_to_Development_Cooperation_Towards_a_Common Understanding_among_UN.pdf).

UN Development Programme (UNDP). 2007. Human Development Report 2007/2008. Fighting climate change: Human Solidarity in a divided world. New York, USA.

UN Economic Commission for Europe (UNECE). 2013. UNECE Water Convention goes global. Press release, 6 February 2013. (also available at http://www.unece.org/index.php?id=32154).

United Nations Environment Programme (UNEP). 2012. The UN Water Status Report on the Application of Integrated Approaches to Water Resources Management. Nairobi, UNEP. (also available at http://www. un.org/waterforlifedecade/pdf/un_water_status_report_2012.pdf).

UN General Assembly (UNGA). 2001. Preliminary report of the Special Rapporteur of the Commission on Human Rights on the right to food. Jean Ziegler, A/56/210. 
UNGA. 2015. Interim report of the Special Rapporteur on the right to food. Hilal Elver, A/70/287.

UNGA. 2016a. Report of the Special Rapporteur on the human right to safe drinking water and sanitation. Catarina de Albuquerque, A/71/302.

UNGA. 2017. Report of the Special Rapporteur on the human rights to safe drinking water and sanitation. Catarina de Albuquerque, A/72/127.

UN Human Rights Committee (HRCtte). 2004. General Comment No. 31: Nature of the General Legal Obligation on States Parties to the Covenant, CCPR/C/21/Rev.1/Add.13.

UN Human Rights Council (HRC). 2003. The right to food: Report submitted by the Special Rapporteur on the right to food, Jean Ziegler, in accordance with Commission on Human Rights resolution 2002/25, E/ CN.4/2003/54.

HRC. 2007. Report of the United Nations High Commissioner for Human Rights on the scope and content of the relevant human rights obligations related to equitable access to safe drinking water and sanitation under international human rights instruments, A/HRC/6/3.

HRC. 2010. Report submitted by the Special Rapporteur on the right to food. Olivier De Schutter, A/HRC/16/49.

HRC. 2011. Report of the Special Rapporteur on the human right to safe drinking water and sanitation. Catarina de Albuquerque, A/HRC/18/33.

HRC. 2013a. Report of the Independent Expert on the issue of human rights obligations relating to the enjoyment of a safe, clean, healthy and sustainable environment. John $\mathrm{H}$. Knox, A/HRC/25/53.

HRC. 2013b. Report of the Special Rapporteur on the human right to safe drinking water and sanitation. Catarina de Albuquerque, A/HRC/24/44.

HRC. 2013c. Human Right to Safe Drinking Water and Sanitation, A/68/264. 
HRC. 2016. Report of the Special Rapporteur on the Issue of Human Rights Obligations Relating to the Enjoyment of a Safe, Clean, Healthy and Sustainable Environment: Climate Change Report. John Knox, $\mathrm{A} / \mathrm{RC} / 31 / 52$.

HRC. 2017. Report of the Special Rapporteur on the issue of human rights obligations relating to the enjoyment of a safe, clean, healthy and sustainable environment. John Knox, A/HRC/34/49.

UN Office of the High Commissioner for Human Rights (OHCHR). 2002. The Right to Water. Human Rights Factsheet No. 35. (also available at http://www.ohchr.org/Documents/Publications/FactSheet35en.pdf).

UN Secretary General. 2012. Secretary-General Ban Ki-moon's message for World Water Day, to be observed on 22 March. SG/SM/14163, ENV/ DEV/1262, OBV/1075. [Online]. New York, USA, UN. (also available at https://www.un.org/press/en/2012/sgsm14163.doc.htm).

van Koppen, B. 2017. Customary Water Rights and Legal Pluralism. In Rieu-Clarke, A., Allan, A. \& Hendry, S. eds. Routledge Handbook of Water Law and Policy. Abingdon, UK, Routledge.

van Koppen, B. \& Schreiner, B. 2018. A Hybrid Approach to Decolonize Formal Water Law in Africa. IWMI Research Report 173. Colombo, International Water Management Institute (IWMI). (also available at http://www.iwmi.cgiar.org/Publications/IWMI_Research_Reports/ $\mathrm{PDF} /$ pub173/rr173.pdf).

von Benda-Beckmann, F. 1995. Anthropological Approaches to Property Law and Economics. European Journal of Law and Economics, 2(4): 309-336.

Water Governance Facility (WGF). 2012. Human Rights-Based Approaches and Managing Water Resources: Exploring the Potential for Enhancing Development Outcomes. WGF Report No 1. Stockholm, SIWI. 
WaterLex, UNDP-SIWI Water Governance Facility, REDICA \& CapNet. 2017. Human rights-based approach to integrated water resources management: training manual and facilitator's guide. Rio de Janeiro, Brazil, Cap-Net. (also available at http://watergovernance.org/ resources/human-rights-based-approach-integrated-water-resourcesmanagement-training-manual-facilitators-guide/).

WaterLex \& WASH United. 2014. The Human Rights to Water and Sanitation in Courts Worldwide, A Selection of National, Regional and International Case Law. Geneva, Switzerland, WaterLex \& WASH United. (also available at http://hrbaportal.org/wp-content/files/ Human-rights-to-water-and-sanitation-in-courts_WEB_2015.pdf).

World Health Organization (WHO) \& United Nations International Children's Emergency Fund (UNICEF). 2017. Progress on drinking water, sanitation and hygiene: 2017 update and SDG baselines. Geneva, Switzerland, WHO \& UNICEF.

World Water Assessment Programme (WWAP). 2006. Water, a shared responsibility, UN World Water Development Report 2. Paris \& New York, USA, Berghan Books. (also available at http://www.unwater.org/ publications/water-shared-responsibility/).

WWAP. 2012. The United Nations World Water Development Report 4: Managing Water under Uncertainty and Risk. Paris, UNESCO.

Williams, Z. 2017. Tanzania Faces Arbitration over Failed Large-scale Agricultural Investment; Project Had Engendered Opposition from Locals who Were to be Displaced, and also in Relation to Wildlife Impacts. Investment Arbitration Reporter. (also available at https://www. iareporter.com/articles/tanzania-faces-arbitration-over-failed-largescale-agricultural-investment-project-had-engendered-oppositionfrom-locals-who-were-to-be-displaced-and-also-in-relation-to-wildlifeimpacts). 
Windfuhr, M. 2003. Water for Food: A Human Rights Obligation - How States Manage Conflicts Between the Human Right to Water and the Human Right to Adequate Food. Berlin, German Institute for Human Rights. (also available at http://www.institut-fuer-menschenrechte.de/uploads/tx_ commerce/Study_Water_for_Food_a_Human_Rights_Obligation.pdf).

Winkler, I.T. 2012. The Human Right to Water: Significance, Legal Status and Implications for Water allocation. Oxford, UK, Hart Publishing.

Winkler, I.T. 2017. Water for producing food for basic consumption: Guaranteed by the right to water or food. In M. Langford, \& A. Russel, eds. The Right to Water: Theory, Practice and Prospects. Cambridge, UK, Cambridge University Press.

World Trade Organization (WT0). 2010. World Trade Report 2010: Trends in Natural Resources. Geneva, Switzerland, WTO. (also available at https://www.wto.org/english/res_e/booksp_e/anrep_e/world_trade_ report10_e.pdf).

\section{Legally-binding international instruments}

Agreement on Agriculture (AoA). World Trade Organization (WTO), 1995. (also available at https://www.wto.org/english/docs_e/legal_e/14-ag. pdf).

Agreement on Declaration of Principles on the Grand Ethiopian Renaissance Dam Project, Khartoum, 23 March 2015. (also available at https:// www.internationalwaterlaw.org/documents/regionaldocs/Final_Nile_ Agreement_23_March_2015.pdf).

Agreement on Technical Barriers to Trade (TBT).WTO, 1995 (also available at https://www.wto.org/english/docs_e/legal_e/17-tbt_e.htm).

Agreement on the Nile River Basin Cooperative Framework, Entebbe, 2010. (also available at https://www.nilebasin.org/images/docs/CFA\%20 -\%20English\%20\%20FrenchVersion.pdf). 
Comprehensive Economic and Trade Agreement (CETA), between Canada and the European Union, 30 October 2016. (also available at https:// eur-lex.europa.eu/legal-content/EN/TXT/?uri=CELEX:22017A0114 (01)).

Convention Concerning the Protection of the World Cultural and Natural Heritage, UN Education, Scientific and Cultural Organisation (UNESCO), adopted 17 December 1972. (also available at http://whc.unesco.org/ archive/convention-en.pdf).

Convention in International Trade in Endangered Species of Wild Fauna and Flora (CITES), 3 March 1973, amended 1979 and 1983 (also available at https://www.cites.org/eng/disc/text.php).

Convention on Biological Diversity (CBD), adopted in Nairobi, 22 May 1992, and open for signature in Rio de Janeiro 5, June 1992. (also available at https://www.cbd.int/doc/legal/cbd-en.pdf).

Convention on the Conservation of Migratory Species (CMS), 23 June 1979. (also available at https://www.cms.int/sites/default/files/instrument/ CMS-text.en_.PDF).

Convention on the Elimination of All Forms of Discrimination Against Women (CEDAW). United Nations General Assembly (UNGA), A/Res/34/180, adopted 18 December 1979. (also available at https:// www.ohchr.org/EN/ProfessionalInterest/Pages/CEDAW.aspx).

Convention on the Law of Non-Navigational Uses of International Watercourses (UN Watercourses Convention), 21 May 1997. (also available at http://legal.un.org/ilc/texts/instruments/english/ conventions/8_3_1997.pdf).

Convention on the Rights of the Child (CRC). UNGA Resolution 44/25, adopted 20 November 1989. (also available at https:// www.ohchr.org/EN/ProfessionalInterest/Pages/CRC.aspx). 
Convention on Wetlands of International Importance (Ramsar), adopted in Ramsar, 2 February 1971. (also available at https://www.ramsar.org/ sites/default/files/documents/library/current_convention_text_e.pdf).

General Agreement on Tariffs and Trade (GATT). WTO, 1994. (also available at https://www.wto.org/nglish/docs_e/legal_e/06-gatt_e.htm).

General Agreement on Trade in Services (GATS). WTO, 1995 (also available at https://www.wto.org/english/docs_e/legal_e/26-gats.pdf).

Indigenous and Tribal Peoples Convention, 1989 (No. 169). International Labour Organization (ILO), adopted in Geneva, 27 June 1989. (also available at https://www.ilo.org/dyn/normlex/ en/f?p=NORMLEXPUB:12100:0::NO::P12100_ILO_CODE:C169).

International Convention for the Regulation of Whaling, 2 December 1946 (also available at https://iwc.int/convention).

International Covenant on Economic, Social and Cultural Right (ICESCR). UNGA resolution 2200A (XXI), adopted 16 December 1966. (also available at https://www.ohchr.org/EN/Professional Interest/Pages/CESCR.aspx).

International Plant Protection Convention 1951. FAO Conference, new revised text adopted in Rome, 1997. (also available at https://www.ippc. int/en/core-activities/governance/convention-text/, https://www.ippc. int/static/media/files/publications/en/2013/06/06/1329129099_ ippc_2011-12-01_reformatted.pdf).

International Treaty on Plant Genetic Resources for Food and Agriculture. FAO Conference, adopted in Rome, 3 November 2001. (also available at http://www.fao.org/3/a-i0510e.pdf).

Paris Agreement, United Nations Framework Convention on Climate Change (Paris Agreement), FCCC/CP/2015/L.9/Rev.1., adopted in Paris, 12 December 2015. (also available at https://unfccc.int/ sites/default/files/english_paris_agreement.pdf). 
Protocol for Sustainable Development of the Lake Victoria Basin, 29 November 2003. (also available at http://extwprlegs1.fao.org/docs/ pdf/mul41042.pdf).

Protocol on Water and Health to the 1992 Convention on the Protection and Use of Transboundary Watercourses and International Lakes, 17 June 1999. (also available at http://www.unece.org/fileadmin/DAM/env/ documents/2000/wat/mp.wat.2000.1.e.pdf).

Revised Protocol on Shared Watercourses in the Southern African Development Community (SADC), 28 August 1995, revised 7 August 2000. (also available at https://www.sadc.int/files/3413/ 6698/6218/Revised_Protocol_on_Shared_Watercourses_-_2000_-English.pdf).

Statute of the Interstate Commission for Water Coordination of Central Asia, 5 December 1992. (also available at http://www.icwc-aral.uz/ statute4.htm).

Convention on the Protection and Use of Transboundary Watercourses and International Lakes (UNECE Water Convention). UNECE, adopted in Helsinki, 17 March 1992. (also available at http://www.unece.org/env/ water/text/text.html).

United Nations Framework Convention on Climate Change (UNFCCC), adopted in New York, 9 May 1992, and opened for signature in Rio de Janeiro, 4 June 1992. (also available at https://unfccc.int/ resource/docs/convkp/conveng.pdf).

Universal Declaration of Human Rights (UDHR). UNGA, A/RES/217 A (III), 10 December 1948. (also available at https://www.un.org/en/ ga/search/view_doc.asp?symbol=A/RES/217(III)). 


\section{Non-legally-binding international instruments}

Agenda 21 of the Rio Declaration on Environment and Development. UNGA, A/CONF.151/26, June 1992. (also available at https:// sustainabledevelopment.un.org/content/documents/Agenda21.pdf).

Akwé: Kon Voluntary guidelines for the conduct of cultural, environmental and social impact assessments regarding developments proposed to take place on, or which are likely to impact on, sacred sites and on lands and waters traditionally occupied or used by indigenous and local communities. CBD Conference of the Parties, endorsed 2004. (also available at https:// www.cbd.int/doc/publications/akwe-brochure-en.pdf).

Basic Principles and Guidelines on the Right to a Remedy and Reparation for Victims of Gross Violations of International Human Rights Law and Serious Violations of International Humanitarian Law. UNGA, A/ RES/60/147, 2006. (also available at https://www.ohchr.org/EN/ ProfessionalInterest/Pages/RemedyAndReparation.aspx).

Decision IV/4. Status and trends of the biological diversity of inland water ecosystems and options for conservation and sustainable use. CBD Conference of the Parties, UNEP/CBD/COP/DEC/IV/4, 1998. (also available at https://www.cbd.int/decisions/cop/4/9).

Decision V/6. Ecosystem approach. CBD Conference of the Parties (COP), UNEP/CBD/COP/DEC/V/6, 2000. (also available at https://www.cbd. int/doc/decisions/COP-06-dec-en.pdf).

Decision VII/16. Article 8(j) and related provisions. CBD Conference of the Parties, UNEP/CBD/COP/DEC/VII/16, 2004. (also available at https:// www.cbd.int/doc/decisions/cop-07/cop-07-dec-16-en.pdf).

Decision VII/4. Biological diversity of inland water ecosystems. CBD Conference of the Parties, UNEP/CBD/COP/DEC/VII/4, 2004. (also available at https://www.cbd.int/doc/decisions/cop-07/cop-07-dec04-en.pdf). 
Decision $X / 28$. Inland waters biodiversity. CBD Conference of the Parties, $\mathrm{UNEP} / \mathrm{CBD} / \mathrm{COP} / \mathrm{DEC} / \mathrm{X} / 28,2010$. (also available at https://www.cbd. int/doc/decisions/cop-10/cop-10-dec-28-en.pdf).

Decision $X / 33$. Biodiversity and climate change. CBD Conference of the Parties, UNEP/CBD/COP/DEC/X/33, 2010. (also available at https:// www.cbd.int/doc/decisions/cop-10/cop-10-dec-33-en.pdf).

Decision X/34. Agricultural biodiversity. CBD Conference of the Parties, UNEP/CBD/COP/DEC/X/34, 2010. (also available at https://www.cbd. int/doc/decisions/cop-10/cop-10-dec-34-en.pdf).

Decision XII/12. Article 8(j) and related provisions. CBD Conference of the Parties, UNEP/CBD/COP/DEC/XII/12, 2014. (also available at https:// www.cbd.int/doc/decisions/cop-12/cop-12-dec-12-en.pdf).

Decision XIII/3. Strategic actions to enhance the implementation of the Strategic Plan for Biodiversity 2011-2020 and the achievement of the Aichi Biodiversity Targets, including with respect to mainstreaming and the integration of biodiversity within and across sectors. CBD Conference of the Parties, CBD/COP/DEC/XIII/3, 2016. (also available at https://www. cbd.int/doc/decisions/cop-13/cop-13-dec-03-en.pdf).

Decision XIII/5. Ecosystem restoration: short-term action plan. CBD Conference of the Parties, CBD/COP/DEC/XIII/5, 2016. (also available at https://www.cbd.int/doc/decisions/cop-13/cop-13-dec-05-en.pdf).

Human rights and access to safe drinking water and sanitation. HRC, A/ HRC/RES/15/9, 2010. (also available at https://undocs.org/A/HRC/ RES/15/9).

Human rights and access to safe drinking water and sanitation. HRC, A/HRC/RES/7/22, 2008. (also available at https://ap.ohchr.org/ documents/E/HRC/resolutions/A_HRC_RES_7_22.pdf).

Human rights and climate change. HRC, A/HRC/RES/18/22, 2011. (also available at https://undocs.org/en/A/HRC/RES/18/22). 
Memorandum of Understanding for the Establishment of a Consultation Mechanism for the Integrated Management of the Water Resources of the Iullemeden, Taoudeni/Tanezrouft Aquifer Systems (ITAS). Council of Ministers of Gicresait Project, 28 March 2014. (also available at http://extwprlegs1.fao.org/docs/pdf/mul135180.pdf).

Model Provisions on Transboundary Groundwaters. UN Economic Commission for Europe (UNECE), 2012. (also available at https:// www.unece.org/fileadmin/DAM/env/water/publications/WAT_model_ provisions/ece_mp.wat_40_eng.pdf).

OECD Principles on Water Governance. OECD Regional Development Policy Committee, 11 May 2015. (also available at https://www.oecd. org/governance/oecd-principles-on-water-governance.htm).

Policy recommendation on water for food security. Committee on World Food Security (CFS), 42nd session, 2015. (also available at http://www. fao.org/3/a-av046e.pdf).

Principles for Responsible Investment in Agriculture and Food Systems. CFS, endorsed in Rome, 15 October 2014. (also available at http://www. fao.org/3/a-au866e.pdf).

Recommendation C.3.3. Wise use of wetlands (revised). Ramsar Conference of the Contracting Parties, 1987. (also available at https://www.ramsar. org/sites/default/files/documents/library/key_rec_3.03e.pdf).

Report of the United Nations Water Conference, Mar del Plata, 14-25 March 1977. United Nations, E/CONF.70/29, 1977. (also available at https:// undocs.org/en/E/CONF.70/29).

Resolution VIII.1. Guidelines for the allocation and management of water for maintaining the ecological functions of wetlands. Ramsar Conference of the Contracting Parties (COP), 2002. (also available at https://www. ramsar.org/sites/default/files/documents/pdf/res/key_res_viii_01_e. pdf). 
Resolution X.15. Describing the ecological character of wetlands, and data needs and formats for core inventory: harmonized scientific and technical guidance. Ramsar Conference of the Contracting Parties, 2008. (also available at https://www.ramsar.org/sites/default/ files/documents/pdf/res/key_res_x_15_e.pdf).

Resolution X.17. Environmental Impact Assessment and Strategic Environmental Assessment: updated scientific and technical guidance. Ramsar Conference of the Contracting Parties, 2008. (also available at https://www.ramsar.org/sites/default/files/docu ments/pdf/res/key_res_x_17_e.pdf).

Resolution X.31. Enhancing biodiversity in rice paddies as wetland systems. Ramsar Conference of the Contracting Parties, 2008. (also available at https://www.ramsar.org/sites/default/files/documents/pdf/res/key_ res_x_31_e.pdf).

Resolution XII.2. The Ramsar Strategic Plan 2016-2024. Ramsar Convention, Conference of the Contracting Parties, 2015. (also available at https://www.ramsar.org/sites/default/files/documents/library/ cop12_res02_strategic_plan_e_0.pdf).

The Dublin Statement on Water and Sustainable Development. International Conference on Water and the Environment (ICWE), adopted in Dublin, 31 January 1992. (also available at https:// public.wmo.int/en).

The human right to water and sanitation. UNGA, A/RES/64/292, 2010. (also available at https://documents-dds-ny.un.org/doc/ UNDOC/GEN/N09/479/35/PDF/N0947935.pdf?OpenElement).

The human rights to safe drinking water and sanitation. UNGA, A/ RES/70/169, 201 5. (also available at https://documents-dds-ny.un.org/ doc/UNDOC/GEN/N15/442/72/PDF/N1544272.pdf?OpenElement).

The law of transboundary aquifers, UNGA, A/RES/63/124, adopted 11 December 2008. (also available at https://undocs.org/en/A/ RES/68/118). 
The right to food. $\mathrm{HRC}, \mathrm{A} / \mathrm{HRC} / \mathrm{RES} / 31 / 10,2016$. (also available at https://documents-dds-ny.un.org/doc/UNDOC/GEN/G16/083/41/ PDF/G1608341.pdf?OpenElement).

Transforming Our World: The 2030 Agenda for Sustainable Development. UNGA, A/RES/70/1, adopted 2015. (also available at http://www. un.org/ga/search/view_doc.asp?symbol=A/RES/70/1\&Lang=E).

United Nations Declaration on the Rights of Indigenous Peoples (UNDRIP), UNGA, A/RES/61/295, 13 September 2007. (also available at https:// www.un.org/development/desa/indigenouspeoples/declaration-onthe-rights-of-indigenous-peoples.html).

United Nations Declaration on the Rights of Peasants and Other People Working in Rural Areas. UNGA, A/RES/73/165, 17 December 2018. (also available at https://undocs.org/en/A/RES/73/165).

United Nations Guiding Principles on Business and Human Rights: Implementing the United Nations "Protect, Respect and Remedy" Framework. HRC, A/HRC/RES/17/4, 16 June 2011. (also available at https://www.ohchr.org/Documents/Publications/GuidingPrinciples BusinessHR_EN.pdf).

Vienna Declaration and Programme of Action. UNGA, A/CONF.157/23, 12 July 1993. (also available at https://www.ohchr.org/en/ professionalinterest/pages/vienna.aspx).

Voluntary Guidelines on the Responsible Governance of Tenure of Land, Fisheries and Forests in the Context of National Food Security (VGGT). CFS, endorsed 11 May 2012. (also available at http://www.fao.org/ docrep/016/i2801e/i2801e.pdf).

Voluntary Guidelines to Support the Progressive Realization of the Right to Adequate Food in the Context of National Food Security (RTFG). FAO Council, adopted in Rome, November 2004, Rome. (also available at http://www.fao.org/3/a-y7937e.pdf). 


\section{National legislation}

Armenia. Water Code of the Republic of Armenia (2002).

Bolivia (Plurinational State of). Ley № 1333 - Ley del Medio Ambiente / Law on the Environment (1992).

Bolivia. (Plurinational State of). Decreto Supremo № 24.176 Reglamento de Prevención y Control Ambiental / General Regulation of Environmental Management (1995).

Bolivia (Plurinational State of). Nueva Constitución Política Del Estado / New Political Constitution of the State (2009).

Ethiopia. Constitution of the Federal Democratic Republic of Ethiopia (1995).

European Union. Directive 2000/60/EC of the European Parliament and of the Council of 23 October 2000 establishing a framework for Community action in the field of water policy (2000).

France. Loi no 2006-1772 du 30 décembre 2006 sur l'eau et les milieux aquatiques / Law on Water and Aquatic Environments (2006).

Greece. Law on Water Protection and Management (2003).

India. Constitution of India (1949, amended 2012).

Kazakhstan. Water Code (No. 481 of 2003).

Kenya. Water Resource Management Rules (L.N. No. 171 of 2007).

Kenya. Water Act (No. 43 of 2016).

Malawi. Water Resources Act (No. 2 of 2013).

Namibia. Water Resources Management Act (2004).

Niger. Loi portant régime de l'eau (1993). 
Nigeria. Water Resources Decree (No. 101 of 1993).

Papua New Guinea. Water Resources Act (1982, repealed by Environmental Act No. 64 of 2000).

South Africa. Constitution of the Republic of South Africa (1996).

South Africa. Water Services Act (Act No. 108 of 1997).

South Africa. National Water Act (1998).

Spain. Real Decreto Legislativo 1/2001, de 20 de julio, por el que se aprueba el texto refundido de la Ley de Aguas / Royal Legislative Decree Approving the Consolidated Text of Water Law (2001).

The Gambia. Constitution of the Republic of The Gambia (1997).

United Kingdom of Great Britain and Northern Ireland (Scotland). Water Environment and Water Services (Scotland) Act (Asp 3 of 2003).

United Kingdom of Great Britain and Northern Ireland (Scotland). Water Environment (Controlled Activities) (Scotland) Regulations (S.S.I No. 209 of 2011).

Uruguay. Constitución De La República / Constitution of the Republic (1996, amended 2004).

Zambia. Constitution of Zambia (1991, amended 2016).

\section{International case law}

Brazil - Measures Affecting Imports of Retreated Tyres, Report of the Appellate Body, WT/DS332/AB/R (WTO 3 December 2007).

China - Measures Related to the Exportation of Various Raw Materials, Report of the Appellate Body, WT/DS394/AB/R, WT/DS395/AB/R (WTO 30 January 2012). 
EcoDevelopment in Europe $A B$ \& others $v$ United Republic of Tanzania, ICSID Case No. ARB/17/33 (ICSID ongoing).

Gabcíkovo-Nagymoros Project Case (Hungary v Slovakia), ICJ No. 92 (ICJ 1997).

Pulp Mills on the River Uruguay (Argentina v Uruguay), Judgement, International Court of Justice (ICJ) Reports 2010 (ICJ 2010).

United States of America - Import Prohibitions on Certain Shrimp and Shrimp Products, Report of the Appellate Body, WT/DS58/AB/R (WTO 12 October 1998).

Urbaser S.A. and Consorcio de Aguas Bilbao Bizkaia, Bilbao Biskaia Ur Partzuergoa v Argentina, ICSID Case No. ARB/07/26, award dated 8 December 2016 (ICSID 2016).

\section{National case law}

\section{Argentina}

Asociación Civil por la Igualdad y la Justicia c/ Gobierno de la Ciudad de Buenos Aires Cámara de Apelaciones en lo Contencioso Administrativo y Tributario (Ciudad Autónoma de Buenos Aires), (18 July 2007).

Defensor del Pueblo de la Nación c/ Estado Nacional y Provincia del Chaco, D. 587. XLIII (Suprema Corte 2007).

\section{Colombia}

Flor Enid Jimenez de Correa v Empresas Públicas de Medellin, C.C. T-270/07 (2007)

\section{Ecuador}

Caso $n^{\circ}$ 0006-10-EE, Sentencia $N^{\circ}$ 0010-10-SEE-CC (Corte Constitucional 8 April 2010). 


\section{India}

Subhash Kumar v State of Bihar, AIR 1991 SC 420 (Supreme Court of India 1991).

Vishala Kochi Kudivella Samrakshana Samithi v State of Kerala, 2006 (1) KLT 919 (High Court of Kerala 2006).

\section{South Africa}

City of Cape Town v Strümpher, ZASCA 54 (2012).

Government of the Republic of South Africa and Others $v$ Grootboom and Others, CCT11/00, [2000] ZACC (Constitutional Court 2000).

Residents of Bon Vista Mansions v Southern Metropolitan Local Council, (6) BCLR 625 (W) (2002).

\section{United States of America}

Pilchen v City of Auburn, NY, 728 F.Supp.2d 192 (2010). 
The right to water emerged in the Noughties, primarily as the right to domestic water for drinking, washing and cooking, and was closely related to the right to sanitation, both of which are seen as a component of the right to an adequate standard of living.

This study examines the question of the right to water for food and agriculture and asks whether such a right can be found in the right to water, or whether it is more appropriate to examine the right to adequate food for that purpose. Seeking inspiration from the right to adequate food and from other fields of international law, the study explores the content of the right to water for food and agriculture and then considers its implications for water law. Recognizing a human right to water, for drinking and household needs as well as for growing food, has implications for water allocation and sets limits to the extent that water can be allocated for other uses. In addition, it entails the respect for procedural rights and attention to important principles, such as the principle of non-discrimination and the rights of indigenous peoples. 